Portland State University

PDXScholar

Fall 12-11-2012

\title{
Characterization of the Red Bluff Landslide, Greater Cascade Landslide Complex, Columbia River Gorge, Washington
}

James Robert Randall

Portland State University

Follow this and additional works at: https://pdxscholar.library.pdx.edu/open_access_etds

Part of the Geology Commons

Let us know how access to this document benefits you.

\section{Recommended Citation}

Randall, James Robert, "Characterization of the Red Bluff Landslide, Greater Cascade Landslide Complex, Columbia River Gorge, Washington" (2012). Dissertations and Theses. Paper 898.

https://doi.org/10.15760/etd.898

This Thesis is brought to you for free and open access. It has been accepted for inclusion in Dissertations and Theses by an authorized administrator of PDXScholar. Please contact us if we can make this document more accessible: pdxscholar@pdx.edu. 
Characterization of the Red Bluff Landslide,

Greater Cascade Landslide Complex,

Columbia River Gorge, Washington

by

James Robert Randall

A thesis submitted in partial fulfillment of the requirements for the degree of

Master of Science

in

Geology

Thesis Committee:

Scott F. Burns, Chair

Andrew G. Fountain

Jim O'Connor

Portland State University

(C)2012 
(C) 2012 James Robert Randall 


\section{Abstract}

Located in the Columbia River Gorge, The Red Bluff Landslide $\left(18.8 \mathrm{~km}^{2}\right)$ is one of four large landslides that make up the Cascade Landslide Complex. In its current form, the Red Bluff Landslide is a post-Missoula Flood feature made up of two components: an active upper lobe $\left(8.6 \mathrm{~km}^{2}\right)$ that is translational, creeping to the south at $25 \mathrm{~cm} / \mathrm{yr}$ and spreading laterally to the east at $6 \mathrm{~cm} / \mathrm{yr}$ over a semi-fixed portion $\left(10.2 \mathrm{~km}^{2}\right)$ of the Red Bluff Landslide area that has been "smoothed" by Missoula Floods. The upper active lobe is the landslide debris accumulated since Missoula Flood time ( 15,000 yr. BP). Five separate collapse events have been identified and rock failures along the main scarp headwalls continue. Two rock avalanches on the Red Bluff Landslide were mapped. The Old Greenleaf Basin Rock Avalanche is estimated to have occurred 100 to 150 years ago, represents the fifth collapse event on the Red Bluff Landslide, and covers an area of $200,000 \mathrm{~m}^{2}$. It has a volume of 4.2 million $\mathrm{m}^{3}$; its length is $748 \mathrm{~m}$ and has a width of 215 m. On January 3, 2008, the Greenleaf Basin Rock Avalanche occurred, flowing over the Old Greenleaf Basin Rock Avalanche, covering an area of $100,000 \mathrm{~m}^{2}$ and deposited a volume of about $375,000 \mathrm{~m}^{3}$. Its length is $730 \mathrm{~m}$ with an average depth of $1.22 \mathrm{~m}$. It contributed approximately $0.058 \%$ of the total volume and $0.01 \%$ of the surface area to the active upper lobe portion of the Red Bluff Landslide. The Greenleaf Basin Rock Avalanche was determined to be insignificant in the movement of the active part of the Red Bluff Landslide during the winter of 2007-2008. The original Cascade Landslide Complex map (Wise, 1961) included the Mosley Lakes Landslide which has now been removed because it lacked the characteristics of a landslide like a scarp. The original 
complex $\left(35.5 \mathrm{~km}^{2}\right)$ has been renamed the "Greater Cascade Landslide Complex" (43.0

$\mathrm{km}^{2}$ ), with the addition of the adjacent Stevenson Slide and the elimination of the Mosley Lakes Landslide. 


\section{Acknowledgments}

First and foremost, I want to thank Scott Burns for his patience, his constructive criticism, advice, and most of all, the encouragement provided in my thesis work. This gave me a boost for finishing this work and has meant a lot to me.

A special thanks has to be given to Russ Evarts (USGS, Menlo Park, California) whom I accompanied on a couple of field excursions. The hike from Wanna Point down to Eagle Creek was quite the challenge. Russ was worth a couple of classes in Columbia River Basalts.

Jim O'Connor of USGS Portland provided me with a few pointers regarding interpretation of LiDAR imagery - thank you Jim. Tom Pierson of the Cascade Volcano Observatory in Vancouver, Washington was accommodating in letting me accompany him in setting up pins for GPS monitoring on the Red Bluff Landslide - thank you Tom. I also want to thank Andrew Fountain, committee member, who was especially helpful with final revision suggestions on my thesis.

Thanks to David Scofield of the USACE who let me rifle through the volumes of material the USACE had on the Bonneville Dam Project. I never did receive an invoice for all the copying I did. Thanks again. Special thanks to Isabelle Sarikhan of the Washington Department of Natural Resources who personally provided me with a CD containing the LiDAR DEM of Skamania County. This thesis would have been more difficult otherwise.

Special thanks to my Mother and my sister, who have supported me in all respects and were patient in doing so. 


\section{Table of Contents}

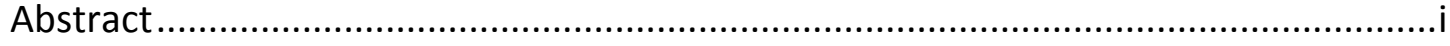

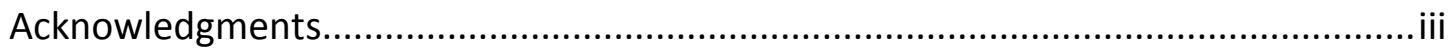

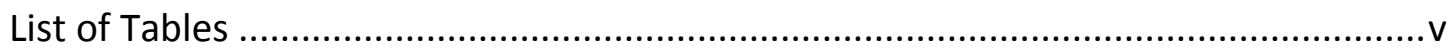

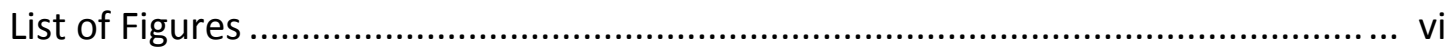

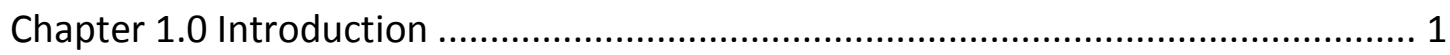

1.1 Hypothesis, Aims and Objectives ....................................................... 5

Chapter 2.0 Background ................................................................................ 7

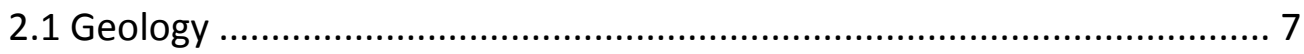

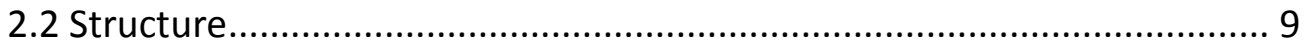

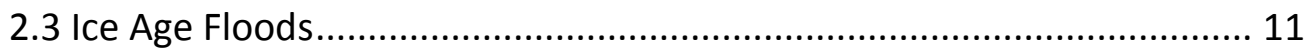

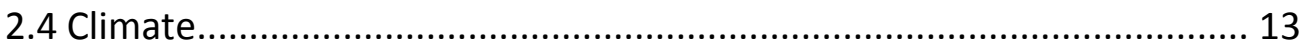

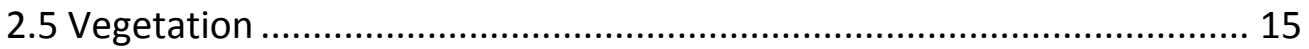

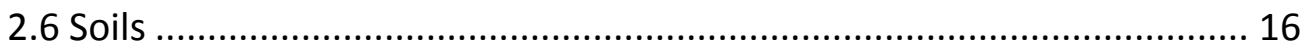

2.7 Cascade Landslide Complex: Earlier Studies ..................................... 17

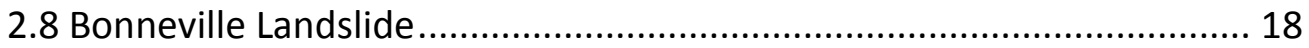

2.9 Red Bluff, Mosley Lakes and Carpenters Landslides .......................... 21

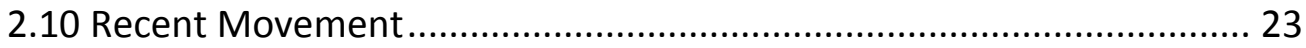

2.11 Greenleaf Basin Rock Avalanche ..................................................... 24

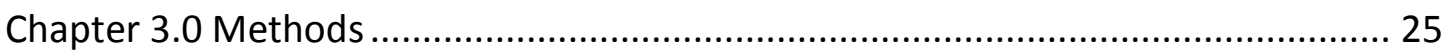

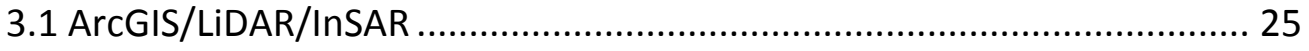

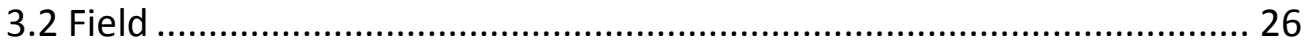

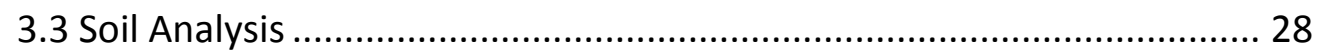

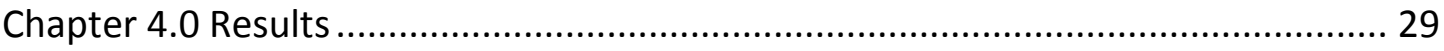

4.1 Active portion of the Red Bluff Landslide .......................................... 29

4.2 Characterization of Major Collapse events on the Red Bluff Landslide.. 33

4.3 Mosley Lakes Landslide: Non-existent ............................................... 34

4.4 Greenleaf Basin Rock Avalanche ....................................................... 38

4.5 Old Greenleaf Basin Rock Avalanche .................................................. 42

4.6 Did Greenleaf Basin Rock Avalanche cause movement to the Red Bluff

Landslide ........................................................................................... 43

4.7 Southwest movement of upper lobe into the Bonneville Landslide ...... 47

4.8 Southeast Movement of the upper lobe from West Headwall .............. 49

4.9 Stevenson Slide ................................................................................ 51

4.10 Reactivation of the Stevenson Landslide at Rock Creek ..................... 55

4.11 Chronologiacal age order of the Cascade Landslide Complex ............. 57

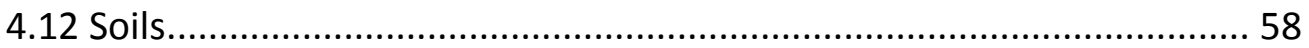

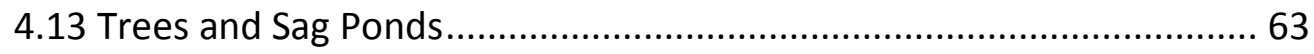

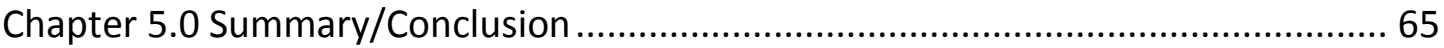

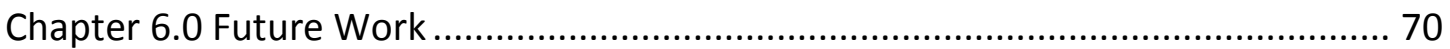

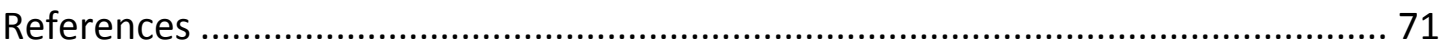




\section{List of Tables}

Table 1. Month of year where precipitation was greater than 48

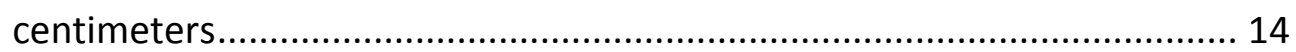

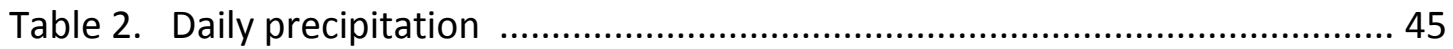

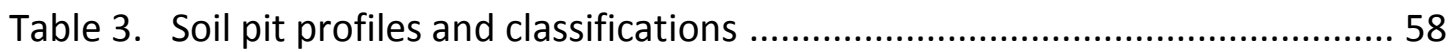

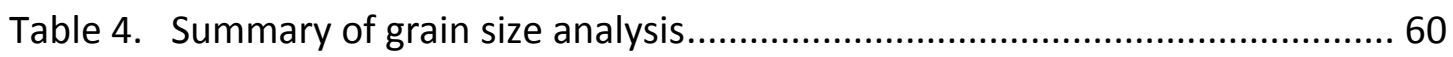

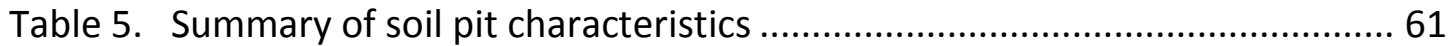

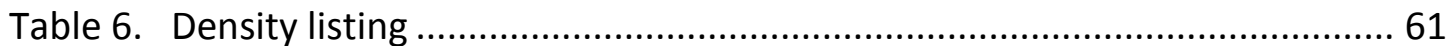




\section{List of Figures}

Figure 1. Columbia River Gorge National Scenic Area .......................................... 1

Figure 2. Cascade Landslide Complex .............................................................. 2

Figure 3. Map of Cascade Landslide Complex, (Wise, 1961)................................. 3

Figure 4. Major complexes in the region (Allen et al., 2009) .................................. 4

Figure 5. Greenleaf Creek Rock Avalanche from Bonneville Dam ........................... 4

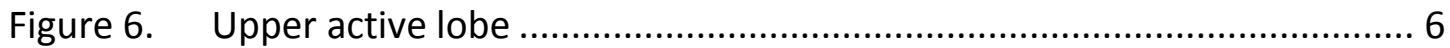

Figure 7. Stratigraphic section of region (USACE, 1994) ........................................ 10

Figure 8. Cross section of Table Mt. to Wanna point (USACE, 1994) ..................... 10

Figure 9. Map of Cascade Landslide Complex, (Wise, 1970)................................ 11

Figure 10. Missoula Flood movement in the Stevenson area................................. 12

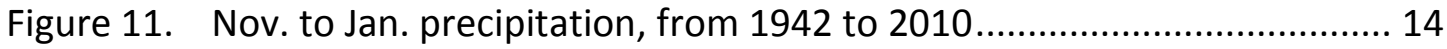

Figure 12. Orthographic of Vegetation for Red Bluff Landslide.............................. 15

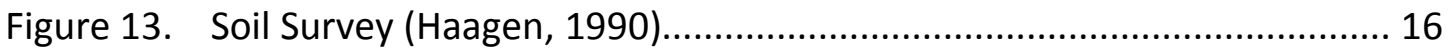

Figure 14. Outwash Islands from breaching of Bridge of the Gods ....................... 19

Figure 15. Detailed cross section of Bonneville Landslide ..................................... 20

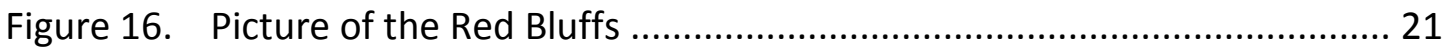

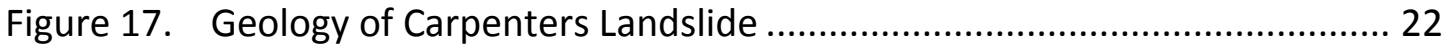

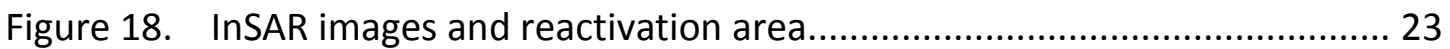

Figure 19. Photo of Greenleaf Basin Rockfall Avalanche ....................................... 24

Figure 20. Shaded relief showing location of soil pits .............................................. 27

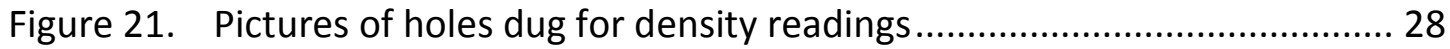

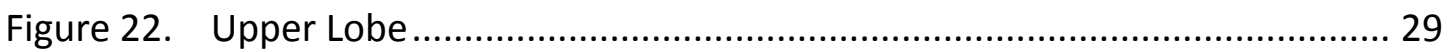

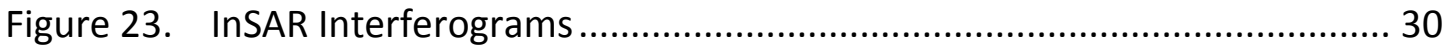

Figure 24. Colorized depiction of blocks on lower section .................................... 30

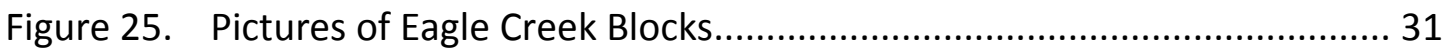

Figure 26. Colorized image of upper Eagle Creek Blocks ........................................ 31

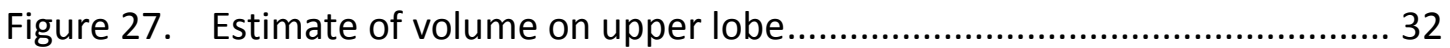

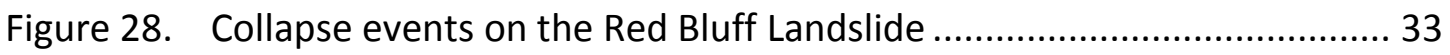

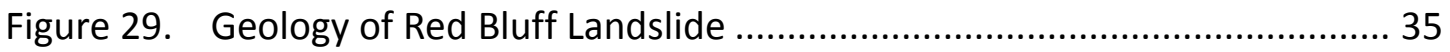

Figure 30. Wise's Mosley Lakes Landslide and X-Section ....................................... 36

Figure 31. Cross section between Stevenson and Red Bluff Slides ........................ 37

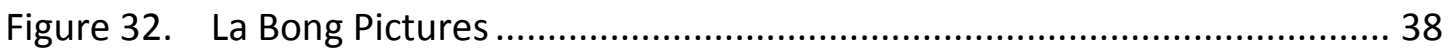

Figure 33. Survey Picture and image of Rockfall.................................................. 39

Figure 34. Pictures of Greenleaf Basin Rock Avalanche....................................... 40

Figure 35. Flow lines of Greenleaf Basin Rock Avalanche..................................... 40

Figure 36. Cross section of Greenleaf Basin Rock Avalanche .............................. 41

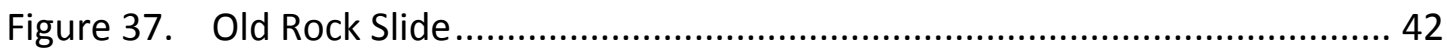

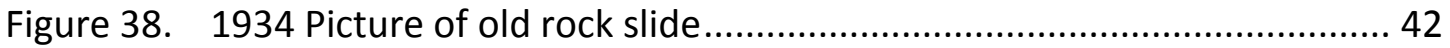

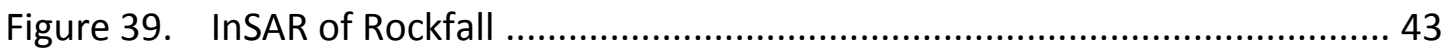

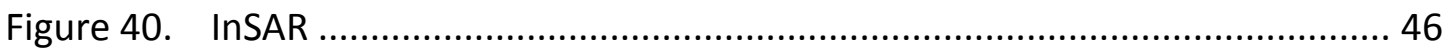

Figure 41. Relief showing overlap onto Bonneville Landslide ............................. 48

Figure 42. Two cross section conceptualization of Missoula Floods ...................... 51 


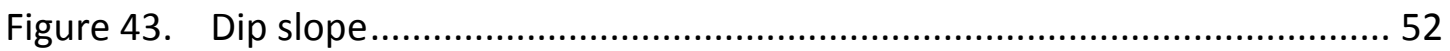

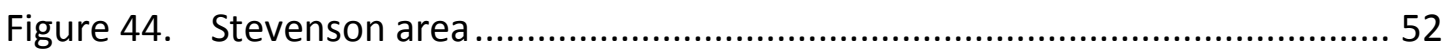

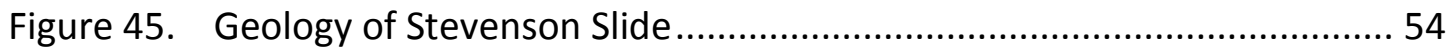

Figure 46. The Greater Cascade Landslide Complex............................................... 55

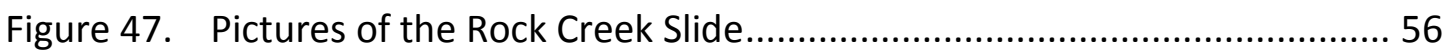

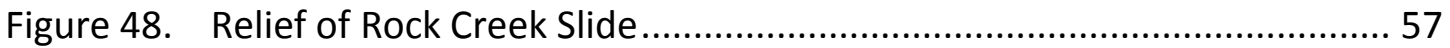

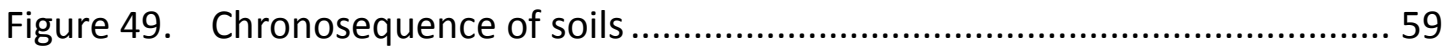

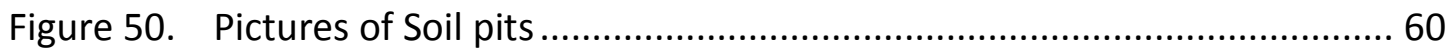

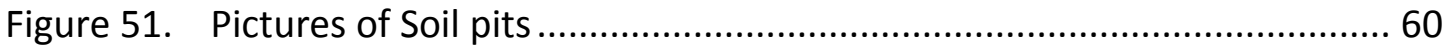

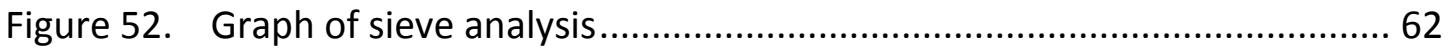

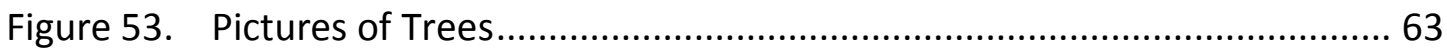

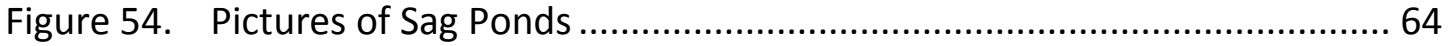

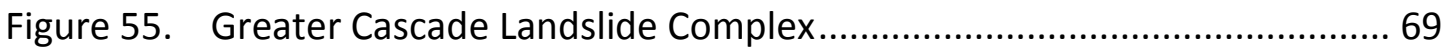




\section{Chapter 1.0 - Introduction}

The Red Bluff Landslide is located approximately 72 kilometers (45 miles) east of Portland, Oregon (Figure 1). It is directly across the Columbia River from the town of

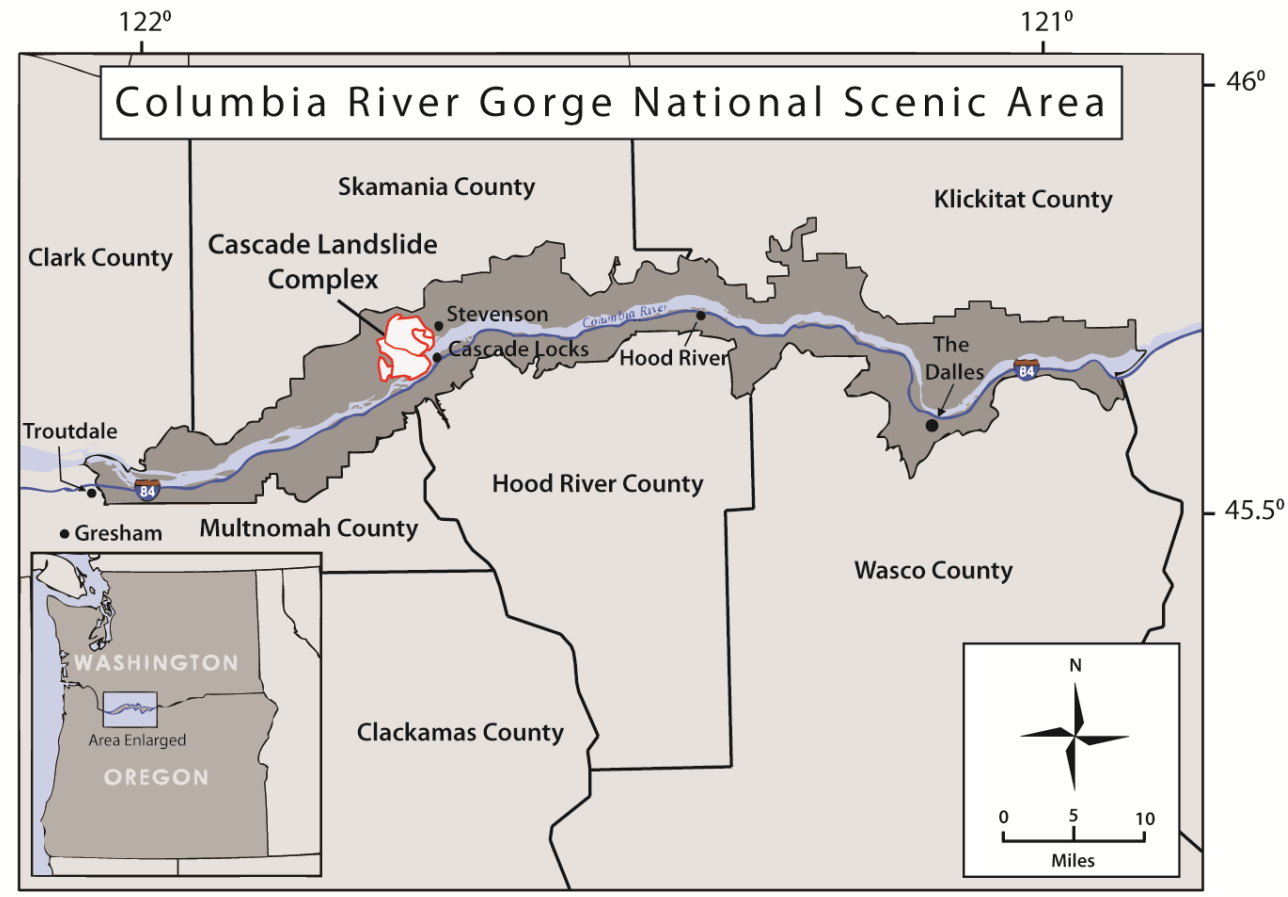

Figure 1. Location of Cascade Landslide Complex in Skamania County.

Cascade Locks, Oregon, in Skamania County, Washington and is part of the Cascade Landslide Complex (Figure 2) (Wise, 1961).

Landslides are abundant on the north side of the Columbia River where "dip slopes" are inclined to the south. Conditions leading to slope failure on the north side include high steep slopes combined with thick heavy sequence of lava flows overlying weak sedimentary rocks, a wet climate, undercutting of inclined bedding by giant glacial floods, tectonic uplift, tilting, seismic activity, rapid drawdowns of Columbia River post glacial floods, hydrothermal alteration of underlying bedrock to clay, debris deposition, 


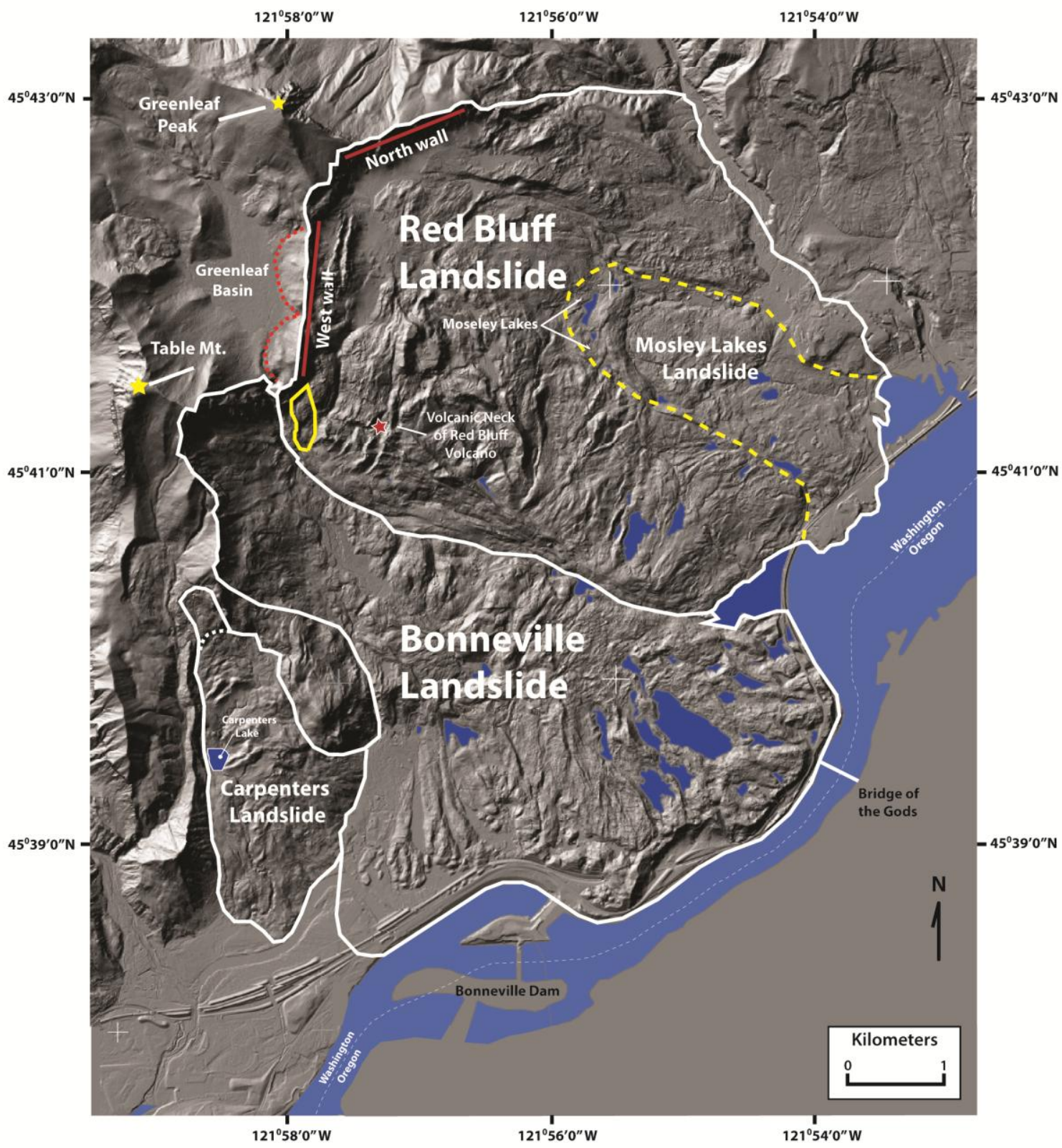

Figure 2. Shaded relief from Lidar topographic data of the $35.5 \mathrm{~km}^{2}$ Cascade Landslide Complex (Carpenters Landslide $=2.74 \mathrm{~km}^{2}$, Red Bluff Landslide $=18.76 \mathrm{~km}^{2}$, Bonneville Landslide $=14.0 \mathrm{~m}^{2}$ ). Yellow dashed line is Wise's Mosley Lakes Landslide ( $3.28 \mathrm{~km}^{2}$ ); yellow solid line is the Greenleaf Creek Rock Avalanche. Red dashed lines are the western flanks of the two collapsed volcanos. Red solid lines are west and north walls of the Red Bluffs. Topographic data from Washington Department of Natural Resources. Modified from Wise (1970).

and reduction of shear strength by weathering (Palmer, 1977). On the south side of the

Columbia River, where dips are away from the Columbia River and to the south, 
landslides are smaller and have different mechanisms. Hydraulic squeezing of clayey layers between formations and debris flows are characteristic in this area. Landslide mechanisms on the Cascade Landslide Complex include gravitational collapse of cliffs causing high velocity rockfalls and plastic flow of impermeable and clayey rocks of the Eagle Creek and Ohanapecosh Formations that underlie the Columbia River Basalts (Palmer, 1977).

The Red Bluff Landslide has been mapped as one of four landslides that make up the $35.5 \mathrm{~km}^{2}$ Cascade Landslide Complex (Wise, 1961) (Figure 2 and 3).

The Bonneville Landslide, Carpenters Landslide and the Mosley Lakes Landslide complete the complex configuration. Along this stretch of the Columbia River, we also find an additional collection of large landslides: the Washougal and the Skamania Landslide Complexes to the west and the Wind Mountain Landslide Complex to the east. On the Oregon side, across

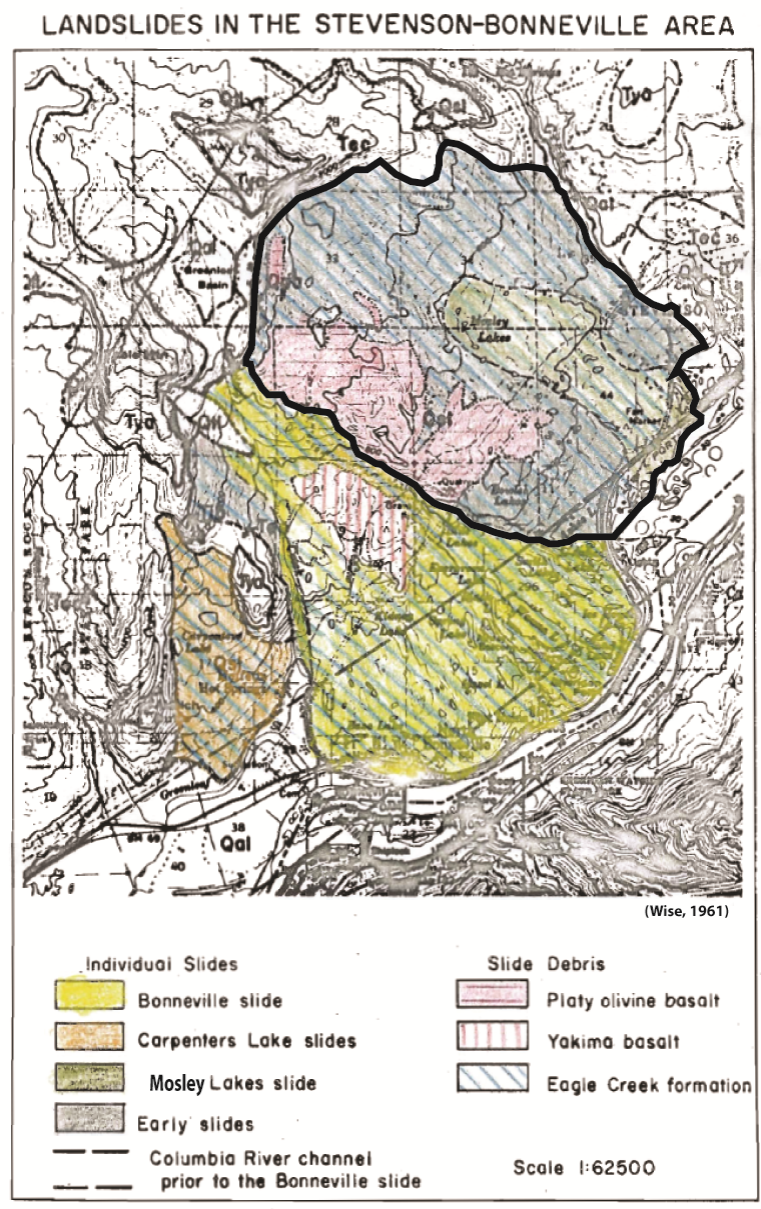

Figure 3. First map of the Cascade Landslide Complex separating the individual slides by Wise (1961). Boundary of Red Bluff Landslide (Black line) superimposed on map.

from the Cascade Landslide Complex, are the Ruckle and Fountain Landslides (Figure 4). 


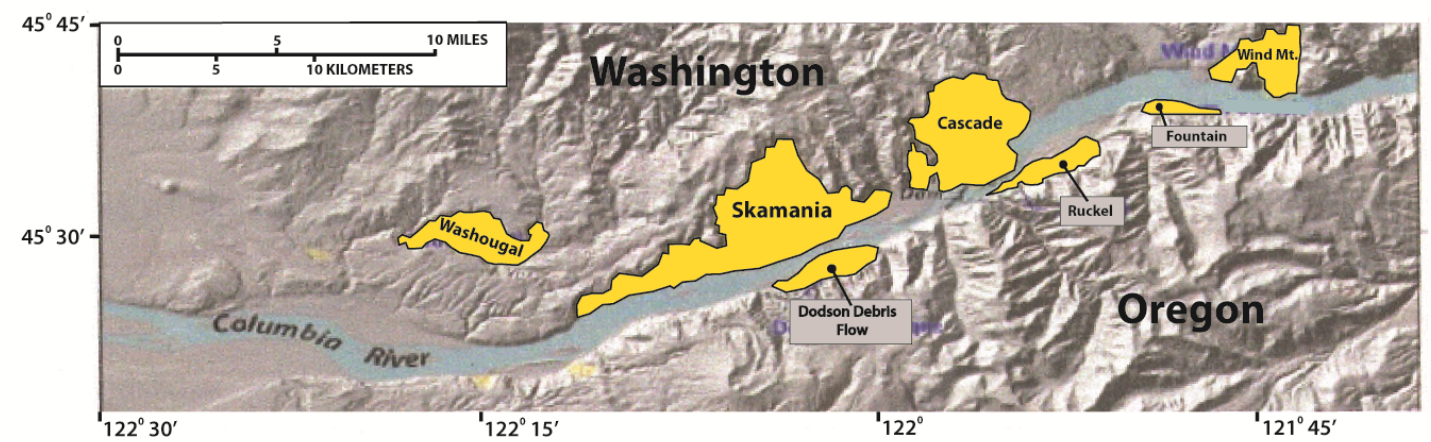

Figure 4. Major Landslides of the region (O'Connor and Burns, 2009).

Little research has occurred on the Red Bluff Landslide since early studies of

Wise (1961), who had been the only geologist to have mapped the Cascade Landslide Complex area (Figure 3). Today, all maps depict the slide as it was mapped originally by Wise (1961). Little is understood about the mechanisms of the Red Bluff Landslide. Recently, attention has focused on to the Red Bluff Landslide because it has reactivated (Pierson and Lu, 2009). The slide is estimated to be moving at a rate estimated in centimeters/year (Tom Pierson, oral communication, 2011). Understanding the movement of the Red Bluff Landslide is important because of its effects on the surrounding infrastructure, the nearby inhabitants and possibly the Bonneville Dam. No documentation of historic movement of the Red Bluff Landslide has been published before (Pierson and Lu, 2009).

In January of 2008, a moderately large rock avalanche landslide occurred on the southern portion of the Red Bluff scarp headwall (Greenleaf Basin Rock Avalanche) (Figure 5). The Greenleaf

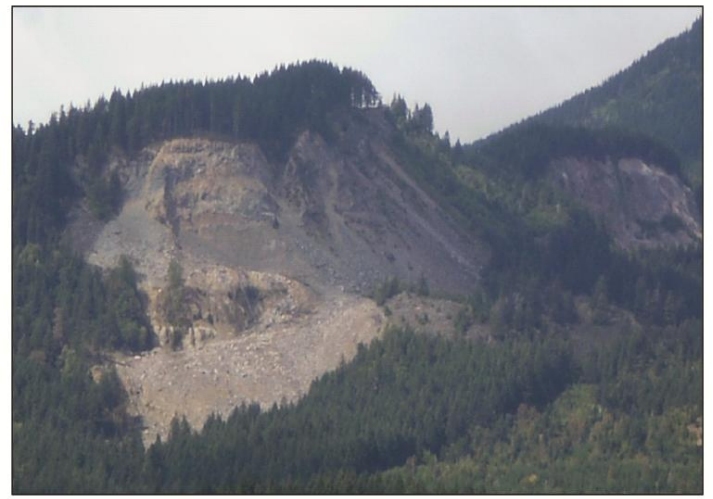

Figure 5. Greenleaf Basin Rock Avalanche. Photograph taken from Bonneville Dam. 
Basin Rock Avalanche was investigated as part of this thesis and studied for its contribution to movement of the Red Bluff Landslide which was first noticed the same winter.

\subsection{Aims, Hypothesis, and Objectives}

The purpose of my thesis is to describe and classify the Red Bluff Landslide. I hypothesize that the Red Bluff Landslide is composed of two parts, an upper lobe that is creeping southward and spreading laterally to the east over a lower semi-fixed portion of the slide (Figure 6). The upper lobe is composed of "recent" debris whereas the lower lobe is composed of ancient debris.

To test my hypothesis, six objectives were identified:

1. Determine whether the Mosley Lakes Landslide is a landslide;

2. Define the spatial extent of the upper lobe;

3. Excavate soil pits to determine an age difference between the upper lobe and the lower area;

4. Describe how the Missoula Floods may have affected the Red Bluff Landslide;

5. Characterize the January 3, 2008 Greenleaf Basin Rock Avalanche and determine if it initiated the re-activation of the Red Bluff Landslide in the winter of 2007-2008; and

6. Develop a chronology, using and analyzing morphological features to characterize the recent evolution of the Cascade Landslide Complex. 


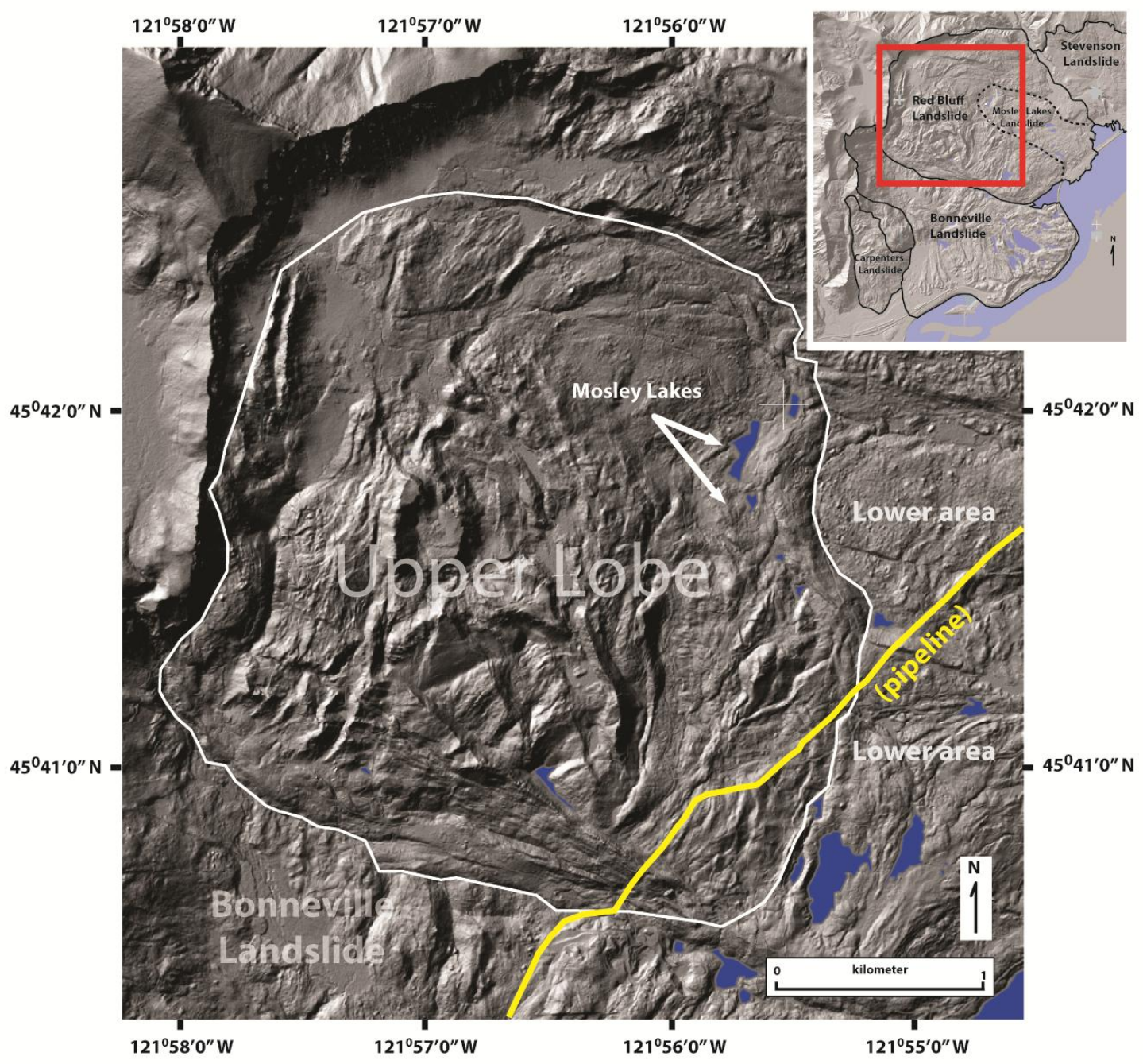

Figure 6. Upper lobe of the Red Bluff Landslide trending to the south overlapping the Bonneville Landslide and spreading laterally to the east over the lower in-place Ohanapecosh/Eagle Creek Formations. White line is boundary of upper lobe. Yellow line is transect of a gas pipeline (NWP) through the area. Inset shows location. 


\section{Chapter 2.0 - Background}

\subsection{Geology}

The Cascade Landslide Complex is located where the Columbia River cuts through the central uplifted core of the Cascade Mountains exposing weaker formations and making this area prone to landsliding. The geology of this part of the Gorge contains four main rock units: Ohanapecosh Formation, Eagle Creek Formation, Columbia River Basalts, and the Quaternary Volcanics.

The oldest is the Ohanapecosh Formation composed of pyroclastic debris deposits from volcanoes of the Western Cascades placed during Eocene time and ending late Oligocene (Wise, 1970). The main feature of this formation is the zeolitic and argillic alteration, where primary joints and cavities have been sealed and altered hydrothermally, making it nearly totally impermeable to ground water. The thickness of the Ohanapecosh Formation is well over 3,000 meters $(10,000$ feet), all mostly andesitic and dacitic in composition (Wise, 1970). At the top of the Ohanapecosh, the formation has been weathered and converted to a purplish-brown, clay saprolite, which is considered to be the failure plane of all the major landslides in this area (Waters, 1973: Palmer, 1977).

An erosional unconformity separates the Ohanapecosh Formation from the overlying Eagle Creek Formation. The Eagle Creek Formation is a sequence of weakly lithified, light-brown to light-gray, predominantly coarse-grained volcaniclastic rocks and local interbedded lava flows (Wise, 1961, 1970; Waters, 1973), deposited from mud flows and slurry floods washed from nearby active volcanoes. It is interpreted as being 
a debris fan extending south and southeast from one or more andesitic volcanoes (Wise, 1970). The upper most 244 meters (800 feet) of the Eagle Creek Formation is exposed in the Red Bluffs (Wise 1970). Plagioclase from a dacitic lithic pyroclastic-flow deposit yields a ${ }^{40} \mathrm{Ar} /{ }^{39} \mathrm{Ar}$ age of about $19 \mathrm{Ma}$ (Evarts, 2011 personal communication). The top of the Eagle Creek Formation is marked by an erosional unconformity (Waters, 1973) and is the surface upon which the Grande Ronde Basalts flowed during the early to middle Miocene time (Wise, 1970).

Punching through the Ohanapecosh Formation, the Eagle Creek Formation and the Columbia River Basalts are Quaternary volcanics producing lava flows from various vents in the area. The Quaternary volcanic rocks found on the Red Bluff Landslide are andesitic basalts sourced from the "Red Bluffs volcano" (Wise, 1961) that erupted within the valley of upper Greenleaf Creek, damming the stream with lava and forming Greenleaf Basin (Wise, 1970; Korosec, 1987). The Red Bluffs Volcano is dated 146,000 years B.P. (Russ Evarts, U.S.G.S., personal communication, 2010). Not too far from the head of the Red Bluff Landslide, a well preserved intact cinder cone and undisturbed flows demonstrate large block sliding. A second volcano (Russ Evarts, U.S.G.S., personal communication, 2011) is located adjacent and to the north. Both volcanoes ("Red Bluff Volcanoes") are now collapsed remnants which cover an area of $4.1 \mathrm{~km}^{2}$ on the Red Bluff Landslide.

The Weigle Formation is a name used by the Army Corps of Engineers. This unit (Weigle) was first recognized by Holdredge (1937) while investigating the foundation area of the Bonneville Dam. Its description was intermediary between the classical Eagle 
Creek and the Ohanapecosh Formations in degree of alteration, induration and grain size. It remained un-named until Wise (1961) termed it the Weigle Formation while working on his PhD dissertation over in the Wind River area. It was adopted by the Army Corp of Engineers (USACE, 1994) while building the second power house for the Bonneville Dam. While continuing work in the Wind River area, Wise (1970) had decided to drop the name Weigle and put it at the top of the Ohanapecosh Formation. Wise's (1970) report came out after the commencement of the initial investigations for the new powerhouse in which the Weigle was initially used by the USACE. The Weigle designation is being retained by the USACE to maintain consistency with the investigation work. The new power house foundation rock is considered by Wise to be the Ohanapecosh Formation (USACE, 1994) (Figures 7 and 8). Wise (1970) includes the Weigle in the Ohanapecosh Formation.

\subsection{Structure}

The study area is represented by gentle folds, low structural relief, and an average dip of $7^{0}$ to the south (Pierson and Lu, 2009). Because the Cascade Landslide Complex is covered by landslide debris and thick vegetation, identifiable fractures and faults are difficult to detect. Recent investigations by Evarts (personal communication, 2011) finds evidence that the stratigraphy on both sides of the Columbia River matches up indicating no apparent vertical offset in any of the stratigraphic units. If there are faults through the area, displacement would have to be lateral. 
A.

USACE (1994)

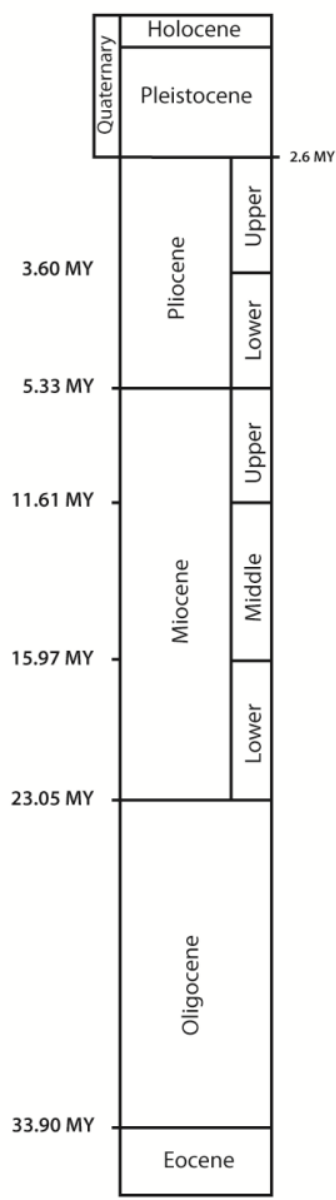

\begin{tabular}{|c|}
\hline $\begin{array}{c}\text { High Cascade } \\
\text { Volcanics } \\
\text { (Qtv) }\end{array}$ \\
\\
\\
\\
\hline $\begin{array}{c}\text { Troutdale Formation } \\
\text { (Tt) } \\
\text { Rhododendron } \\
\text { Formation } \\
\text { (Tr) } \\
\text { Columbia River } \\
\text { Basalts } \\
\text { (Tcr) }\end{array}$ \\
\hline $\begin{array}{c}\text { Eagle Creek } \\
\text { Formation } \\
\text { (Tec) }\end{array}$ \\
\hline Weigle Formation \\
(Tw)
\end{tabular}

B.

Wise (1970)

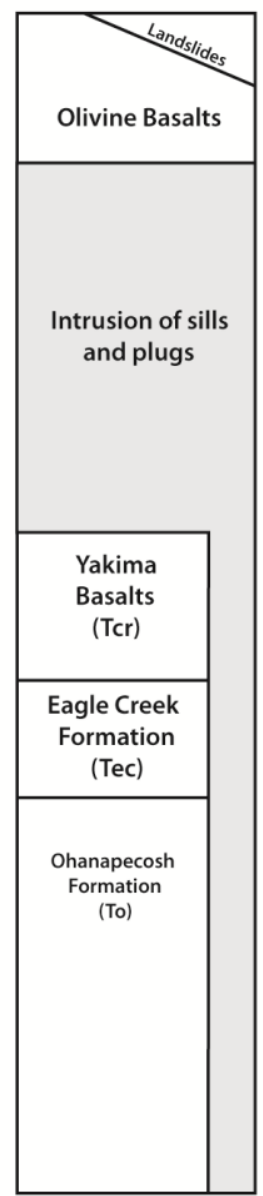

Figure 7. Stratigraphic section of Cascade Landslide Complex area. Shown are a. USACE (1994), b. Wise's Ohanapecosh (1970).

Table Mtn.

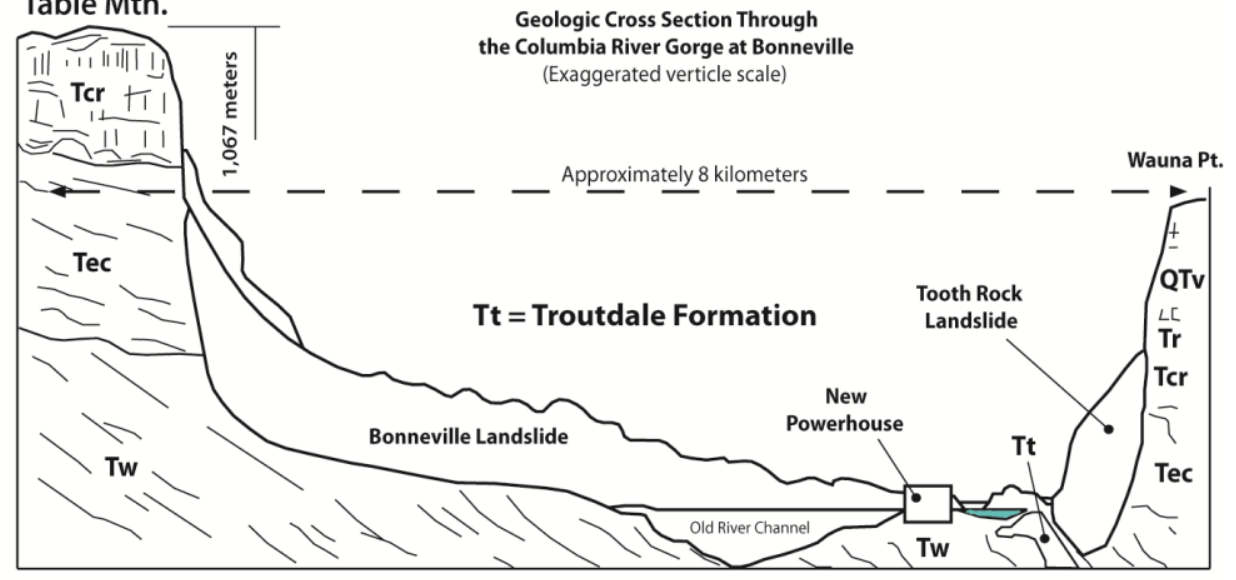

Figure 8. Cross section by the USACE (1994). 
Wise (1971) indicates dips that

are to the southwest along the Wind

River and Nelson Creek. Outside the Red

Bluff Landslide area, to the northeast

along Rock Creek, the dips are to the

south (Figure 9). These readings are

generally consistent with the tension

cracks evident on the north part of the

Red Bluff Landslide. In the southwest

part of the Cascade Landslide Complex,

along and close to Hamilton Creek, dips

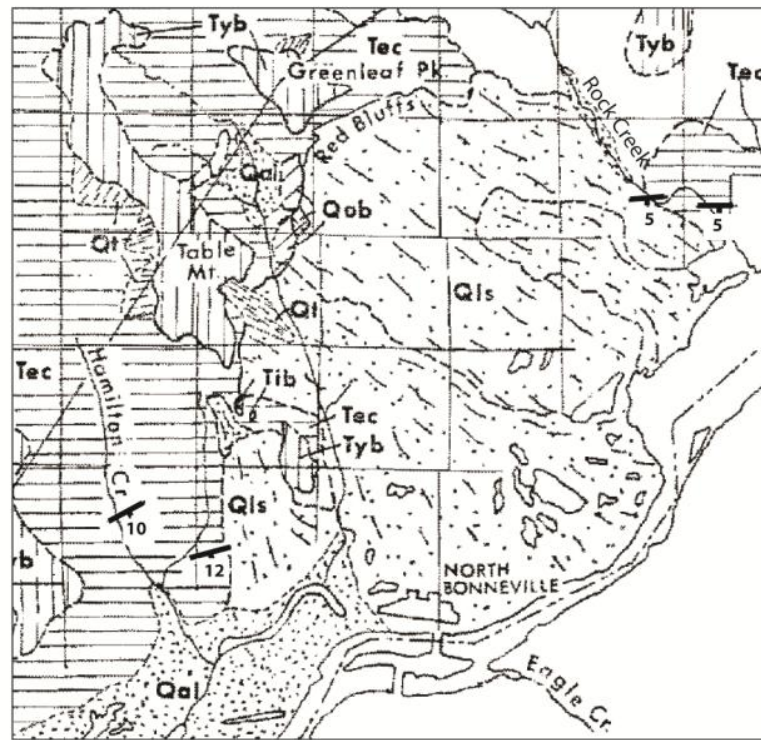

Figure 9. Partial map of Wind River Area by Wise (1970) showing geology of the Cascade Landslide complex. Yakima Basalts (Tyb), olivine basalts (Qob), Eagle Creek Formation ( $\mathrm{Tec}$ ), gabro, diabase, microgabbro (Tib), landslide debris derived from CRB and Eagle Creek Formation (QIs), CRB talus cones (Qt), alluvium (Qal). Parts modified for clarity.

are to the SSE. These dip readings imply that the whole of the Cascade Landslide Complex has a very shallow bowl shape and is consistent with the strike of the beds that are almost parallel to the northwest trending Rock Creek and then bending around Greenleaf Peak and Table Mountain (Russ Evarts, U.S.G.S., personal communication, 2011). The orientation of stratigraphic units indicates a SE-plunging syncline with an axis in the vicinity of Table Mountain (Bela, 1970; Evarts, personal communication, 2011).

\subsection{Ice Age Floods}

Toward the end of the Pleistocene, the Cordilleran Ice Sheet advanced southward into Washington, Idaho, and Montana during Late Wisconsin time. One of its eastern most terminal lobes, the Purcell Trench Lobe, blocked the Clark Fork River impounding and creating Glacial Lake Missoula. For a period of 3,000 plus years ending 
15,000 years ago, up to 89 glacial outbursts occurred (Atwater, 1984), pouring massive amounts of water through Idaho and into eastern Washington, through the Pasco Basin and down through the Columbia River Gorge. Forty of these floods probably reached the study area (Waitt, 1980). Benito and O'Connor (2003) calculated that the largest flood reached levels of $305 \mathrm{~m}$ asl $(1,000 \mathrm{ft})$ in the Hood River area and $122 \mathrm{~m}$ asl $(400 \mathrm{ft})$ at Crown Point. Based on these figures, flood level is interpolated to have reached $267 \mathrm{~m}$ asl (875 ft) at Dog Mountain, and inferred to $253 \mathrm{~m}$ asl ( $830 \mathrm{ft}$ ) on the Cascade Landslide Complex (Allen et al., 2009;Benito and O'Connor, 2003). Figure 10 shows a conceptualized path the largest of Missoula Floods moved in this region.

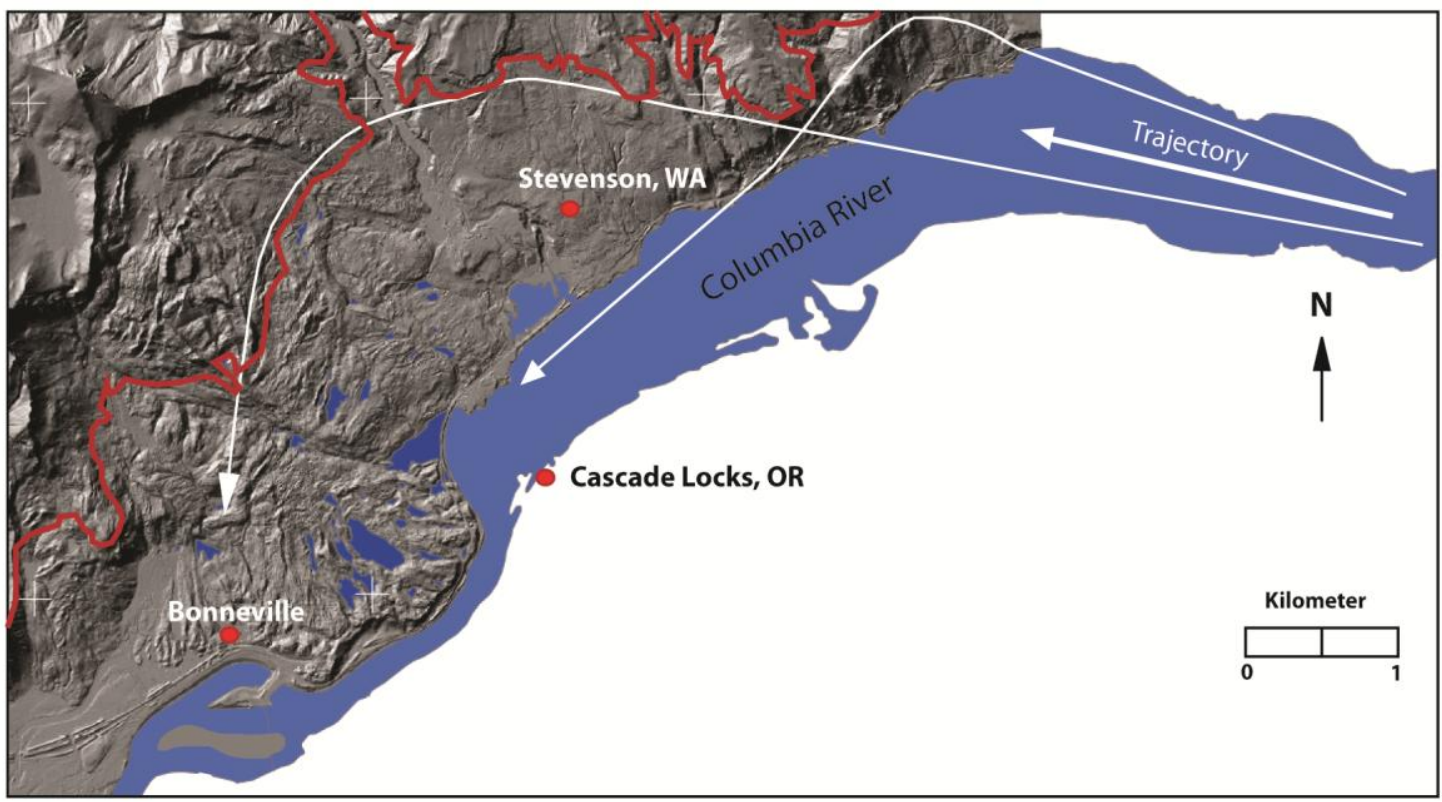

Figure 10. Conceptualized routing of Missoula Flood waters through the Cascade Landslide Complex area. Red Solid line is the $830^{\prime}$ ( 253 meters) contour.

Pre-Wisconsinan floods may have also occurred in this area based on a few exposed deposits in the form of paleosols containing calcium carbonate or caliches that 
formed $\mathrm{Bk}$ and $\mathrm{K}$ soil horizons in the Pasco Basin having reversed magnetic polarity and being older than 700,000 years (Bjornstad and Fecht, 1989; Medley, 2012). Although these are suspected to have contributed to the physical expression of the Gorge, little evidence of them remain in the Gorge.

\subsection{Climate}

Climate data are of major importance to landslide investigations, as increased water in the soil/rock system is the primary contributing factor to most landslides (Burns, 1998). Precipitation intensity and duration are also crucial in triggering movement of a slide mass (Cornforth, 2005). Slope failures are often the result of a single storm event occurring when soil is already saturated (Burns, 1998: Cornforth, 2005). Movement is generally accelerated during periods of high rainfall over several weeks.

The climate in the Cascade Landslide Complex area is greatly influenced by the Cascade and Coastal mountain ranges. The Cascade Landslide Complex is protected from severe winter storms moving inland from the ocean by the Coast Range, and the Cascade Range protects the area from the high summer and low winter temperatures of eastern Oregon and Washington (Haagen, 1990). In winter, the average temperature at Bonneville is $3.9^{\circ} \mathrm{C}\left(39^{\circ} \mathrm{F}\right.$.). The average winter daily minimum temperature at Bonneville is $0.6^{\circ} \mathrm{C} .\left(33^{\circ} \mathrm{F}.\right)$ In the summer, the average temperature is $18.3^{\circ} \mathrm{C} .\left(65^{\circ} \mathrm{F}.\right)$ The average summer daily maximum temperature is about $24.4^{\circ} \mathrm{C} .\left(76^{\circ} \mathrm{F}\right.$ ) (Haagen, 1990). Average seasonal snowfall is $33 \mathrm{~cm}$. (13 in.) at Bonneville. Average annual precipitation, observed at Bonneville Dam (Station \# 350897; (1947 - 2010) is $191.5 \mathrm{~cm}$. 
(75.39 in.) (WRCC, 2010). Months with the heaviest precipitation are from the beginning of November through January (Figure 12). The maximum annual precipitation amount

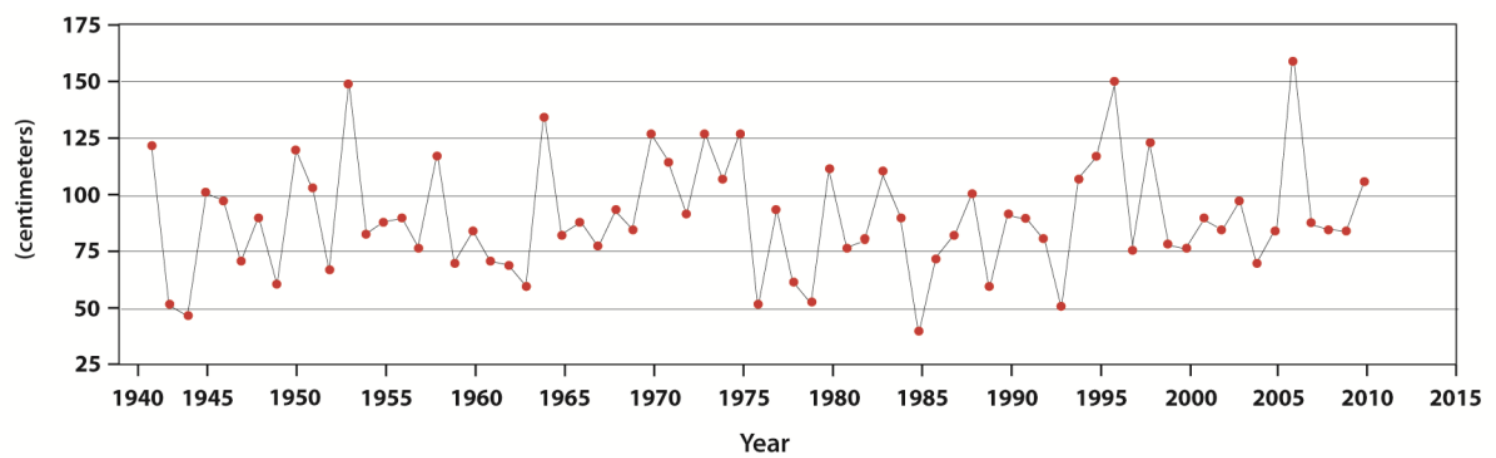

Figure 11. Precipitation from 1942 to 2011 for the months of November, December and January (WRCC, 2010)

recorded was $301.3 \mathrm{~cm}$. (118.6 in.) in 1996 and a minimum annual amount recorded was $120.1 \mathrm{~cm}$. (47.3 in.) in 1944 (WRCC, 2010). Months (1942 to 2007) with the most intense rainfall (over $48.3 \mathrm{~cm}$.) are shown in Table 1.

Table 1. Month of the year where precipitation was greater than 48.26 centimeters (19.00 inches) (WRCC, 2010).

\begin{tabular}{|c|c|c|c|c|c|c|c|}
\hline Year & Month & Centimeters & Inches & Year & Month & Centimeters & Inches \\
\hline 1942 & November & 67.51 & 26.58 & 1977 & December & 50.09 & 19.72 \\
\hline 1942 & December & 42.23 & 19.38 & 1980 & December & 51.41 & 20.24 \\
\hline 1948 & December & 49.56 & 19.51 & 1981 & December & 49.66 & 19.55 \\
\hline 1949 & February & 51.61 & 20.32 & 1988 & November & 50.49 & 19.88 \\
\hline 1953 & January & 78.08 & 30.74 & 1995 & November & 55.80 & 21.97 \\
\hline 1960 & November & 50.19 & 19.76 & 1996 & December & 70.97 & 27.94 \\
\hline 1961 & February & 55.17 & 21.72 & 1998 & November & 49.86 & 19.63 \\
\hline 1964 & December & 59.74 & 23.52 & 1999 & November & 48.74 & 19.19 \\
\hline 1970 & January & 54.99 & 21.65 & 2006 & January & 49.17 & 19.36 \\
\hline 1973 & November & 52.81 & 20.79 & 2006 & November & 73.56 & 28.96 \\
\hline 1973 & December & 56.36 & 22.19 & 2007 & December & 49.40 & 19.45 \\
\hline 1975 & January & 53.59 & 21.10 & & & & \\
\hline
\end{tabular}




\subsection{Vegetation}

Vegetation cover is shown in Figure 12. The native vegetation for the Red Bluff Landslide is mainly mixed conifers and shrubs. Douglas fir, western hemlock, and red alder are the main woodland species. Other species growing in the area are grand fir,

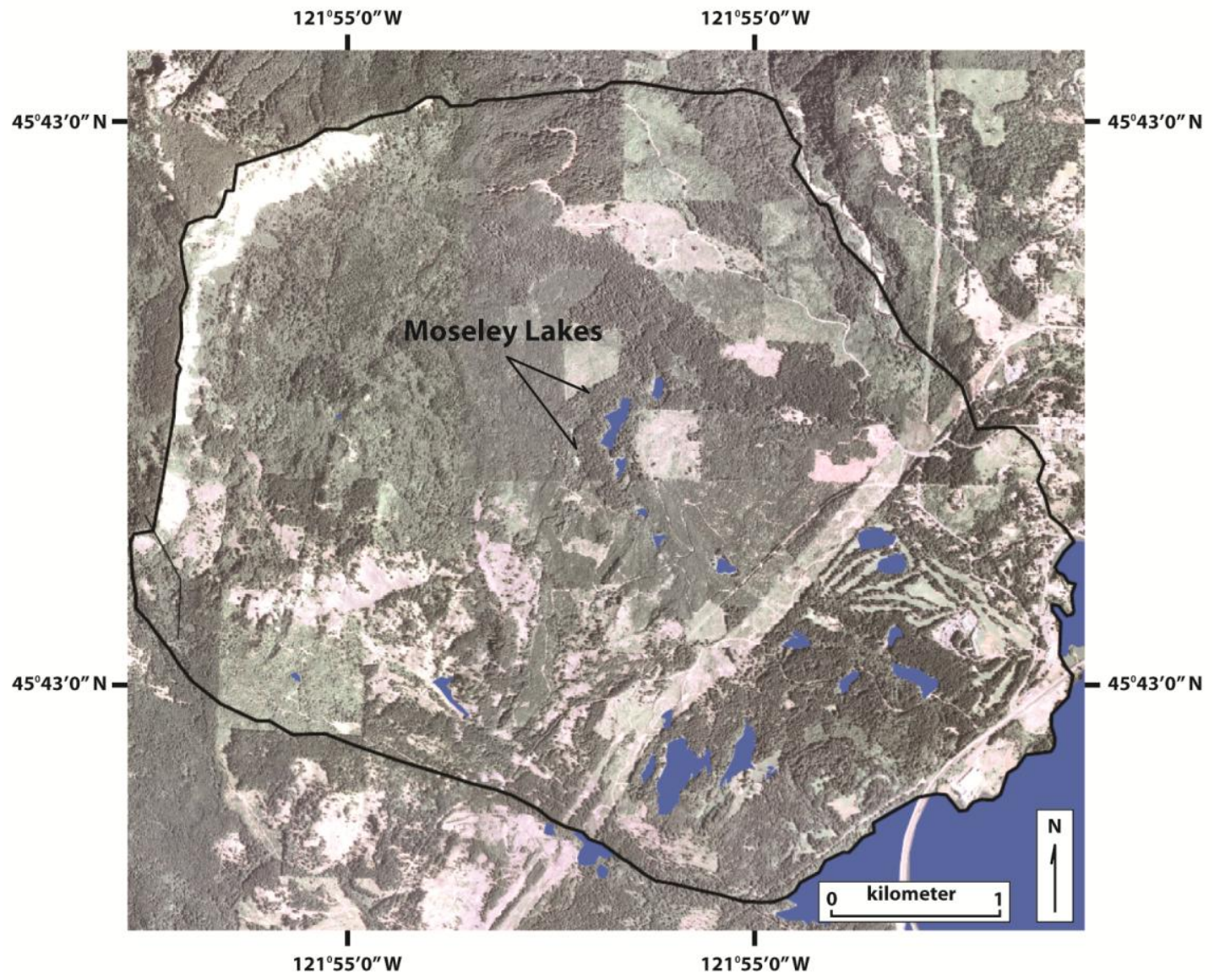

Figure 12. Othographic view of the Red Bluff Landslide. Note the forest areas that have been harvested.

big leaf maple, vine maple, Oregon grape, red huckleberry, trailing blackberry, creambush oceanspray, western hazel, Pacific dogwood, common snowberry, thimbleberry, and dwarf rose (Haagen, 1990). Not included in the Soil Survey of 
Skamania County and observed in the field are western red cedars, which are common on the Red Bluff Landslide, especially in the upper elevations.

\subsection{Soils}

The specific soil types for the study area, shown in Figure 13, are Steever Stony Clay Loam, Steever-Rock outcrop complex, Stevenson loam, Typic Dystrandepts and

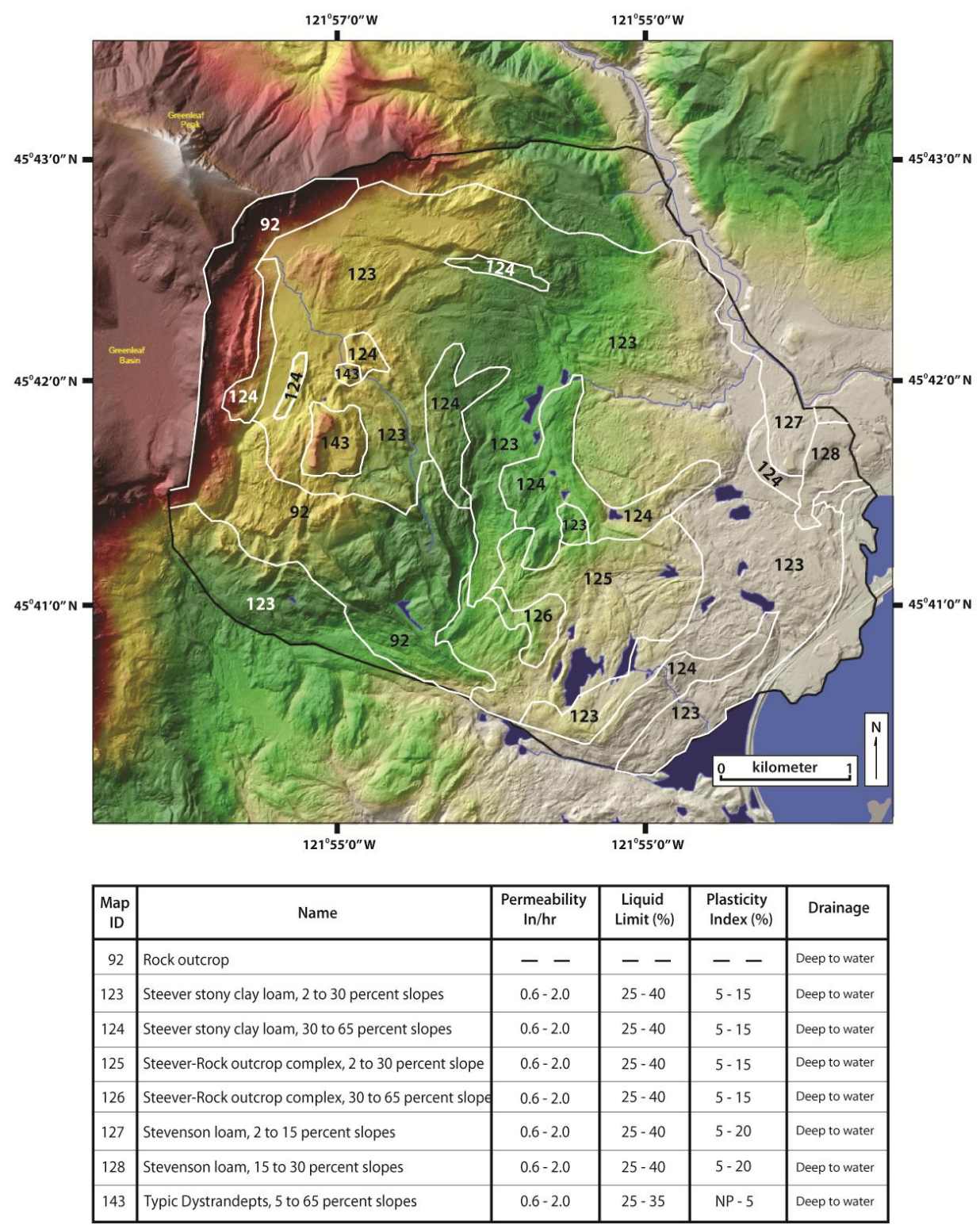

Steever series - Loamy-skeletal, mixed, superactive, mesic Typic Humudepts.

Figure 13. Red Bluff Landslide Soil Survey (based on Haagen, 1990) 
Rock outcrop-Rubble land complex (Haagen, 1990). The Steever Stoney Clay Loam makes up around $70 \%$ of the Red Bluff Landslide area. The Steever Series (Typic Humudepts) consists of very deep, well drained soils on back slopes, foot slopes, and toe slopes and formed in colluvial landslide material derived from conglomerate, andesite, and basalt parent material (Haagen, 1990). The remaining $30 \%$ of the soil types found on the Red Bluff Landslide are the Stevenson loam, Rock outcrops, and Typic Dysandrepts. The Stevenson loam (Typic Humudepts) is found on the lower portions of the Red Bluff Landslide in low sloping areas. The Typic Dysandrepts are very deep, well drained soils on cinder cones. They are formed in volcanic material derived from volcanic ash, cinders and pumice. The Rock outcrop-Rubble land complex is found on mountain slopes and is barren. This unit is about 60 percent rock outcrop and 30 percent rubble land and consists of about 90 percent fragmented rock, including cobbles, stones, and boulders of andesite and basalt.

\subsection{The Cascade Landslide Complex: Earlier Studies}

The earliest accounts of the Cascade Landslide Complex came from the Native Americans who passed down oral information over several generations. Lawrence (1937) and Lawrence and Lawrence (1958) summarized these oral histories indicating Native Americans "could cross the river without getting their feet wet" and that "the falls are not ancient, and that their fathers voyaged without obstruction in their canoes as far as The Dalles. It was also noted that "the river was dammed up at this place, which caused the waters to rise to a great height far above and that after cutting a passage through the impeding mass down to its present bed, these rapids made their 
appearance". The damming of the Columbia River by the landslide deposit has been recorded in Indian legends and referred to as "The Bridge of the Gods" (Palmer, 1977).

The earliest written accounts came from Lewis and Clark in 1805 (Moulton, 1991). They were the first to describe a submerged forest between the Cascade Rapids and The Dalles that was drowned by a lake that formed behind the dam. Judging from the fresh appearance of drowned snags, Lewis and Clark first speculated that the blockage formed just a couple of decades prior to their journey (Moulton, 1991). Today, the Cascades Rapids, as well as the drowned forest, are completely submerged beneath the even higher water level created by Bonneville Dam.

Lawrence (1937) mapped the drowned forest during low water in 1934 and 1935. He catalogued over 1800 trees in the twenty five miles above Cascade Rapids. Using dendrochronology, he concluded that the submerged trees must have been drowned prior to 1562 AD. In 1958, two decades after the closure of Bonneville Dam, Lawrence submitted two retained samples of the submerged forest to radiocarbon dating giving an age estimate of about seven hundred years ago. This lead Lawrence to conclude that the landslide had occurred in about AD 1250.

\subsection{Bonneville Landslide}

The $14 \mathrm{~km}^{2}$ Bonneville Landslide is the youngest landslide in the complex (Wise, 1961). It failed rapidly surging downslope, spreading debris over, across, and damming the Columbia River. The rapid failure initiated liquefaction of river sediments over which the toe of the slide was able to move rapidly onto the opposite valley wall (Palmer, 1977). 
The landslide is considered to have occurred between 1425 and 1450 AD

(O'Connor and Burns, 2009). The slide created a temporary dam and a lake (Lake of the Gods) that rose to a maximum impoundment of 90m asl. (O'Connor, 2011), extending approximately $142 \mathrm{~km}$ (88 miles) upriver (O'Connor and Burns, 2009). All indications point to an impoundment that was maintained for several years ( $\mathrm{O}^{\prime}$ Connor and Burns, 2009). Breaching of the debris dam occurred near the south side of the gorge where the present channel is located. The landslide diverted the river channel towards the Oregon shoreline (Wang et al., 2002; Palmer, 1977). The magnitude of the flood, caused by the breaching of the dam, is evident by the numerous islands and terraces present
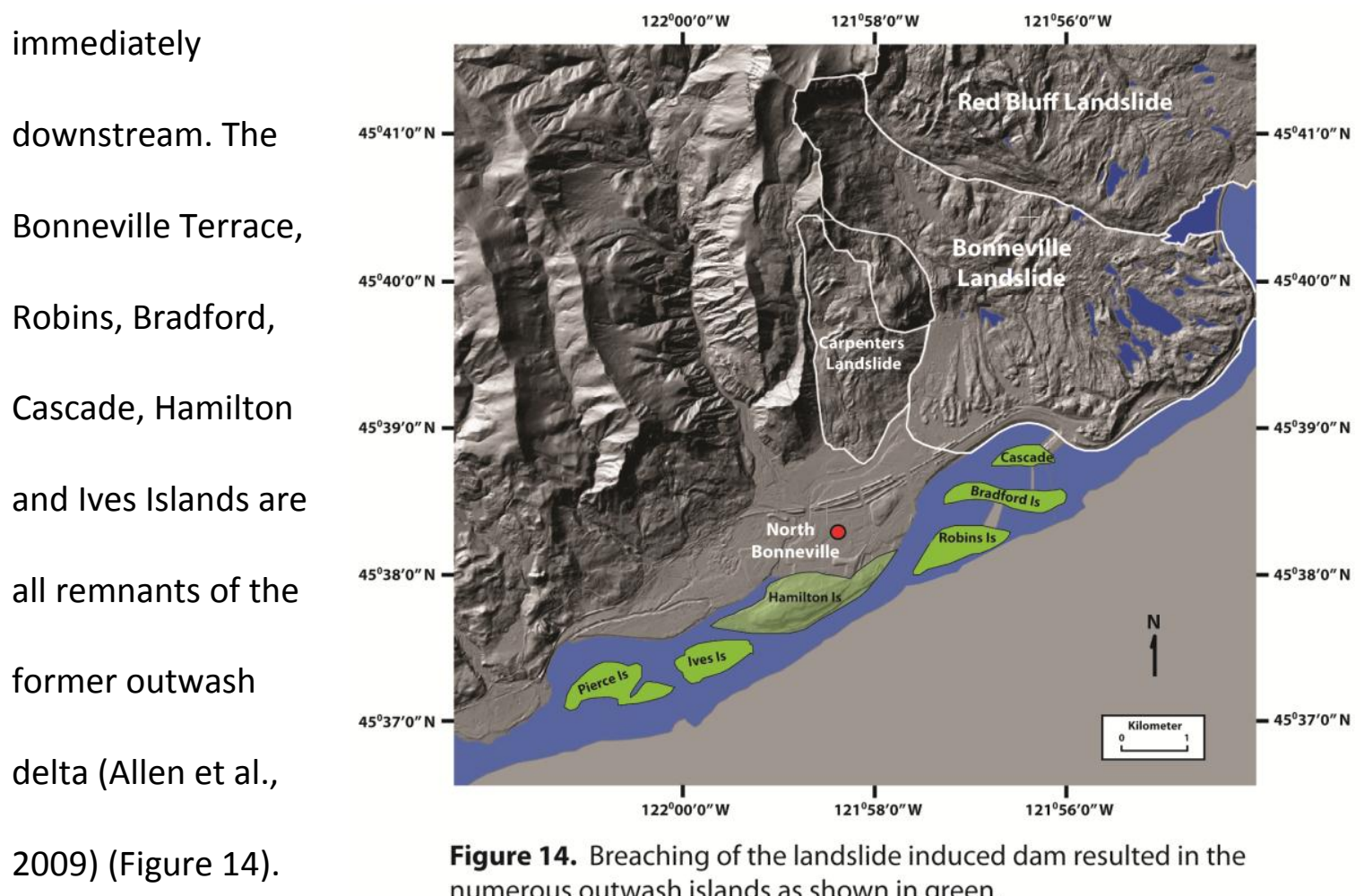

Figure 14. Breaching of the landslide induced dam resulted in the numerous outwash islands as shown in green.

The most detailed study to date resulted in a cross section by the Corps of Engineers

(Figure 15). 

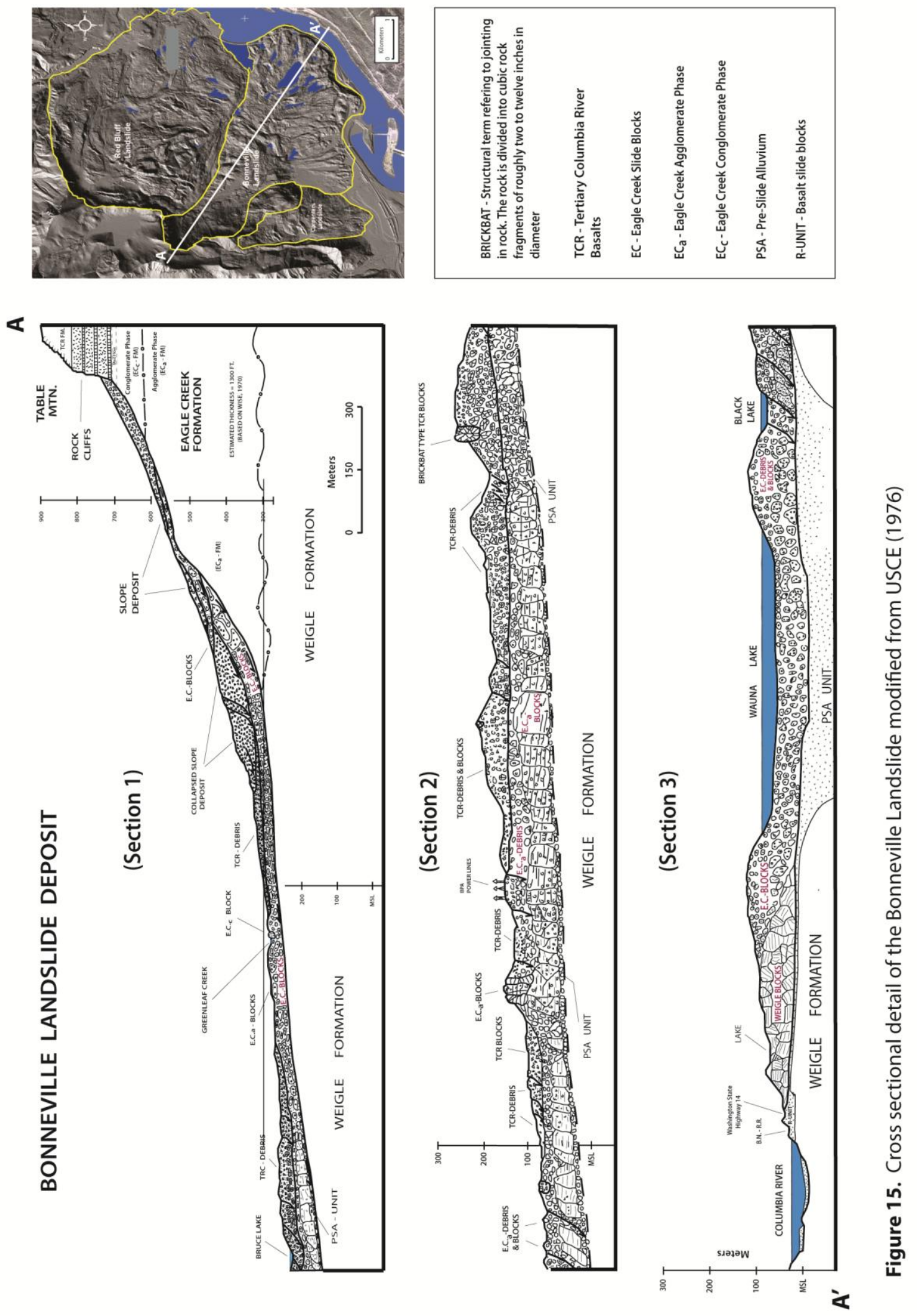


\subsection{Red Bluff Landslide, Mosley Lakes Landslide and the Carpenters Landslide}

The Red Bluff Landslide (RBL), adjacent to the Bonneville Landslide covers an area of $18.76 \mathrm{~km}^{2}$ and is the eastern most portion of the Cascade Landslide Complex (Figure 2). Its most striking feature is the scarp headwall, known as the Red Bluffs (Figure 16). The only description of the Mosley Lakes Landslide by Wise (1961) is that it

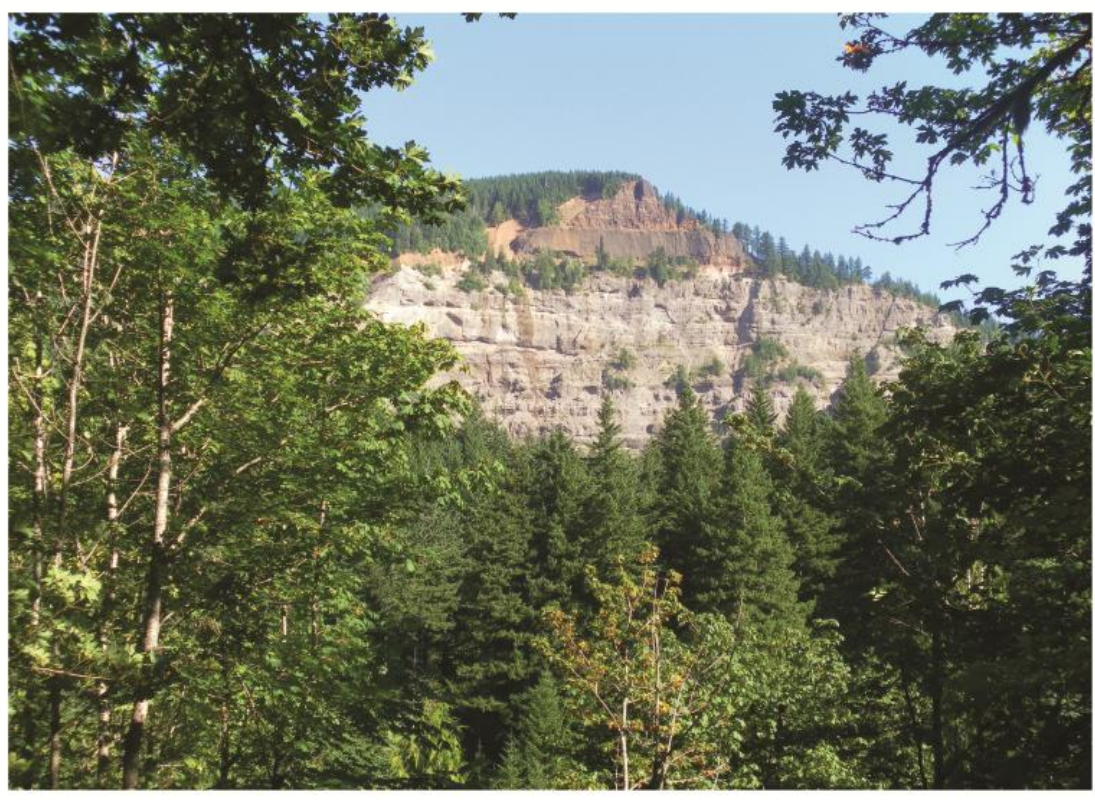

Figure 16. Photograph of the Red Bluffs from the Red Bluff Landslide.

originated near the Mosley Lakes, covers an area of one square mile (Wise, 1961), probably moved a few hundred feet into the Columbia River, and had transport distances on the order of hundreds of feet.

The Carpenters Landslide, adjacent to and west of the Bonneville Landslide covers an area of $2.75 \mathrm{~km}^{2}$ (Figure 17). Wise (1961) briefly describes the Carpenters Landslide to have moved during a two to three week period, and Palmer (1977) states that reports of rockfalls close to Carpenters Lake occurred in 1955 and 1974. Other than this, detailed information is lacking. It is likely to have occurred before the Bonneville Landslide. 

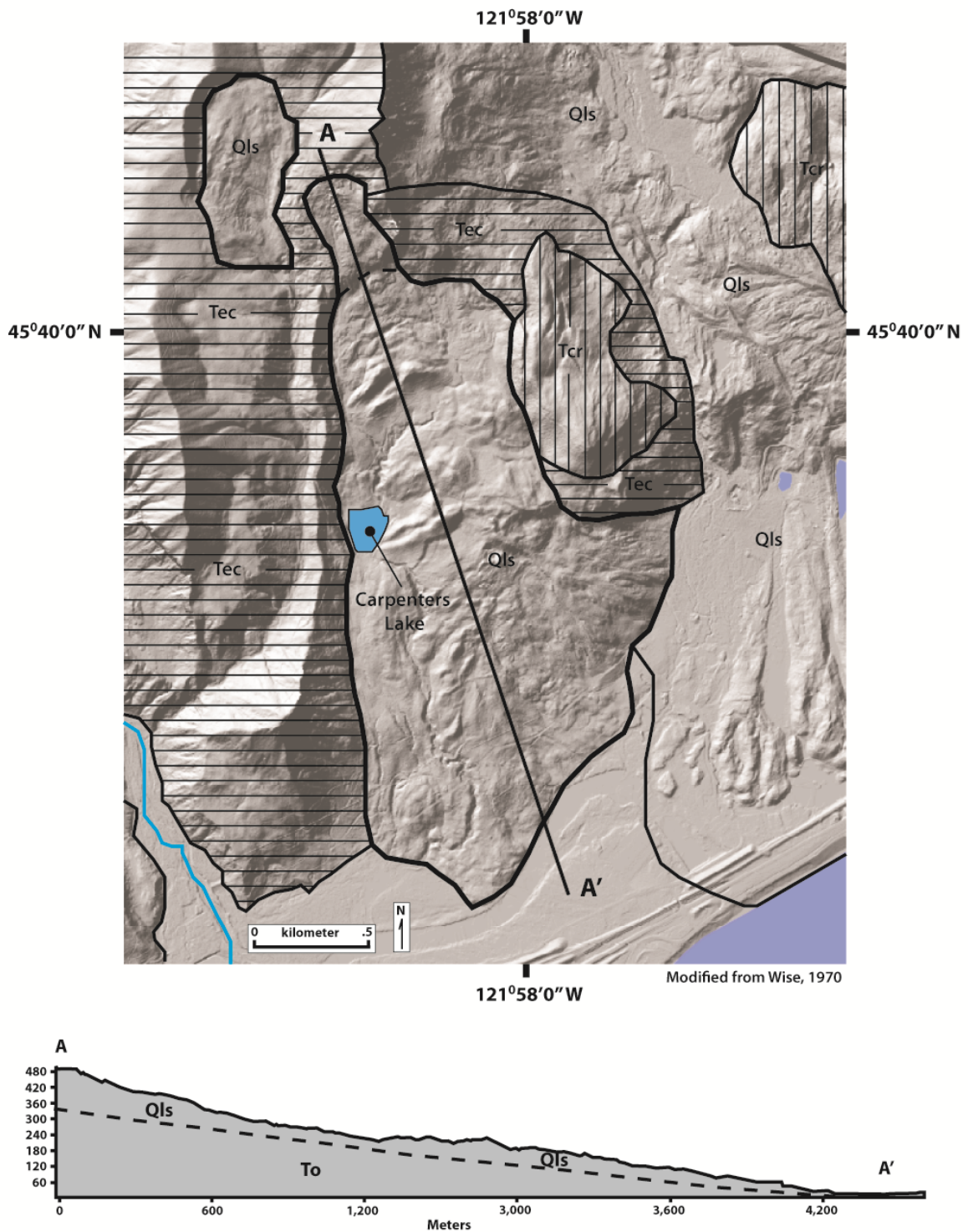

\begin{tabular}{|c|c|}
\hline- Tec - & $\begin{array}{l}\text { Eagle Creek Formation - Volcanic conglomerate and } \\
\text { sandstone tuffs }\end{array}$ \\
\hline Tcr & Dark, fine grain lavas in flows 12 to 30 meters thick \\
\hline Qls & Landslide deposits of Eagle Creek Formation sediments \\
\hline To & $\begin{array}{l}\text { Ohanapecosh Formation - Largely andesitic to } \\
\text { rhyodacitic pyroclastic rocks (primary and reworked } \\
\text { tuffs and lapillistones, and tuff breccias) having } \\
\text { interbedded basaltic flows (Wise, 1970) }\end{array}$ \\
\hline
\end{tabular}

Figure 17. Geology of the $2.75 \mathrm{~km}^{2}$ Carpenters Landslide 


\subsection{Recent Movement}

Until recently and presently, the Williams Northwest Pipeline (NWP) has been involved in the construction and maintenance of a natural gas pipeline through the Cascade Landslide Complex (Figure 6). Before 2007 they apparently became concerned about its movement and contracted Golder Associates Inc. (2009) to assess and evaluate the slide region. Golder Associates recommended a pipeline route north and around all landslides in the area. In the summer of 2010, after receipt of their study, a NWP maintenance crew was on site with heavy equipment inspecting and adding new laser monitoring equipment indicating a continued presence at the location. Movement data from Williams Northwest Pipeline (NWP) is not available to the public. Movement has been detected independently by Interferometric Synthetic Aperture Radar (InSAR) on $8.6 \mathrm{~km}^{2}$ of the Red Bluff Landslide occurring during the winter of 2007-2008 and over
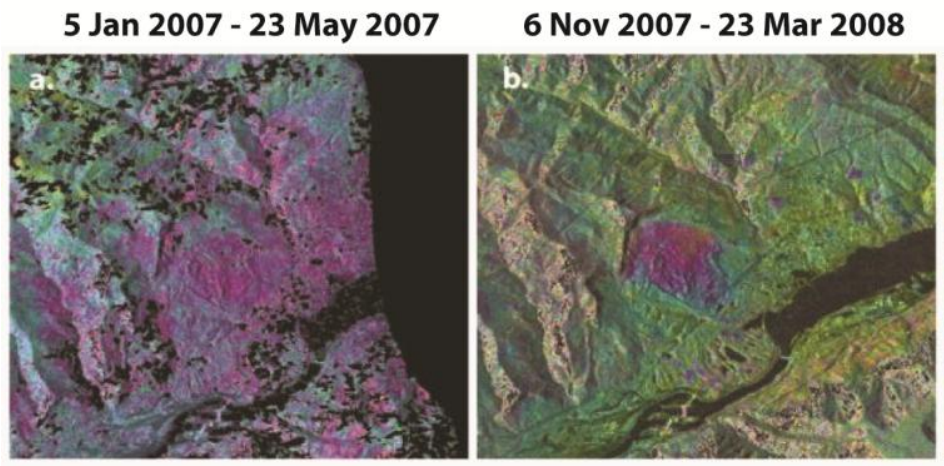

8 Nov 2008 - 8 Feb 2009

Figure 18. a. Pattern gives hint but no definate evidence of ground motion. Images not available for earlier in winter. b. Warm colors grading out to blue and green show location of reactivated part of landslide. c. Area of reactivation has grown slightly. d. Area of reactivation by the Cascade Volcano Obsevatory (Pierson and Lu, 2009). Note: Pixels in image represent 6 to $25 \mathrm{~cm}$ of movement. Greenish pixels indicate no movement while cayenne-colored and purplish blue represent the most and intermediate movements respectively.
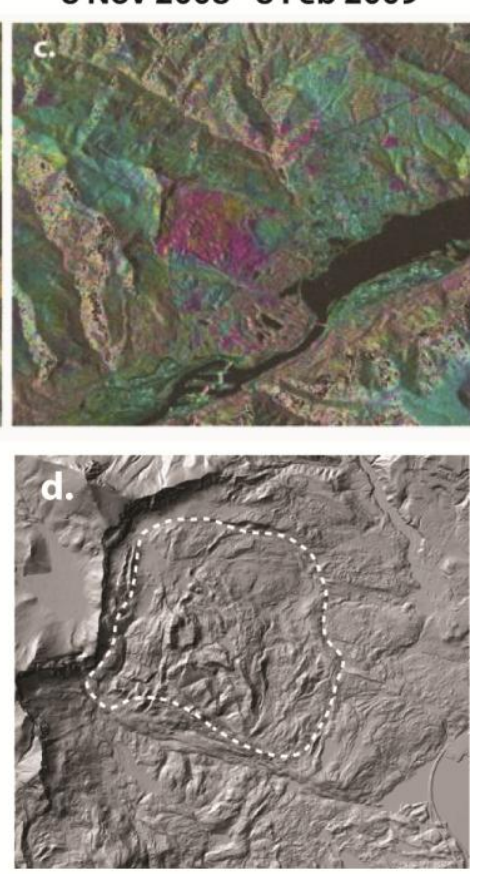
the winter of 2008-2009 (Pierson and Lu, 2009) (Figure 18). The data showed $15-25 \mathrm{~cm}$ of slope-parallel motion from 06 November 2007 to 23 March 2008 and similar movement between 08 November and 08 February 2009 (Pierson and Lu, 2009). InSAR monitoring of the slide is ongoing.

\subsection{1 - Greenleaf Basin Rock Avalanche}

On the southernmost section of the west headwall on the Red Bluff Landslide, the Greenleaf Basin Rock Avalanche occurred on January 3, 2008 (Russ Evarts, U.S.G.S., personal communication, 2008) (Figure 19), and it may have contributed to the recent reactivation of the Red Bluff Landslide (Scott Burns, P.S.U., personal communication, 2008). Evidence of potential failure was first observed on the headwall where tension cracks were observed in the summer of 2007 before the avalanche (Russ Evarts, U.S.G.S., personal communication, 2008).

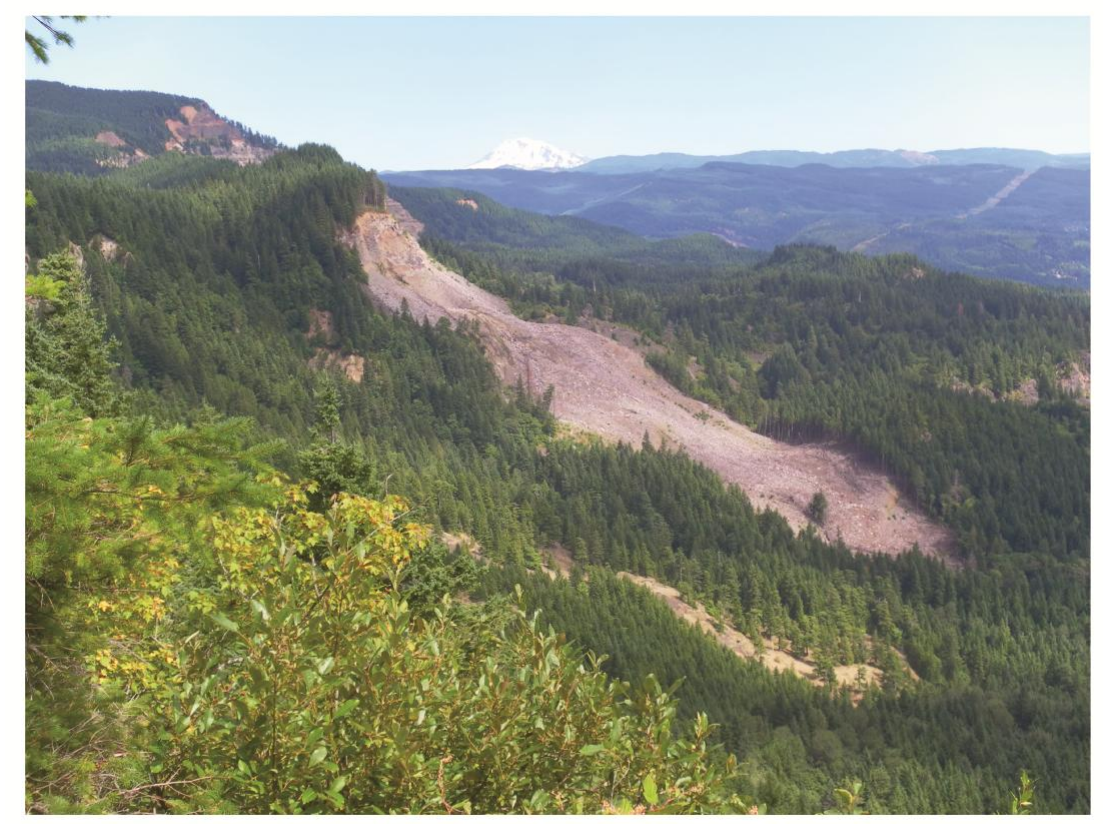

Figure 19. Photo of Greenleaf Basin Rock Avalanche from south flank of Table Mountain 


\section{Chapter 3.0 Methods}

\subsection{ArcGIS/LiDAR/InSAR}

One of the principal methods used to interpret the Red Bluff Landslide was evaluating a $0.6 \mathrm{~m}$ resolution digital elevation model (DEM) provided by the Washington Department of Natural Resources, (DNR, 2007) LiDAR (Light Detection And Ranging) datasets. ArcGIS version 9.0 was used to convert the DEM into a hillshade relief, and contouring was added when needed. In some cases, the DEM was colored to enhance relief. Particularly useful was the "3-D Analyst" ArcGIS tool enabling the creation of surface profiles (cross sections). Headscarp heights and slide volumes were calculated. Selected parts of the slide were digitized.

Landforms are easily seen on LiDAR images, and features of interest were identified and coordinates determined to examine the feature in the field. Soil pit sites were located in this manner. This is also how the blocks of Eagle Creek were first identified and were later field checked with a GPS unit. Printed LiDAR hillshade reliefs with 0.5 to $6 \mathrm{~m}$ (5 to $20 \mathrm{ft}$ ) contours aided field work.

To calculate volumes of the landslide, I used ArcGIS to calculate the area of the digitized perimeter. ArcGIS's "3-D Analyst" tool is then used to generate a profile of that area from which one can estimate the stratigraphy based on the known depth and dip of the saprolite below the Eagle Creek Formation (See section 4.1, page 32).

Radar returns (InSAR) from two satellite flyovers yield amplitude and phase information at each pixel aided in the analysis of the Red Bluff Landslide. With computer software, surface displacements as small as a centimeter can be estimated. 


\subsection{Field Work}

An integral part of this research were field observations and involved reconnaissance for familiarity, followed by ground truthing features identified by LiDAR. Of particular interest were the Greenleaf Basin Rock Avalanche, the climbing and hiking along La Bong Creek, and the investigation on the lower part of the slide where blocks of Eagle Creek sediment were located. I also examined tension cracks on the upper portion of the slide, sag ponds, the andesitic basalt fields from the Red Bluff Volcanoes and observing rockfalls off the headwall. The great portion of the Red Bluff Landslide was only accessible by 4-wheel drive vehicles. As a consequence, my time on site was spent on foot with plenty of challenging hikes and a lot of bushwhacking. A GPS unit (Garmin, GPSmap 60CSx), a compass, relief and contour maps avoided any orientation problems. There were no problems getting into restricted areas. There were a couple of challenges with dogs and 4-wheelers on week-ends that later changed my field work to week days.

Four soil pit regions were selected prior to going into the field using LiDAR basemaps. The purpose was to determine if there were soil differences between the upper and the lower parts of the Red Bluff Landslide and hence an age difference could be determined. Birkeland (1999) states that once colluvium has been deposited and the landscape is stabilized, pedogenic processes operating over time produced soil horizons. Two were selected on the active upper part of the Red Bluff Landslide (U3 and U4), and two were selected below this area (L1 and L2) in the semi-fixed portion of the slide (Figure 20). 


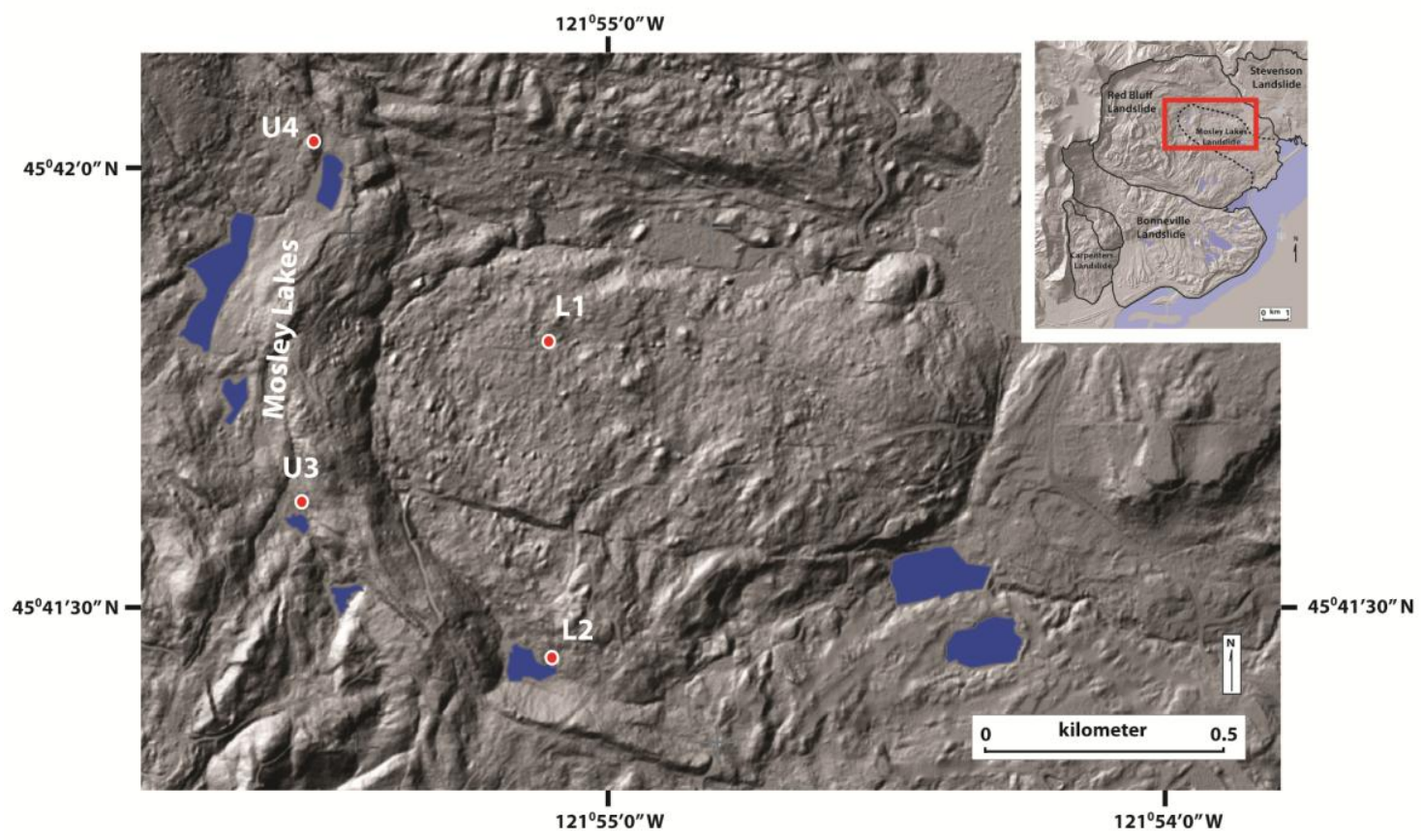

Figure 20. View of the eastern portion of the active upper lobe and the bottom area of the Red Bluff Landslide. Location of 4 soil pits. Soil pit U3 and U4 are on the upper lobe and $L 1$ and $L 2$ are on the lower portion of the slide. All four of these sites are on what was originally mapped as the Mosley Lakes Landslide.

Because the soil pit locations were remote, they were excavated using a small shovel and a rock pick deep enough to get in and get a clear view of the side walls and collect samples from all visible horizons, specifically the B-horizon. The size of the soil pits was approximately $1 \mathrm{~m} \times 1 \mathrm{~m}$ wide ( $3 \mathrm{ft}$. by $3 \mathrm{ft}$.) and at least $71 \mathrm{~cm}(2.3 \mathrm{ft}$.) in depth. Soil samples and textural descriptions were collected from all soil horizons from each of the four excavated soil pits and described using the approach of Soil Survey Staff (2002) and Birkeland (1999). Each soil horizon was described for thickness, texture, structure, consistence, clay films, and horizon boundaries. The two lower pits were dug first, followed by the upper pits. The method used to measure the soil bulk density was digging another small $5 \mathrm{~cm} \times 7.6 \mathrm{~cm} \times 3.8 \mathrm{~cm}\left(2 \mathrm{in} . X 3\right.$ in. $X 1 \frac{1}{2}$ in.) deep holes at the 
bottom of each pit, collect the mass and fill the hole in with water to get the volume (Figure 22). The collected soil mass was then dried in the lab and weighed.


Figure 21. Method of getting densities: a. Small hole excavated to collect soil. b. Same hole is filled with water to get volume.

\subsection{Soil Analysis}

Laboratory analysis of the selected soils included collecting and recording moist and dry colors, USDA texture (Gee and Bauder, 1986) and the particle size grading curve. The Munsell Color guide was used to determine the moist and dry colors. USDA field texture was based on the Birkeland (1999) gradational scale of smoothness and stickiness. Only the B-horizon from each of the selected soil pits was emphasized for comparing pits because the B-horizon is the zone of clay accumulation (Bockheim et al., 1996). The clay content in the B-horizon can be used as an indicator of the age of the soil (Birkeland, 1999). The A-horizon is the zone of decomposition, and no clay is accumulated; therefore, no correlation with age can be made using the A-horizon (Birkeland, 1999). The C-horizon is weathered bedrock or colluvium, so clay contents may reflect residual clay in the original parent material and not clay that has been translocated in the soil over time (Schaetzl and Anderson, 2005). 


\section{Chapter 4.0 Results/Discussion}

\subsection{Active portion of the Red Bluff Landslide}

Hillshade imagery from the LiDAR DEM's enabled me to sort out different topographical features not otherwise seen in the field. The hillshade indicated 2 major differences in the topography with an abrupt change in slope in between them; an upper region with extremely hummocky topography and a lower region with a smoother texture. I have called these regions the upper and lower lobes respectively (Figure 22).

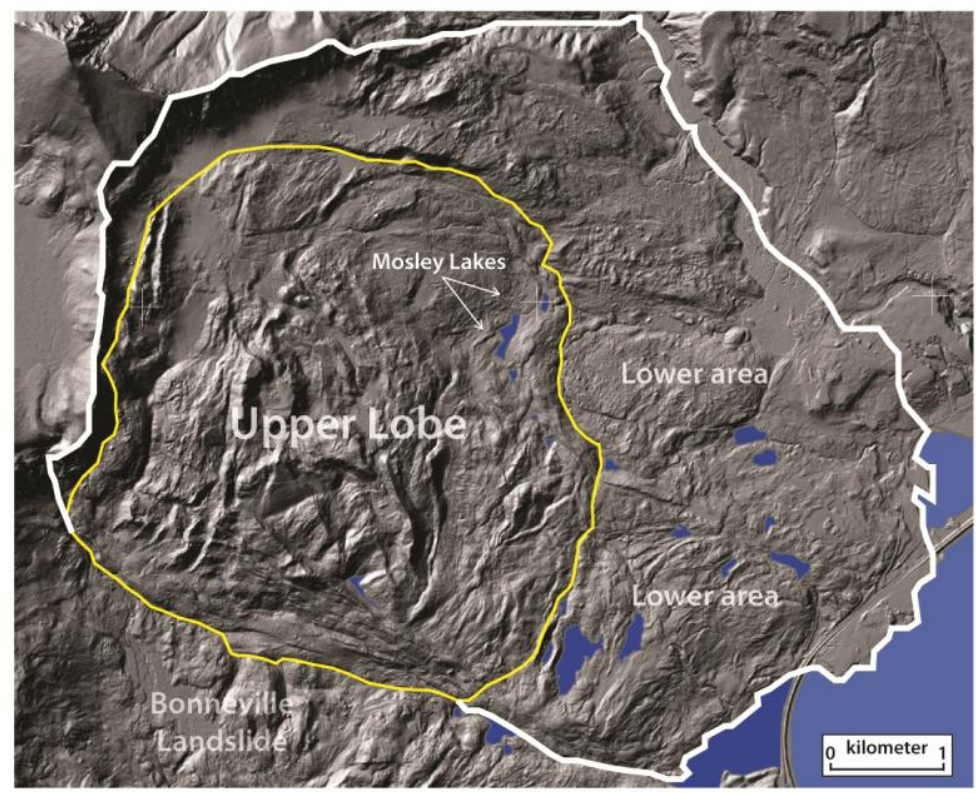

Figure 22. Red Bluff Landslide (White boundary line) Upper lobe (yellow line) and lower area.

My hypothesis states that the Red Bluff Landslide is composed of two parts: an upper lobe that has been creeping on and off, over time, in a southerly direction and spreading laterally over in-place Eagle Creek and/or Ohanapecosh Formations. Other than the interpretation of LiDAR imagery, recent InSAR evidence indicates that it has re- 
activated (Pierson and Lu, 2009) (Figure 23).
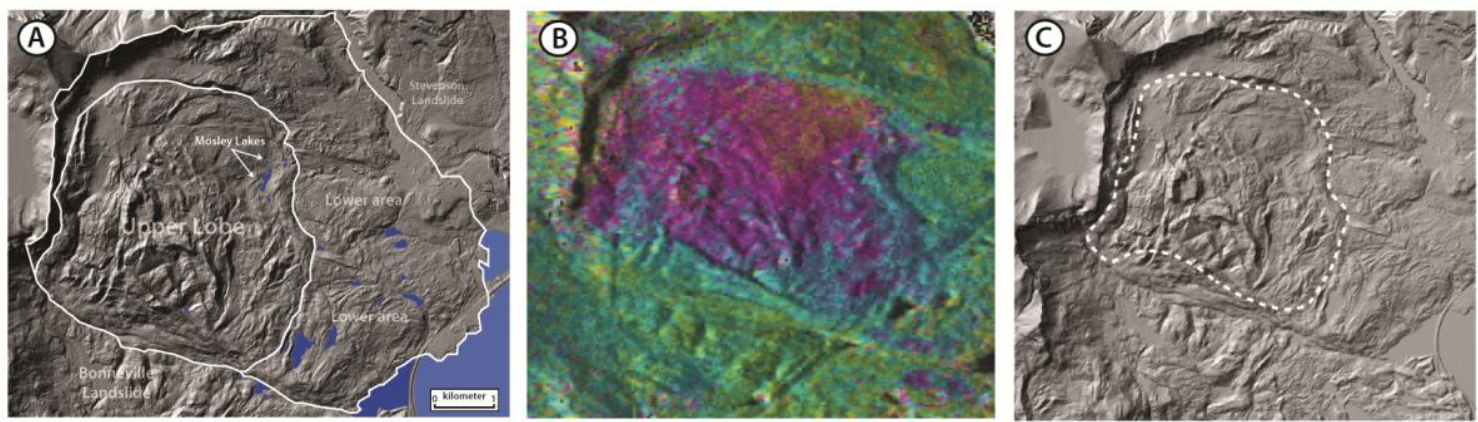

Figure 23. Figures showing the upper lobe and the re-activated area of the Red Bluff Landslide. A. Shows the upper lobe and the lower area of the Red Bluff Landslide. B. A clear indication of the re-activated area on an InSAR interferogram. C. The active area as indicated by the Cascade Volcano Observatory. Images B and C created by Pierson and Lu, (2009)

The hillshade imagery allowed me to see what appeared to be pimple-like

features (hummocks) on the lower part of Wise's (1961) Mosley Lakes Landslide, just

east and below the eastern front of the active area (Figure 24). The hummocks were

investigated and were found to be large

boulders and/or blocks of Eagle Creek

Formation (Figure 24). Russ Evarts (personal

communication, 2011) and I confirmed one

hummock to be Eagle Creek. The

conglomeratic boulders were difficult to

break, were well cemented, but broke apart

around its matrix. There are no visible signs

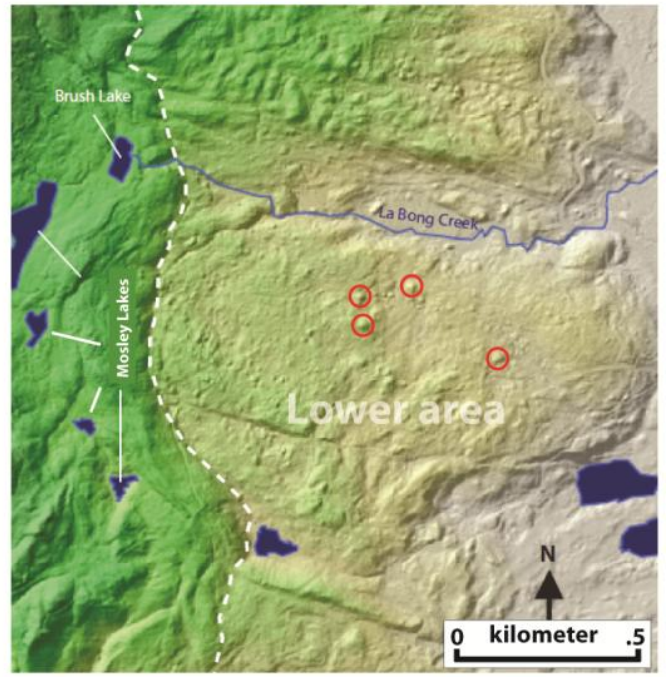

Figure 24. Displaced blocks of Eagle Creek Formation in lower portion of the slide (red circles). White dashed line is border between of alteration. Grain size is larger relative to the upper active area and the lower area.

Ohanapecosh type rocks. These boulders/blocks of Eagle Creek litter the lower portion of the Red Bluff Landslide (Figure 25). Based on the geology of the lower portion of the 
Stevenson Landslide (discussed later), the boulders probably rest on in-place Eagle
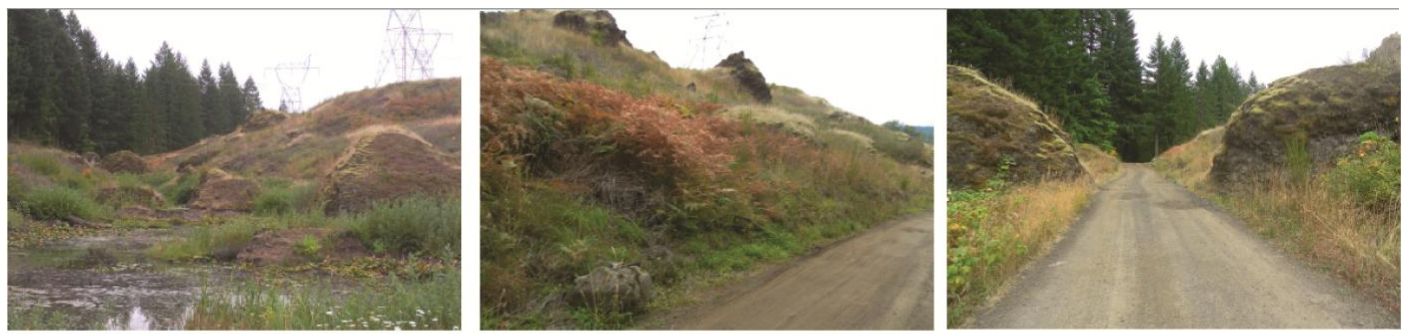

Figure 25. Eagle Creek Formation blocks/boulders litter the lower portion of the slide.

Creek Formation. I conjecture that these Eagle Creek boulders originated from units that have been calved off the main headwall and broken up by Missoula Flood waters (Figure 26).

It became clear during many hikes along the base of the north headwall of the Red Bluff Landslide that the headwall was actively unraveling and probably has been for thousands of years. The Red Bluff Landslide was a progression of failures over time.

During the warm summer

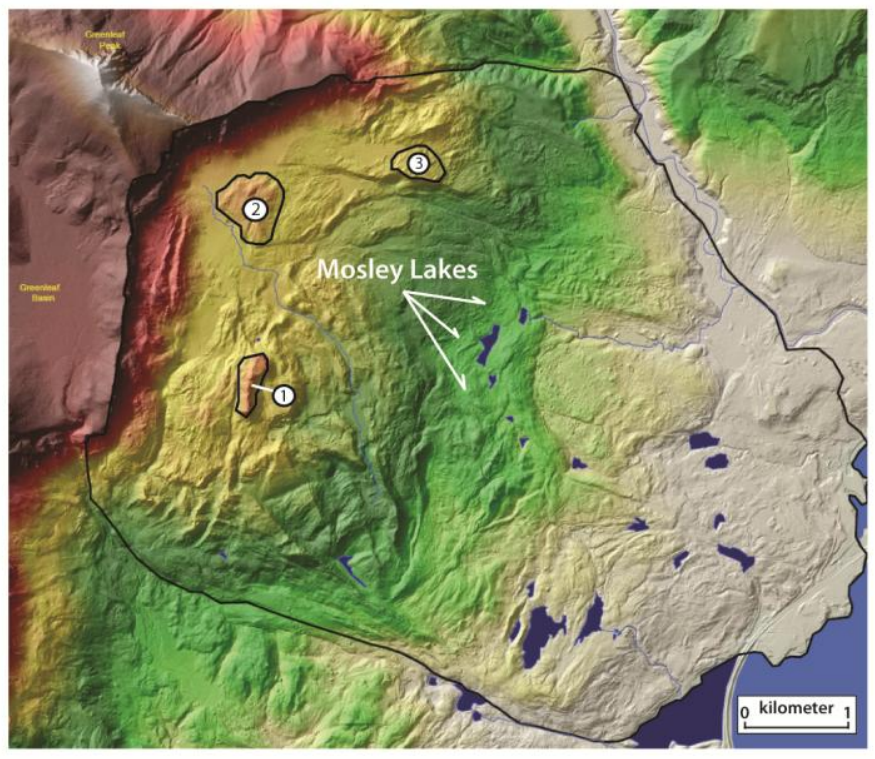

Figure 26. Red Bluff Landslide (black boundary line). Feature 1 is a calved block of Eagle Creek. Features 2 and 3 are identified as Eagle Creek and appear to be in-place.

months near the head wall, cobbles and small boulders are continually heard bouncing and knocking their way down the face of the headwall every 5 to 10 minutes and what seemed to be truck loads 
of debris crashing down less frequently during the day. Local residents report that the activity is much greater in the winter months.

The active portion of the Red Bluff Landslide has an area of 8,245,000 $\mathrm{m}^{2}$ and was divided into four sections to calculate volume. Each of the four sections was measured for that particular area of the upper lobe (Figure 27). A cross sectional line was drawn down the center of each section resulting in four cross sectional profiles. Since an erosional unconformity lies between the Eagle Creek Formation and the Ohanapecosh Formation, an

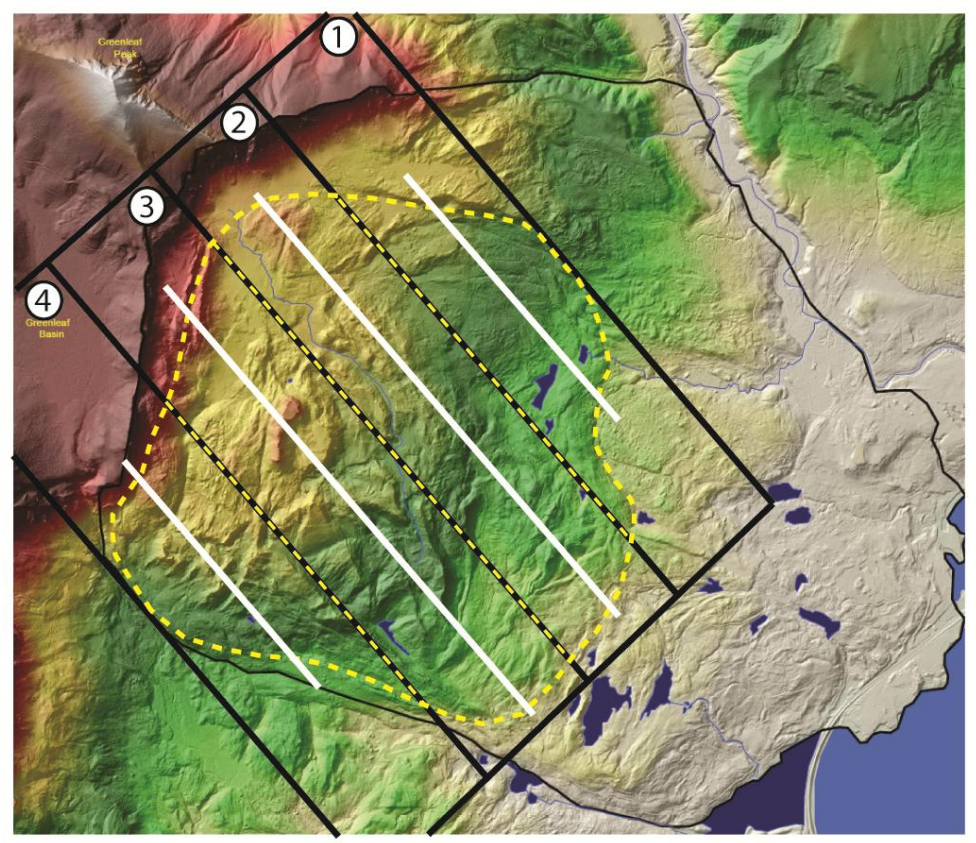

Figure 27. Method to estimate volume of the active upper lobe. Dotted yellow line is active area(s). Heavy black line outlines the four sections. White line is the line representing a generated profile.

average depth was estimated using the arc GIS generated profiles and information from Wise (1961). Wise (1961) said that the slide in front of the Red Bluffs a likely to be 300 to 400 feet thick (91 to 122 meters) based on the $1,600 \mathrm{ft}$. elevation (488 meters) at the base of the Red Bluffs and the elevation of the saprolite at the top of the Weigle formation one mile to the northeast at 1,200 feet (366 meters). The volume for each section is simply the area times the average depth. The four volumes were added up for a final estimated volume of $650,000,000 \mathrm{~m}^{3}$ for the Red Bluff Landslides upper lobe. 


\subsection{Characterization of Major Collapse Events on the Red Bluff Landslide}

The Red Bluff Landslide can be thought of as a slide that is progressively

unraveling with sediment, cobbles and boulders shedding off most frequently, rock

avalanches less frequently, and punctuated by infrequent events where large unit blocks

separate from the west headwall. The Red Bluff Landslide is covered with andesitic

basalt, remnants of collapsed volcanoes with Eagle Creek Formation sediments sifting

through and spreading around the south and east perimeter of the upper reactivated

portion of the slide. A sequence of five major collapse events is defined in Figure 28.

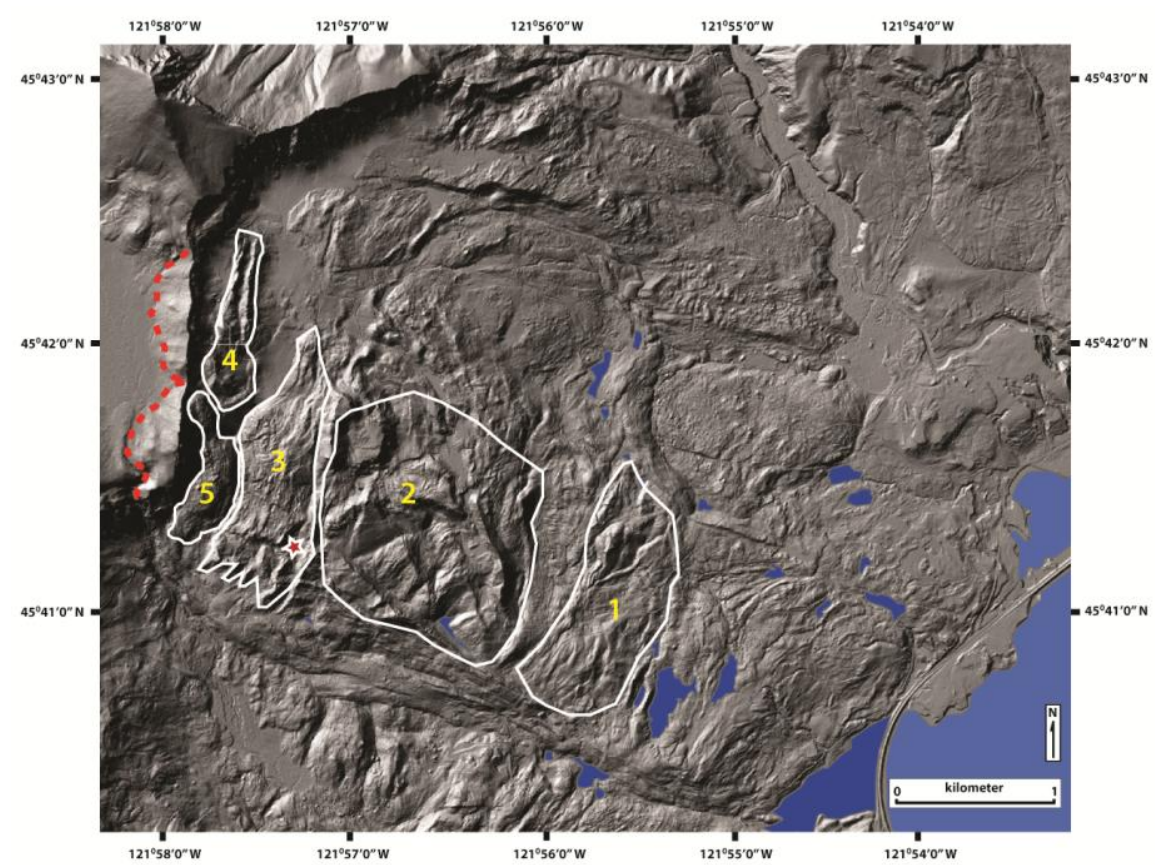

Figure 28. Conceptualized sequence of events of the break-up of the Red Bluff Volcanoes. The first event is the collapse of the eastern flank(s) of the volcano. Event two is different than the rest of the units because it's lineation is to the NW where the others are to the $\mathrm{NE}$. It is probably the biggest event in recent times. Events three, four, and five are the western flank(s). Red star is the location of the neck of the Red Bluff Volcano. Event number five is apparently the last major event that transpired and is the unit upon which the Greenleaf Basin Rock Avalanche flowed over. Red dashed lines are what is remaining of the volcanoes. 
Events three, four, and five are preliminarily identified as post Missoula Flood events. Event number one is suspected to be pre-Missoula Flood based on its separation from the other events and its smoother appearance. Event two may be a pre-Missoula Flood feature and its orientation may have been influenced by Missoula Flood waters. Another possibility for its lineation may have come from the failure of the Bonneville Landslide.

The Red Bluff Landslide can be loosely termed a translational slide as it follows a rough plane identified as an erosional unconformity (Figure 29). The failure plane is likely to be located in a range spanning from the lower parts of the Eagle Creek Formation to the upper parts of the Ohanapecosh Formation and creeping at a rate measured in tens of centimeters per year (Pierson and Lu, 2009). These infrequent collapse events likely span a period of less than 100,000 years based on the 146,000 year age of the Red Bluff Volcano (Russ Evarts, U.S.G.S., personal communication, 2011). Missoula Floods probably washed the slide surface but probably did not get high enough to initiate slide movement (Figure 10).

\subsection{Mosley Lakes Landslide: Non-existent}

Three pieces of evidence lead to the conclusion that the Mosley Lakes Landslide is not a landslide: 1) If Wise's (1961) headscarp (Figures 3, 9, 30) was meant to be lower than where he had drawn it, where the eastern edge of my lobe is, then his head scarp is convex, being steeper at the bottom and shallower at the top, contrary to classical headscarps which are concave and steeper at the top (Cornforth, 2005). Wise's $(1961,1970)$ Mosley Lakes Landslide, as drawn, does not have a scarp; 2) The alleged slide also flows to the east but the overall dip of the Red Bluff Landslide there is to the 

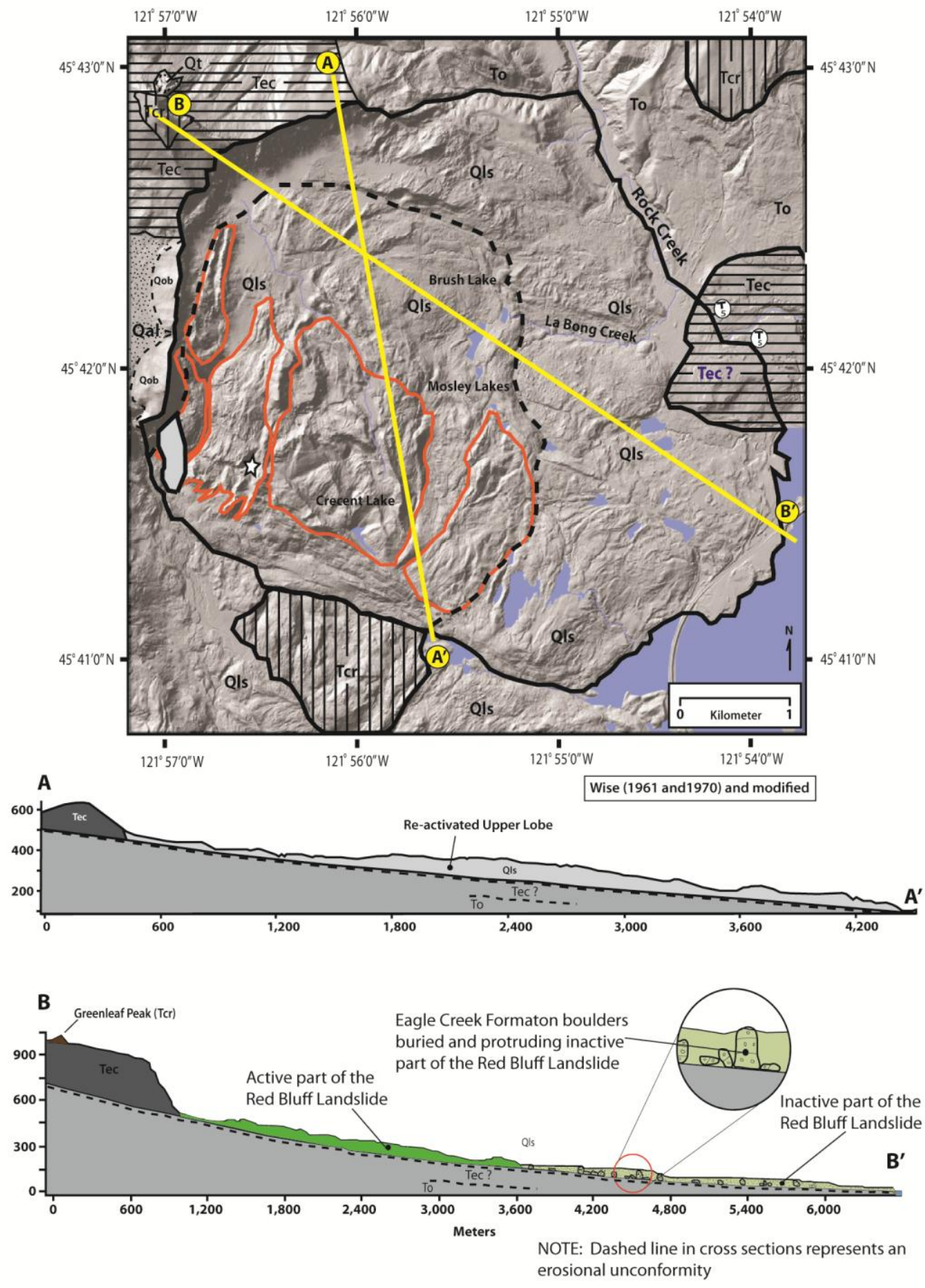

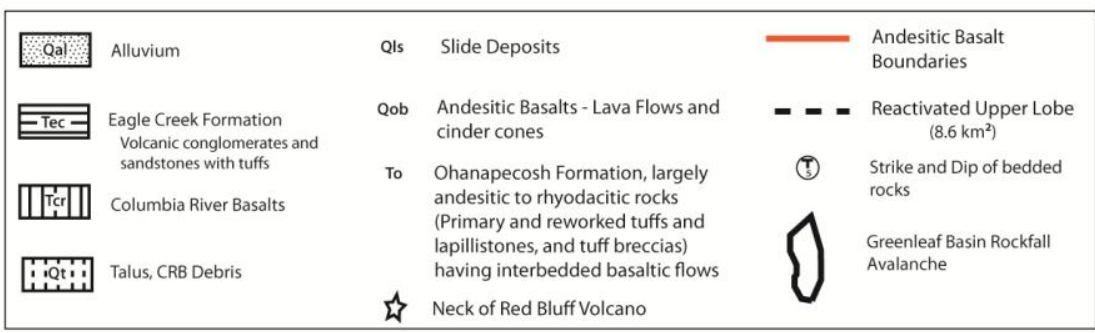

Figure 29. Geology of the Red Bluff Landslide. 


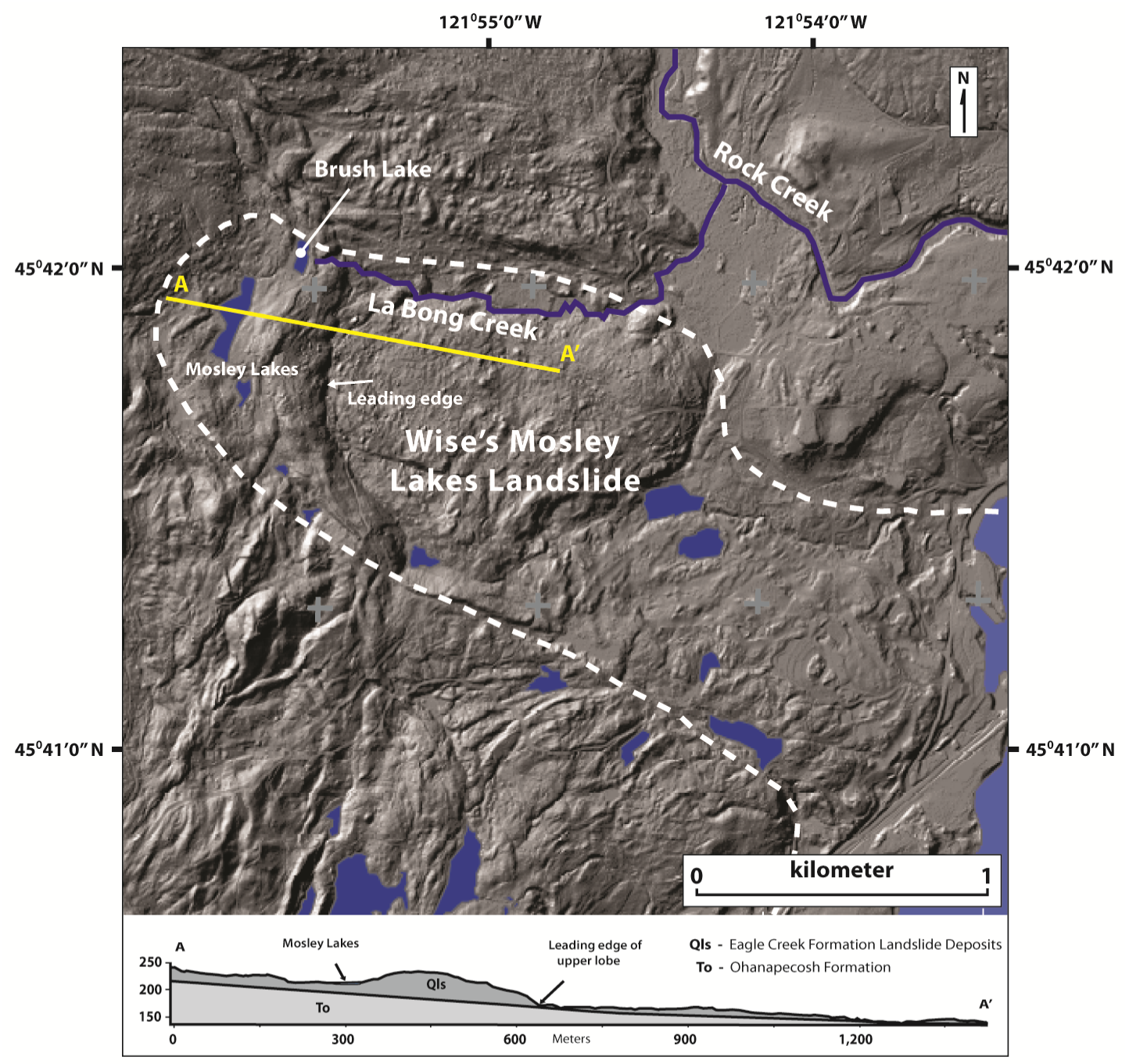

Figure 30. Wise's (1961) Mosley Lakes Landslide (dashed white line) and coss section.

south southeast. 3) The lower portion of the Red Bluff Landslide, east of the re-

activated upper lobe, is a continuation of a dip slope that the town of Stevenson lies upon, an area of inactivity (Figure 31). This dip slope is described by Wise (1961) as entirely underlain by one or more lava flows interbedded with the sedimentary rocks of the Weigle Formation (Ohanapecosh type rocks). 


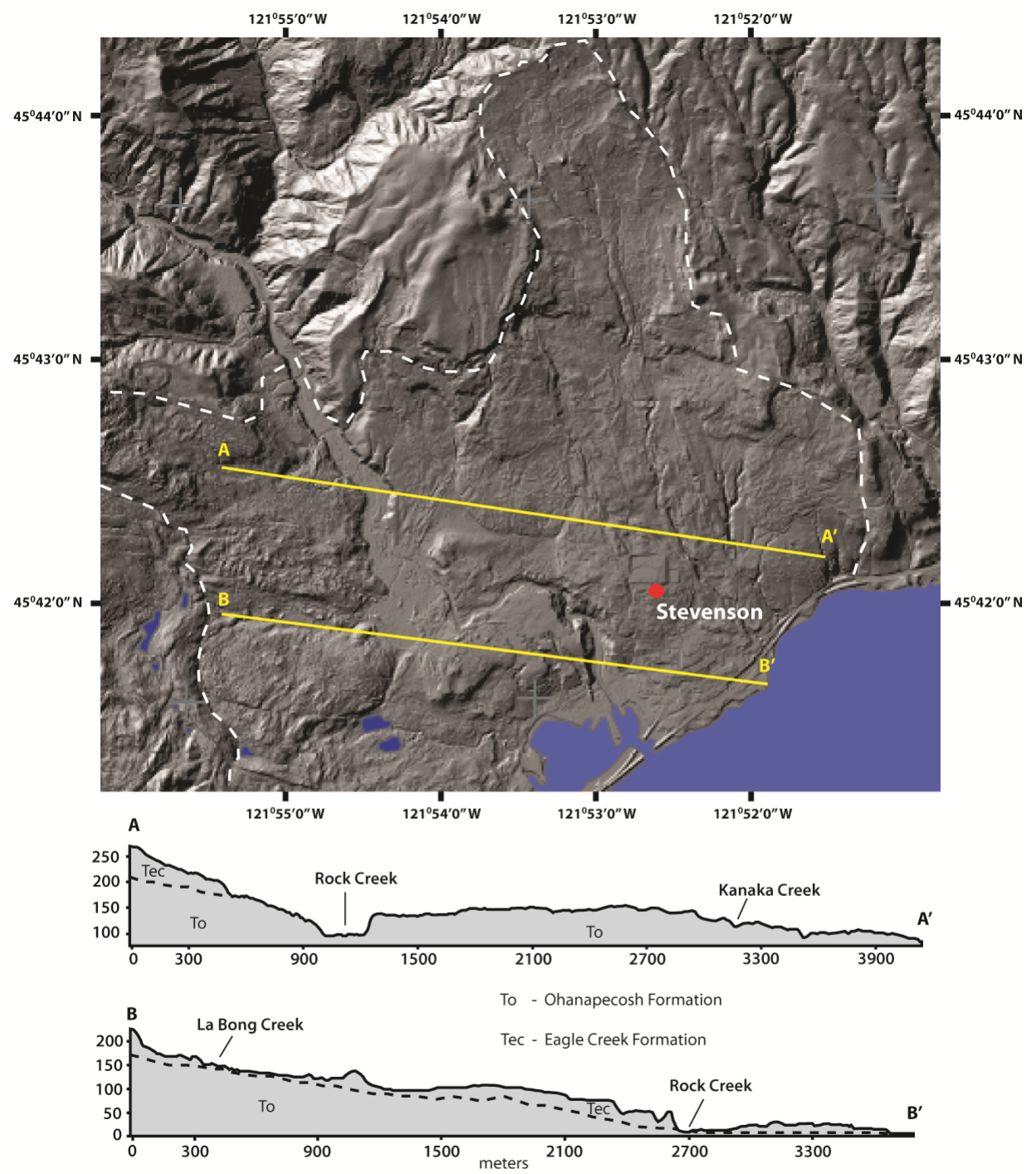

Figure 31. Stevenson dip slope, approximately 7 degrees and described by Wise (1961) as Weigle Formation. Eastern part of the Red Bluff Landslide is part of this dip slope. Cross section A - $A^{\prime}$ and $B$ - B'. Dotted line represents the estimated location of the erosional unconformity.

There appears to be Ohanapecosh type rocks in the La Bong Creek area (Figure 32), an area typified by a thin layer of landslide debris. About a third of the way down from Brush Lake along La Bong Creek's north bank, an apparent Ohanapecosh type outcropping, or a block of it was observed. The rocks were conglomeratic, very dark in color, extremely inundated, and the grain size of the matrix is finer than that of the 
Eagle Creek Formation. If it indeed is Ohanapecosh type rock, it would be the only

exposure of it on the Red Bluff

Landslide.

I argue that the

purported scarp of the former

Mosley Lakes Landslide is in fact

the eastern frontal boundary of

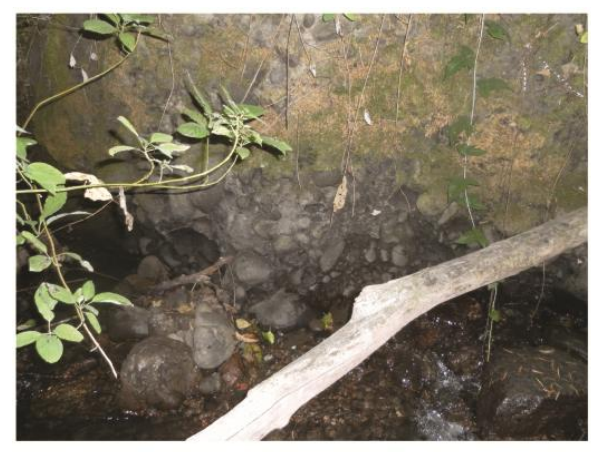

Figure 32. Ohanapecosh type rocks in La Bong Creek.

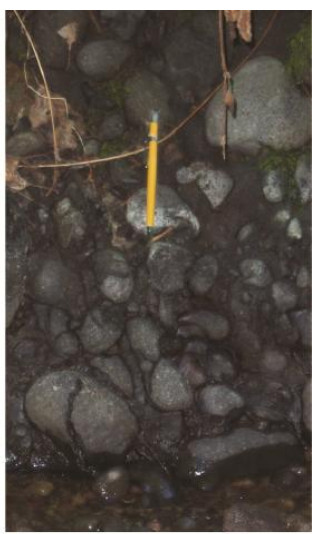

the reactivated upper lobe passing over a surface of the Ohanapecosh type rocks, a

continuous feature that does not stop at the edges of the supposed scarp. Wise (1961)

was a field geologist concerned at the time with the stratigraphy and bedrock geology of the Wind River area. Waters (1973), a mentor and later a colleague to Wise, considered a landslide a "nuisance that hides the bedrock geology". In the case of the Mosley Lakes Landslide, it appears they may not have been accurate in their analysis. This can probably be attributed to the imagery we have today, specifically LiDAR, which has made the difference in recognizing topographic features not otherwise seen before. I propose to stop using the term Mosley Lakes Landslide.

\subsection{Greenleaf Basin Rock Avalanche}

On the southernmost section of the Red Bluff Landslide headscarp, a rock avalanche occurred on January 3, 2008 (Russ Evarts, U.S.G.S., personal communication, 2008). The Greenleaf Basin Rock Avalanche was surveyed (Figure 33), investigated and characterized because it may have contributed to the recent reactivation of the $8.6 \mathrm{~km}^{2}$ reactivated upper lobe of the Red Bluff Landslide (Burns, 2008 personal 

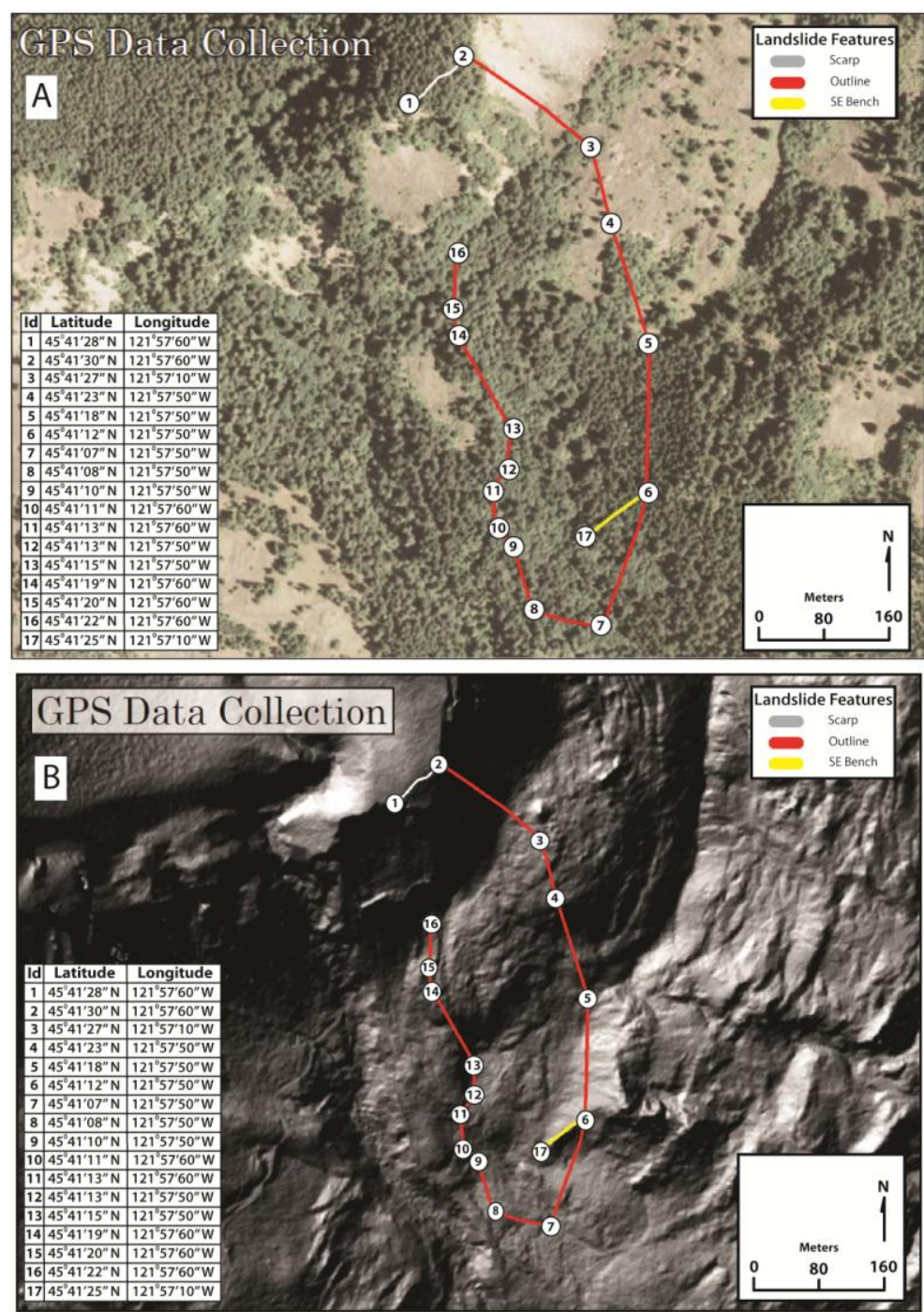

Figure 33. Way points taken of the Jan 3, 2008 Greenleaf Basin Rock Avalanche superimposed onto a 2006 dated orthographic photo (A) and LiDAR image (B).

communication). A tension crack observed in the summer of 2007 by Russ Evarts (2008, personal communication) was the first evidence of potential failure. It separated off the main scarp headwall and collapsed, breaking apart as it hit the base. It flowed easterly 
(Figure 34a) until deflected by a west dipping slope re-directing its flow southward,

where the failure plane intersects the slope (Figure 34b). Figure 34c shows a view from
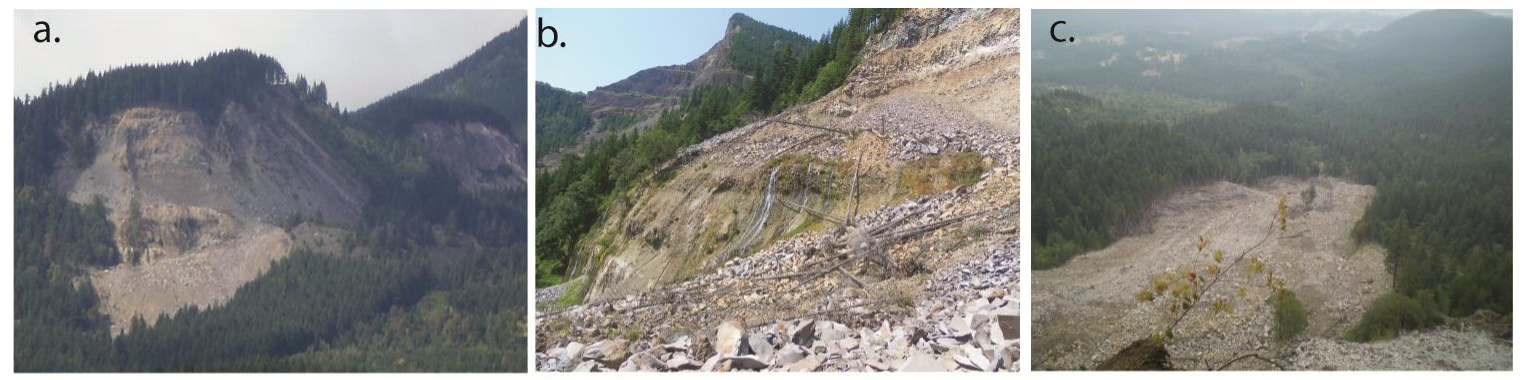

Figure 34. Photographs of the Greenleaf Basin Rock Avalanche. a. Photo looking north from Bonnevile Dam. Note the easterly direction the rock avalanche took at its inception. b. Looking west at the failure surface near the scarp base. Note the water exiting from the apparant failure plane. c. Photo taken form the top of the the headscarp.

the headscarp. From here it took on two separate flows: one down the western part of

the slide and one directly south near the eastern

portion of the slide (Figure 35). The rock avalanche

flowed shearing all trees in its path finishing with

one flow overlapping the other. Most of the rock

avalanche accumulated in a north-south trending

trough close to the eastern perimeter and southern

portion of the slide. Total time from inception to

termination was likely about a minute.

A cross section of the Greenleaf Basin Rock

Avalanche was generated using the "3-D Analyst"

tool in ArcGIS (Figure 36). A scarp length of 105

meters ( $345 \mathrm{ft}$.$) , determined by the measuring tool$

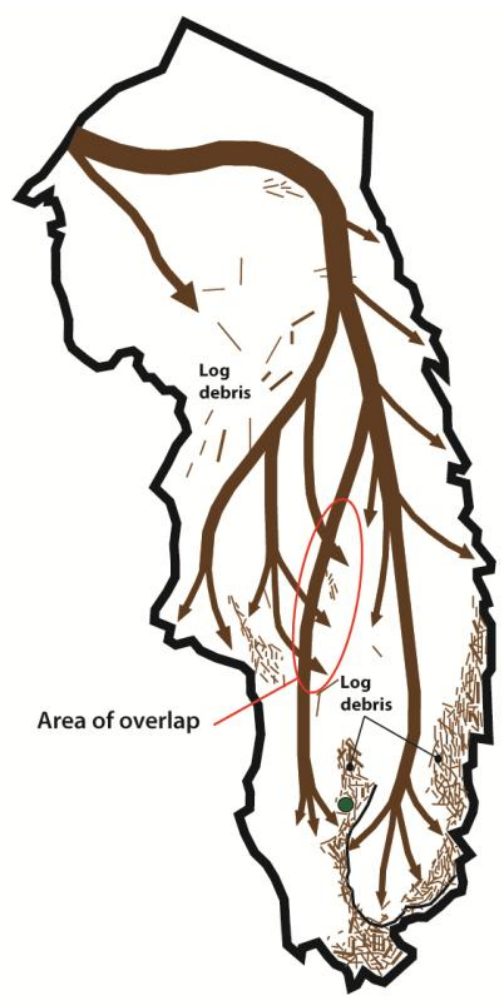

Figure 35. Flow lines for the Greenleaf Basin Rock Avalanche. Green dot represents single surviving tree. in ArcGIS, was known from the data points collected in the field (Figure 33), and the 
elevations were identified by ArcGIS generated contour lines and Figure 36. Its run out length is about $730 \mathrm{~m}$ (2,400 feet) and has an average width of approximately $140 \mathrm{~m}$

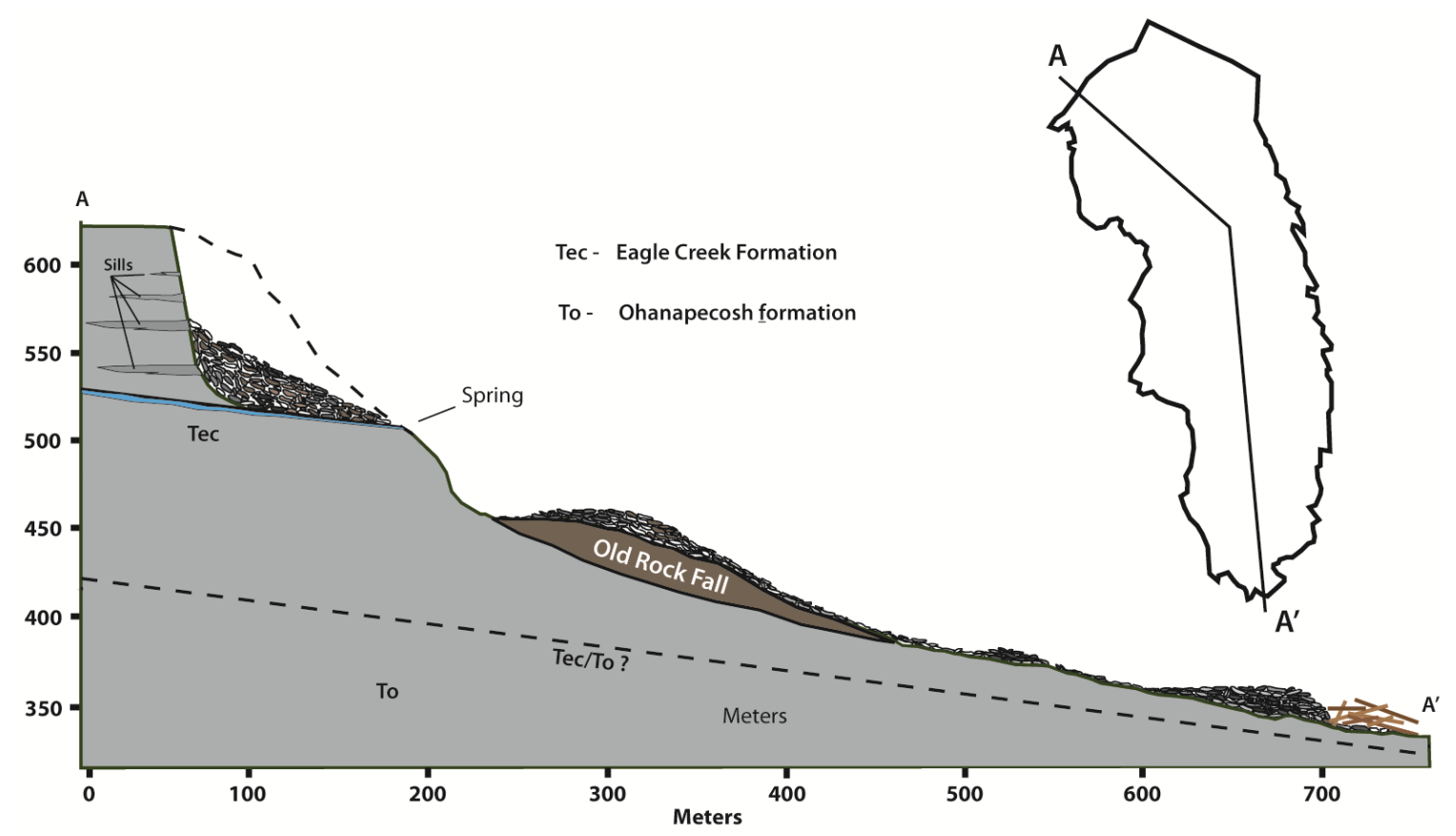

Figure 36. Profile of the Greenleaf Basin Rock Avalanche.

(450 feet). The deposit is made up of andesitic basalt and Eagle Creek sediments covering an area of about $100,000 \mathrm{~m}^{2}\left(1.07\right.$ million $\left.\mathrm{ft}^{2}\right)$. Some areas have accumulated heights of up to 10 meters while other areas are bare of debris. The average depth of

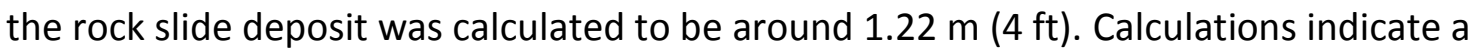
displaced volume of roughly $375,500 \mathrm{~m}^{3}\left(13.2\right.$ million $\left.\mathrm{ft}^{3}\right)$. The displaced volume of the Greenleaf Basin Rock Avalanche represents about $0.058 \%$ of the reactivated volume part of the Red Bluff slide mass (upper lobe) which is $649,862,170 \mathrm{~m}^{\mathbf{3}}(22,949,665,940$ $\mathrm{ft}^{3}$ ) and approximately $0.01 \%$ of the area. A spring fed water saturated layer in the lower part of the Eagle Creek Formation is suspected as the failure surface (Figure 34) inclined at approximately 7 degrees to the south. Eagle Creek sedimentary rocks contain enough 
montmorillonite so that if saturated with water, the overlying weight could be enough to start horizontal movement (Wise, 1961). Although the Greenleaf Basin Rock Avalanche is rather small, we could probably consider this as a sixth event on the Red Bluff Landslide.

\subsection{Old Greenleaf Basin Rock Slide}

The Greenleaf Basin Rock Avalanche flowed over a previous event (event 5 shown in Figure 28), the Old Greenleaf Basin Rock Slide (Figure 37). The old rock slide has a length of approximately 750

$m$ in the northeast

southwest direction

of flow and an

average width of

about $215 \mathrm{~m}$. Its

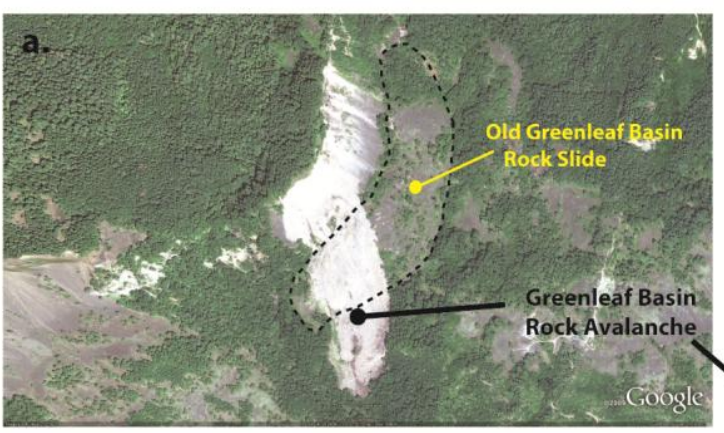

Figure 37. a. Orthographic showing the January 2008 Greenleaf Basin Rock Avalanche flowing over the Old Greenleaf Basin Rock Slide. b. 2007 LiDAR showing outline of Greenleaf Basin Rock Avalanche deposit (red) and outline of Old Greenleaf Basin Rock Slide.

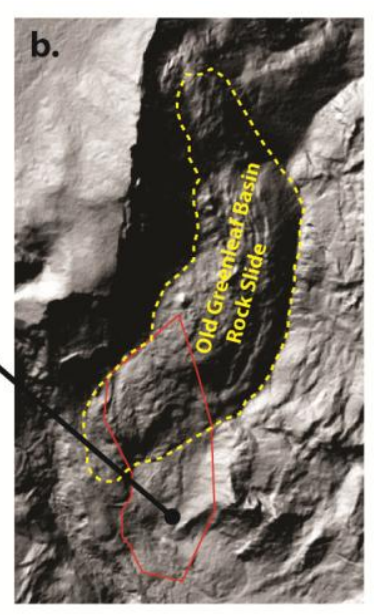

depth was estimated based on a rendition of the profile

before its failure (Figure 36). Its area is about 161,250

$\mathrm{m}^{2}$ and its volume is estimated at approximately 1.9

million $\mathrm{m}^{3}$ based on an estimated depth of $12 \mathrm{~m}$. The

Old Greenleaf Basin Rock Slide is at least 78 years old based on a 1934 Aerial Photo (Figure 38) and estimated to have an age 100 to 150 years based on the

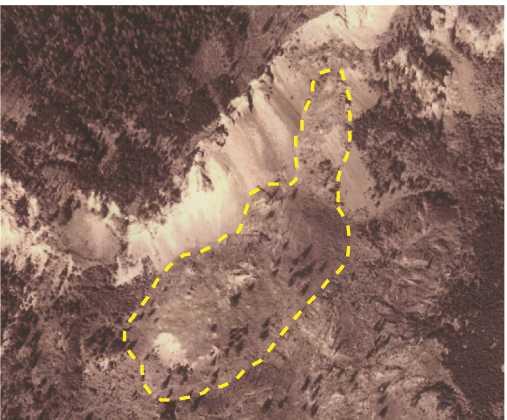

Figure 38. Aerial Photograph taken in 1934 of the Old Greenleaf Rockfall (Yellow dashed line). Aerial Photograph coutesy of the United States Corps of Engineers (USCE) vegetation cover in 1934. 


\subsection{Did Greenleaf Basin Rock Avalanche cause movement to the Red Bluff Landslide?}

The question to whether the Jan 3, 2008 Greenleaf Creek Rock Avalanche event contributed to the overall winter $07^{\prime} / 08^{\prime}$ movement of the slide is uncertain. InSAR interferograms were analyzed from periods 06 November 2007 to 23 March 2008 and 08 November 2008 to 08 February 2009. Figure 39 shows the first flyover was on 06

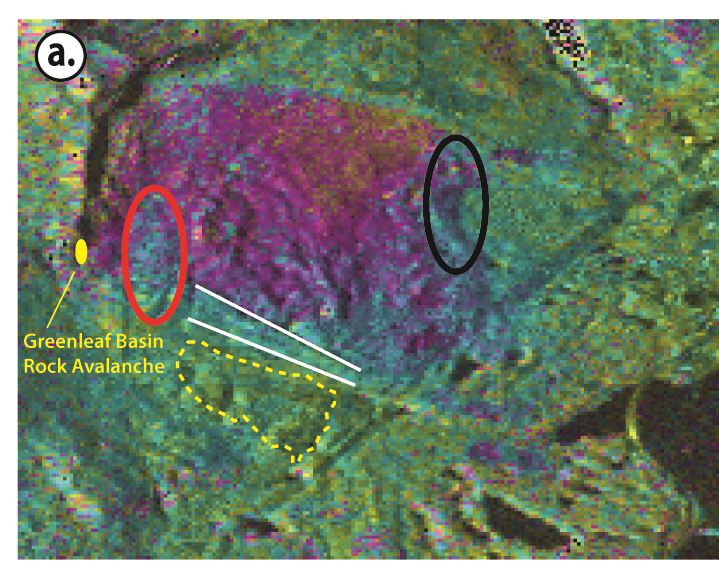

Period from 06 Nov. 07 ' to 23 Mar 08'

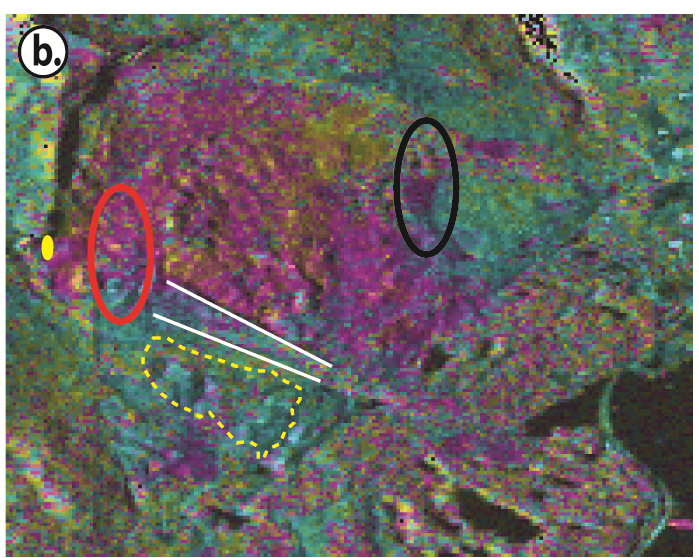

Period from 08 Nov. 08 ' to 08 Feb. 09'

Figure 39. InSAR interferograms for $\mathbf{a}$. winter of $07^{\prime} / 08^{\prime}$ and $\mathbf{b}$. winter of $08^{\prime} / 09^{\prime}$. Yellow dot is Greenleaf Basin Rock Avalanche. Compare the ellipses from one image to the other. One image shows areas of movement while the other shows less movement. White lines outline a compression wedge which is apparently an area of resistance. Yellow dashed line is mapped as basalt by Wise (1961). Images from (Pierson and Lu, 2009).

Nov. 2007 and the second flyover was on 23 Mar 2008. The difference between the two dates yields movements for that period. The greenish pixels represent no movement while the cayenne-colored pixels represent the most movement. The purplish blue represents intermediate movement (Lu, U.S.G.S., personal communication, 2011). The Greenleaf Basin Rock Avalanche occurred on January 3, 2008, the period shown in Figure 39a.

There are distinct differences between the two InSAR images in Figure 39. These differences lead one to sense that movement is differential as proposed in this thesis. 
Some parts move one winter while other parts move the following winter or have moved in preceding winters, dependent on the amount of precipitation that winter. For example, the eastern portion of the reactivated upper lobe shows definite movement winter 08'/09' compared to winter 07'/08' (Black ellipses in Figure 39). The area just east of the rockfall in winter $07^{\prime} / 08^{\prime}$ shows very little movement compared to the movement in winter $08^{\prime} / 09^{\prime}$ (Red ellipses in Figure 39). The southeast portion of the slide in winter08' $/ 09^{\prime}$ appears to be more active relative to the winter of $07^{\prime} / 08^{\prime}$. Both images show movement in the rock slide area, but there is no indication the rockfall was a cause of any movement of the reactivated upper lobe during the period from 06 Nov 07' to 23 Mar 08'.

While driving forces are expected from the north northwest since dip is to the south southeast, the bulk of the slide mass comes off the west wall and is considered to be driving movement of the slide. The Greenleaf Basin Rock Avalanche on the Red Bluff Landslide can be considered as a contributor to driving forces. Resisting forces appear to be a feature resembling a compression wedge at the bottom of the slide backed up by a huge block of Columbia River Basalt on the Bonneville Landslide mapped by Wise (1961) (Figure 3). This compression wedge just north of the basalt shows no movement in either of the InSAR images shown in Figure 39.

While the Greenleaf Basin Rock Avalanche has contributed to the load on the Red Bluff Landslide, it was not the cause of the winter 07/08 movement of the upper lobe. The driver and the principal cause of movement is most likely pore water pressure due to seasonal precipitation (Burns, 2010 personal communication) (Table2). Referring 
$\Theta$

(

()

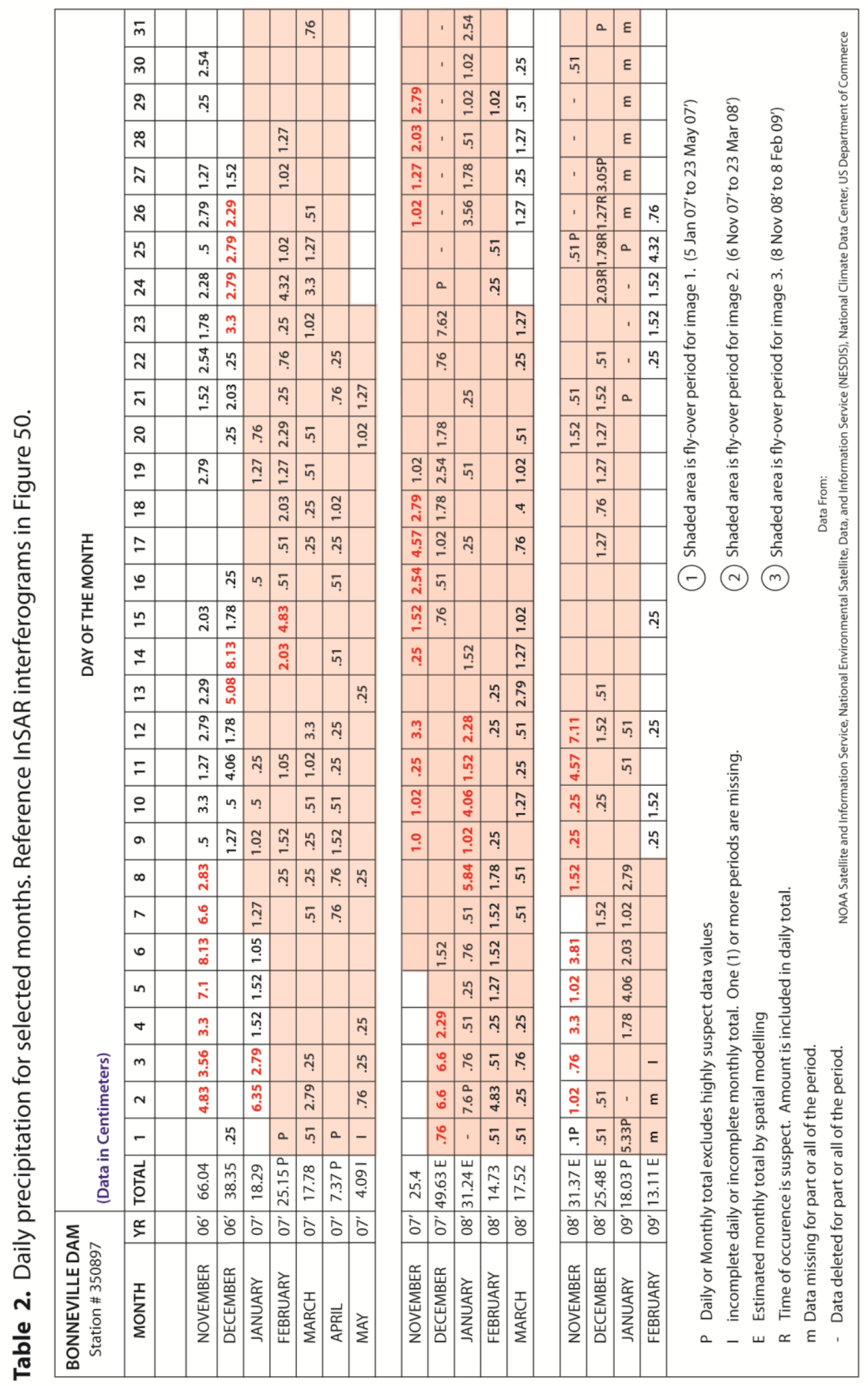


to Figure 40 and Table 2, Figures $40 \mathrm{~b}$ and $40 \mathrm{c}$ interferograms are the first to show any

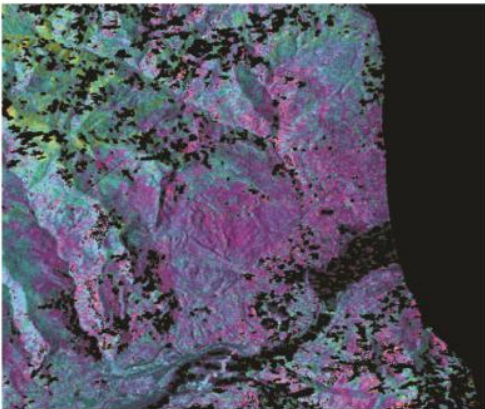

a. InSAR Interferogram for period from 5 Jan 2007 to 23 May 2007 Oblique view from southwest.

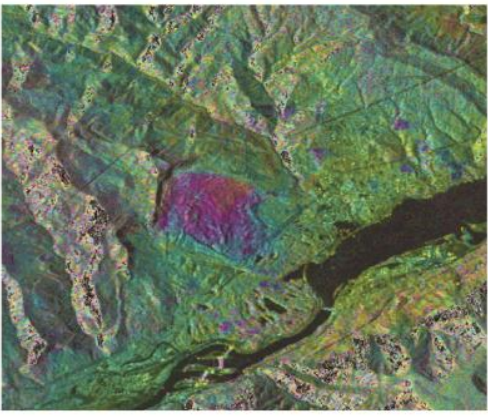

b. InSAR interferogram for period from 6 Nov 2007 to 23 Mar 2008. Oblique view from southwest.

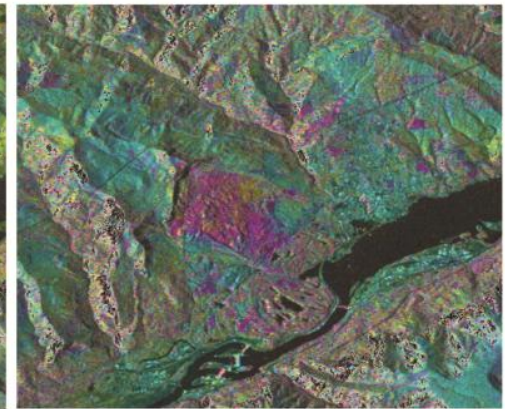

c. InSAR interferogram for period from 8 Nov 2008 to 8 Feb 2009. Oblique view from southwest.

Figure 40. InSAR interferograms from Pierson and Lu (2009)

recordable movement. In the winter of $07^{\prime} / 08^{\prime}$ when November total precipitation was a light $25.4 \mathrm{~cm}$ (10 in), Mid-November 07' indicates an accumulation of $15.75 \mathrm{~cm}$ (6.2 in) of rain in an eleven-day period and a four-day period receiving $7.1 \mathrm{~cm}$ ( $2.8 \mathrm{in}$ ) of precipitation. Early December of $07^{\prime}$ received a three-day period of $16.26 \mathrm{~cm}$ (6.4 in) in a month that received and estimated $49.4 \mathrm{~cm}$ (19.45 in) of precipitation. Towards midJanuary 08', the month of the January 3, Greenleaf Basin Rock Avalanche, $17.73 \mathrm{~cm}(5.8$ in) of precipitation fell in a five-day period. It was a light month with an estimated monthly total of $31.24 \mathrm{~cm}$ (12.30 in). The late November $07^{\prime}$ precipitation event of 7.1 cm (2.8 in) and the early December $07^{\prime}$ precipitation event of $16.26 \mathrm{~cm}$ (6.4 in) can be thought of as a nine-day period bringing in $23.37 \mathrm{~cm}(9.2 \mathrm{in})$.

The image representing winter $08^{\prime} / 09^{\prime}$ recorded the same movement of 15-25 $\mathrm{cm} / \mathrm{yr}$ (Pierson and Lu, 2009) as did the image representing winter 07'/08'. Early November saw an eleven-day period of $21.1 \mathrm{~cm}(8.3 \mathrm{in})$ and there was no precipitation of movement data that were significant in December 08' or January 09'. The rain for the 
months of November through January of winter $08^{\prime} / 09^{\prime}$ were less helpful due to qualifiers included in the data.

If one were to consider movement in winter $07^{\prime} / 08^{\prime}$, it most likely occurred during the late November - early December nine-day period of $23.37 \mathrm{~cm}(9.2 \mathrm{in})$. At this phase of research, we have to pick a maximum rain event to provide the minimum precipitation it would take for movement. One of the drawbacks for InSAR is that we have to accept the times of fly-overs, often months apart, and InSAR has to be used together with rain data to get information on slide movement.

Less significant short term drivers of movement are addition of loads and seismic. It becomes apparent that the Greenleaf Basin Rock Avalanche, 0.058 percent of the total slide mass, was insignificant, and not a driver of movement on the Red Bluff Landslide.

\subsection{Southwest movement of the upper lobe onto the Bonneville Landslide}

Based on morphological features on the southern portion of the active upper lobe, the upper lobe is moving over the Bonneville Landslide. Figure 41 indicates a region of compressional ridges probably caused by an area of resistance mapped by Wise (1961) as a massive block of basalt (Figures 3, 29,39). The overlap and cross cutting features onto the Bonneville Landslide appear to be an extensional features. Jim O'Connor (written communication, 2012) believes the southwest margin of the topographically higher Red Bluff Landslide is 'relaxing' (extending) south into the space resulting from the Bonneville Landslide". One would think that the Bonneville Slide would show cross cutting features over an older part of the Cascade Landslide Complex. 
If one can estimate the original border between the Bonneville Landslide and the Red

Bluff Landslide, one can estimate an average rate of movement since 1450 AD.

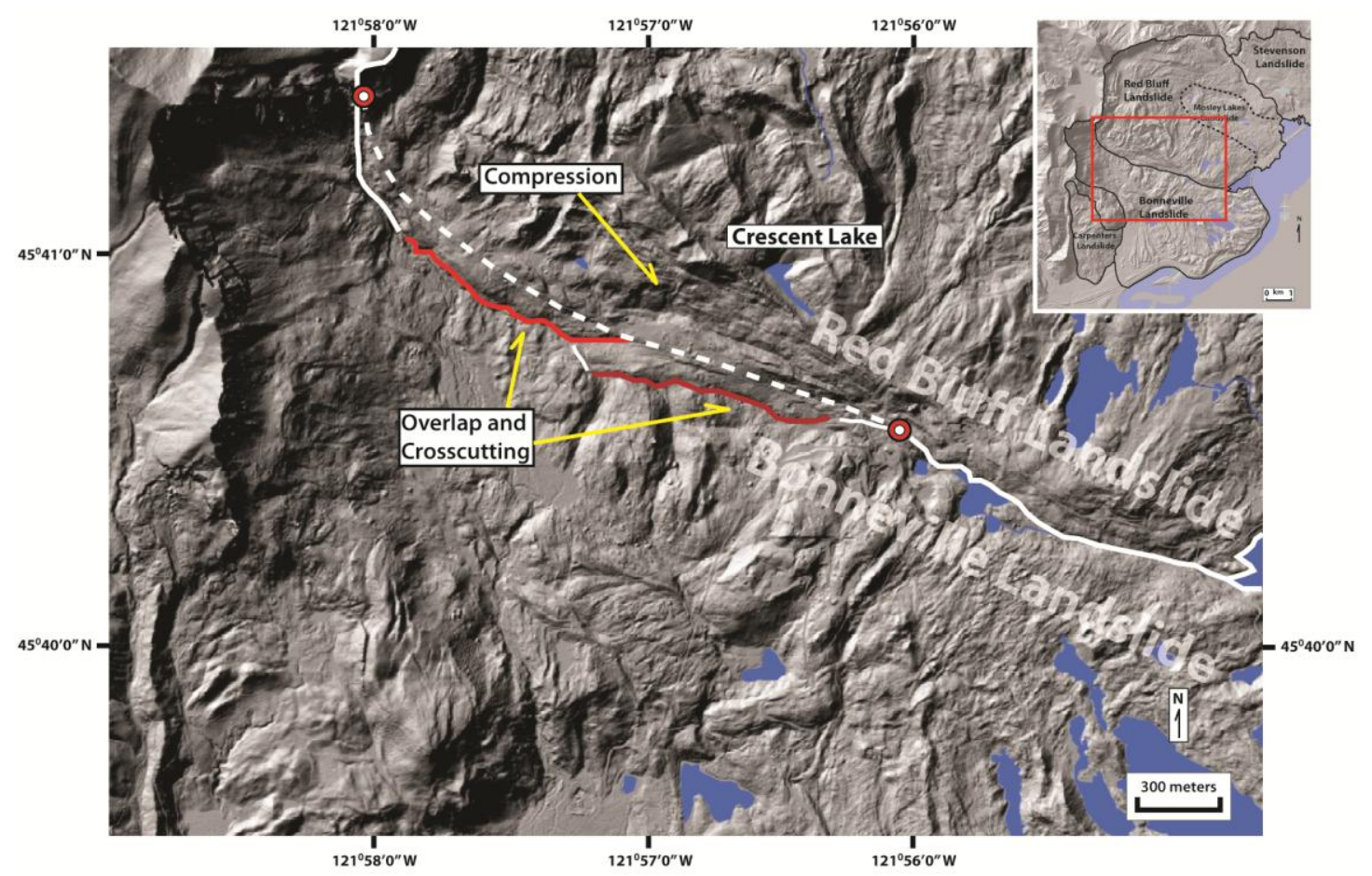

Figure 41. Hillshade relief shows overlap the Red Bluff Landslide has on the Bonneville Landslide. White dashed line is an estimation of where the eastern margin of the Bonneville Landslide was originally after time of failure. Red lines are the maximum extent of the overlap from the Red Bluff Landslide. Compressional, overlap, and crosscutting features indicated. Rate of movement estimated between the red dots.

The original border between the Red Bluff Landslide and the Bonneville

Landslide was interpolated by observations of present day features along the common

border of both slides. For an estimated rate of movement, the upper portion of the border was selected that indicated the most movement. The border was brought in towards the estimated original border position between the red dots as indicated in

Figure 41. Measurements were then taken from tools available in ArcGIS. Based on 560 years that have passed since $1450 \mathrm{AD}$, and a distance of 150 meters from the 
conceptualized original border to the leading edge of the overlap, rate of movement is roughly $25 \mathrm{~cm} / \mathrm{yr}$ in a southwesterly direction.

\subsection{Southeast Movement of the Upper Lobe from West Headwall}

The Red Bluff Landslide possibly took its shape in late Pleistocene time, less than 150,000 years ago, during an interglacial period, when the Red Bluff Volcanoes were fresh, intact, stable, and the main headscarp was considerably closer to the Columbia River. A Red Bluff Volcano has been age dated to 146,000 years (Russ Evarts, U.S.G.S., 2011). During the years of Missoula Floods, flood waters raged through this area scouring out large parts of the region's terrain with heights up to 253 meters ( 830 feet) in elevation. The interpolated height of flood waters passing through the area was 253 meters (830 feet) based on reconstructed water heights at Dog Mountain and Crown Point (Benito and O'Connor, 2003). The flood waters are likely to have reached elevations of up to 267 meters (875 feet) or more in areas such as the north and west headwalls of the Red Bluff Landslide, as the town of Stevenson and the Cascade Landslide Complex locate themselves on the outside bank of the Columbia River.

Before Missoula Flood time, I conjecture that the wall of the head scarp was considerably closer to the Columbia River due to the continual erosion seen today in the unraveling of sediment, rocks, cobbles and eagle creek slide blocks. This is at least true for the north wall of the Red Bluff Landslide. The west wall is different because it sustained a series of failure events of the volcanoes onto the upper lobe (Figure 28). Once the first floods began, they scoured the landslide material off Ohanapecosh type surfaces. The andesitic basalt present then from the collapsed Red Bluff Volcanoes 
(event two - Figure 28) stayed in place during Missoula Flood time as it probably occupied a higher elevation and consisted of large massive boulders. Events three, four, and five are probably post Missoula Flood features. The orientation of event number two suggests that it may have been dislodged, nudged or rotated in a counter clockwise direction. The cross sectional shape of the Red Bluff Landslide most likely took on a configuration as shown in Figure 41.

Large boulders of Eagle Creek Formation litter the slide area, mostly in the eastern portion of the slide and also present themselves as pimples or what has been referred to as hummocky topography on the lower portions of the slide. These are presumably remnants of Eagle Creek Formation slide blocks that have dislodged from the main scarp headwall and have made their way down the slide gravitationally.

Referring to Figure 10, one can see that the town of Stevenson and the Cascade Landslide Complex is on the outside bank of the Columbia River and the interpolated heights of Missoula Flood waters reached the elevations of 253 meters. I believe the flood heights reached up to 267 meters based on the westward trajectory of the Columbia River towards the Red Bluff Landslide. The floods probably did not reach the scarp headwall. The difference between the upper lobe today and the lobe right after Missoula Flood time works out to be approximately 1000 meters (Figure 42). Missoula Floods occurred approximately 15,000 years ago so; the approximate rate of movement of the upper lobe in an easterly direction in the last 15,000 years is an average of one meter every 15 years or an average of $6.6 \mathrm{~cm}$ per year. 
The reactivated portion (upper lobe) of the Red Bluff Landslide today, is almost certainly 15,000 years of accumulated debris from a receding headwall. The Red Bluff Landslide is a work in progress that originally started at the Columbia River, has been receding since late Pleistocene.

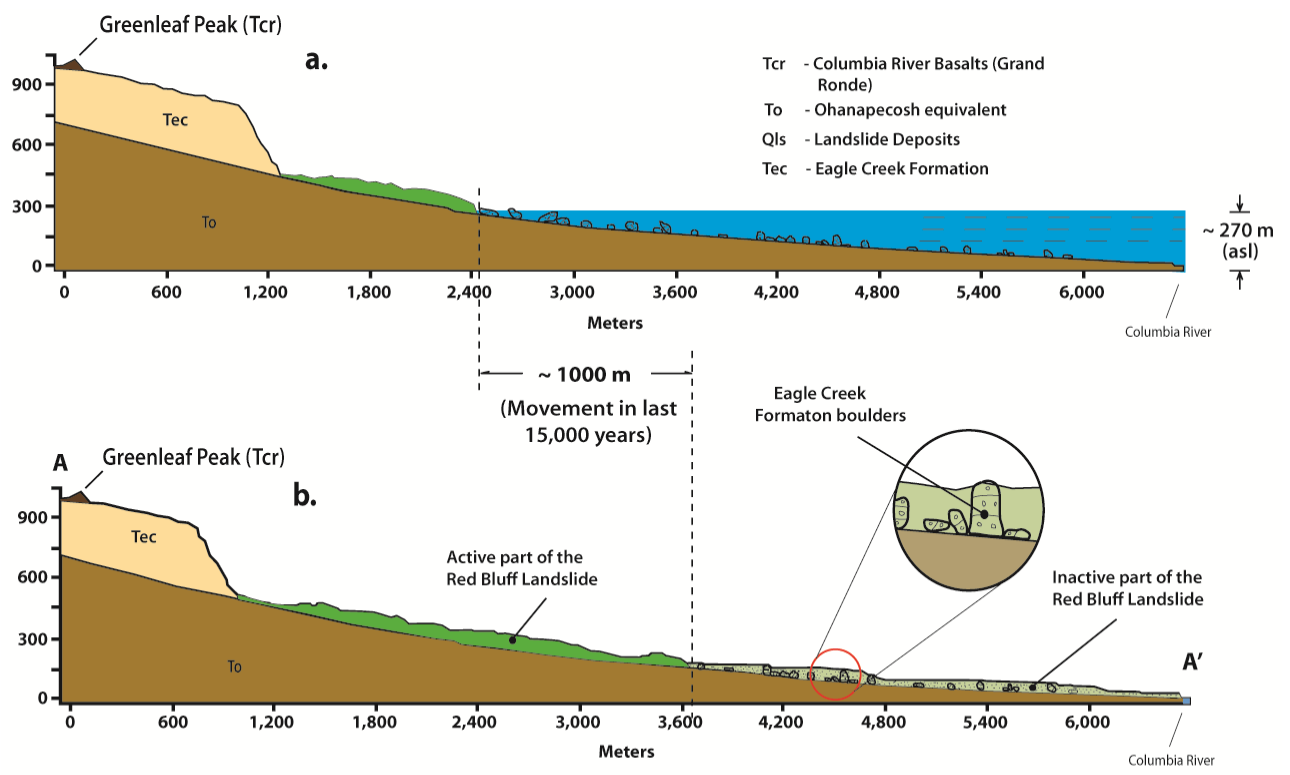

Figure 42. Conceptualized graphic on the evolution of the Red Bluff Landslide.

(a.) During Highest Missoula Floods. (b.) Today (reference Figure 29 for section A - A')

\subsection{Stevenson Landslide}

The area to the east and adjacent to the Cascade Landslide Complex is a dip slope identified by Wise (1961). It is defined by Wise (1961) as underlain by one or more lava flows interbedded with the soft sedimentary rocks of the Weigle Formation. In other words it is an Ohanapecosh surface and extends northward for a total length of about $6 \mathrm{~km}$ from the Columbia River (Figure 43). It had to have, at one time, carried an overburden, slipped into the Columbia River, and the evidence was lost in time. The surface is likely to have been exposed in the Pleistocene based on the lack of any 
evidence. A lineation of a series

of scarps indicated in Figure 44

probably occurred and formed

coincidently at the maximum

flood level during Missoula Flood

time. Emanating from these

headscarps is visual evidence of

up to five flows down towards

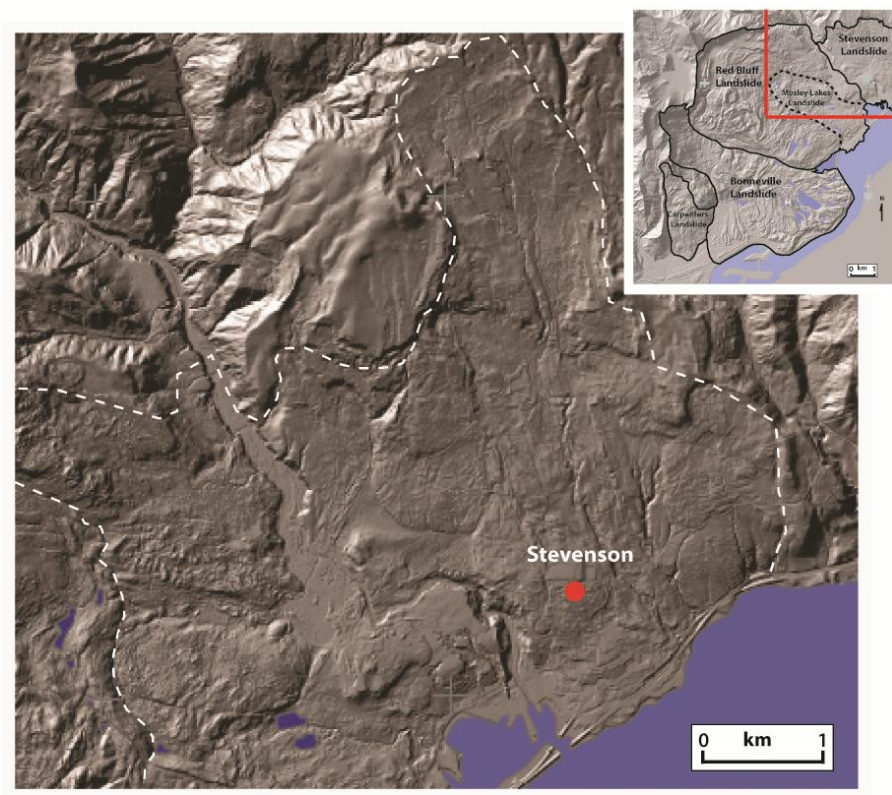

the Columbia River. A close look

Figure 43. Dip slope outlined by white dashed line

at the area indicates the scarps on the dip slope of the Stevenson Slide area extend into

the Red Bluff Landslide forming a continuous feature with the flow and trajectory of

Missoula Flood waters (Figure 44).

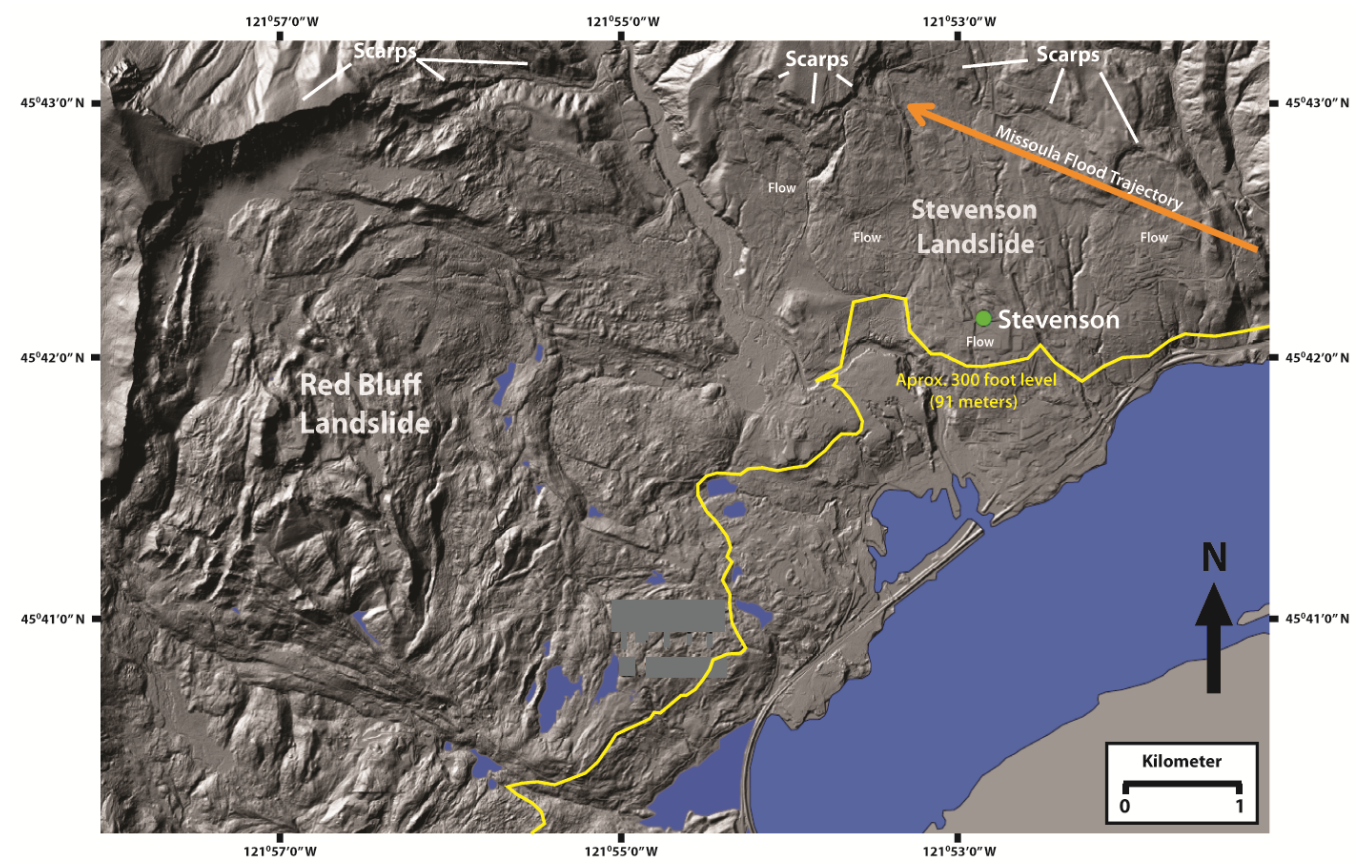

Figure 44. Shaded relief with indicated post Missoula Flood features. Yellow line is the approximate 300 foot (91 meters) level reached by "Lake of the Gods" right before the breaching of the Bonneville Landslide induced dam. Orange line represents probable Missoula Flood trajectory. 
The dip slope also appears to extend into the lower portion of the Red Bluff Landslide. The lower portion of the Stevenson Landslide was mapped by Wise (1970) as in-place Eagle Creek Formation (Figure 45) and can probably be carried over onto the Red Bluff Landslide based on the local topography and a feature that appears to continue on to the Red Bluff Landslide. It is my judgment that the lower portion of the Red Bluff Landslide is probably mostly in-place Eagle Creek Formation with a thin veneer of overlying Eagle Creek landslide debris. Outcrops of Eagle Creek Formation on the Red Bluff Landslide are difficult to identify because the slide is covered by debris and outcrops that seem to be Eagle Creek Formation are most likely to be transported blocks or boulders that have originated off the headwall. The only outcropping of Ohanapecosh Formation appears to be along La Bong Creek (Figure 32).

I have included the "Stevenson Landslide" as an addition to the Cascade Landslide Complex and have called this area the "Greater Cascade Landslide Complex" (Figure 46), the upper boundary being the lineation of scarps (Figure 44) and defined in (Figure 45).

In my judgment, you cannot separate the Stevenson Landslide from the Cascade Landslide Complex. There is too much of a relationship there. First they are adjacent to each other. Secondly, in my view, the Red Bluff Landslide and the Stevenson Landslide share two things that are common to each other: they apparently share the same geology in the southern portion of each slide and seem to share Missoula Flood features that are continuous to each other. They also share a chronological relationship and are related to each other in a process (sec. 4.11). 


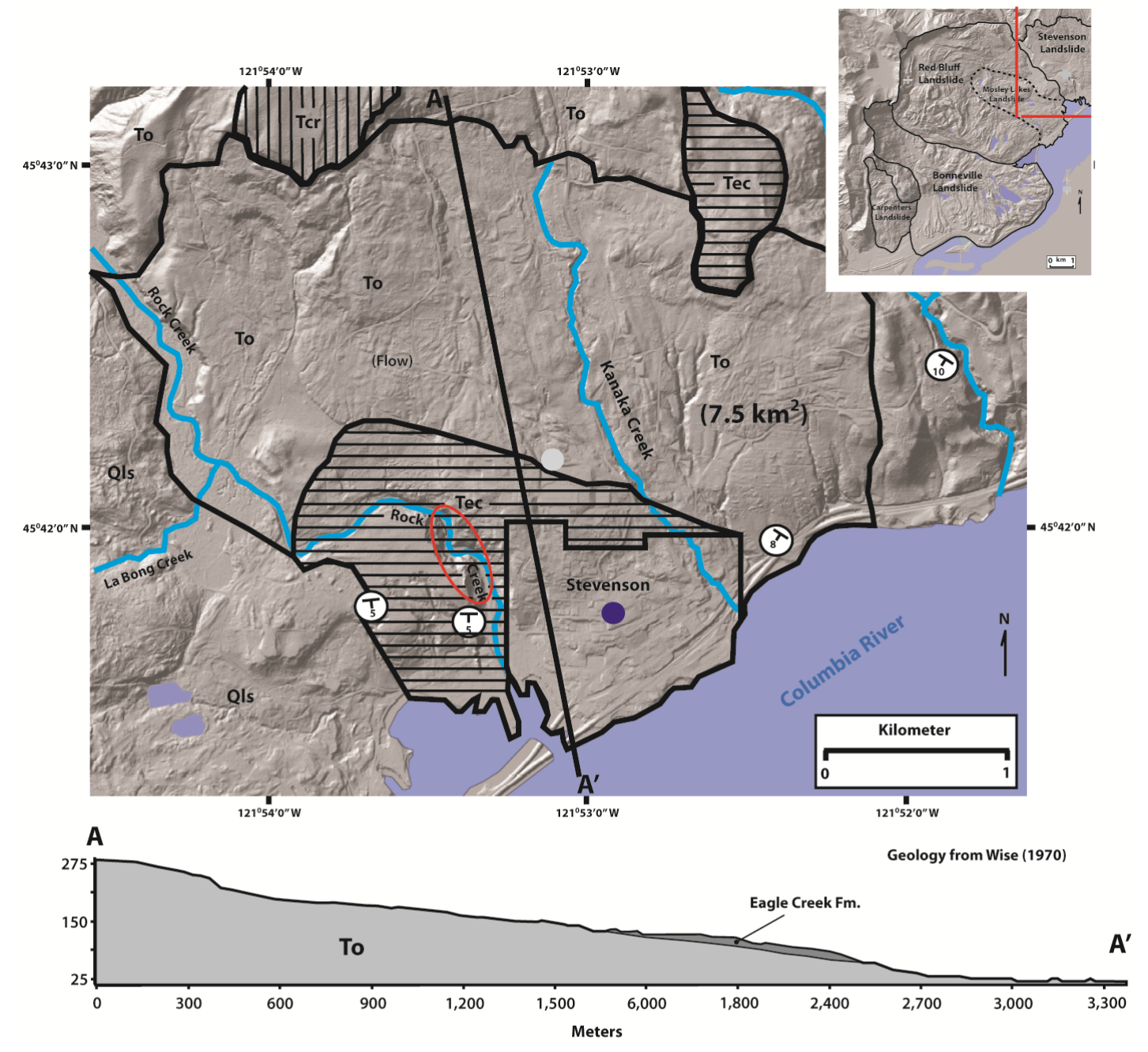

- Tec - Eagle Creek Formation - Volcanic conglomerates and sandstones with some tuffs

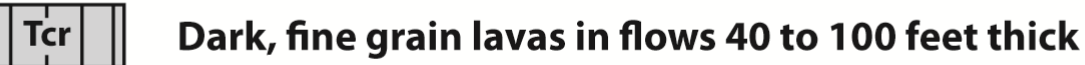

To Ohanapecosh Formation - Largely andesitic to rhyodacitic pyroclastic rocks (primary and reworked tuffs and lapillistones, and tuff breccias) having interbedded basaltic flows (Wise, 1970).

\section{QIs Quaternary landslide deposits}
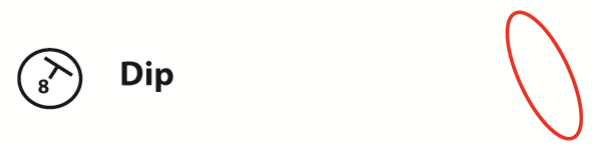

2007 reactivation area (Rock Creek) of the Stevenson Slide

Figure 45. Geology and cross section of the Stevenson Slide. These units may explain the geological makeup of the landslide deposits on the lower portions of the Red Bluff Landslide. 


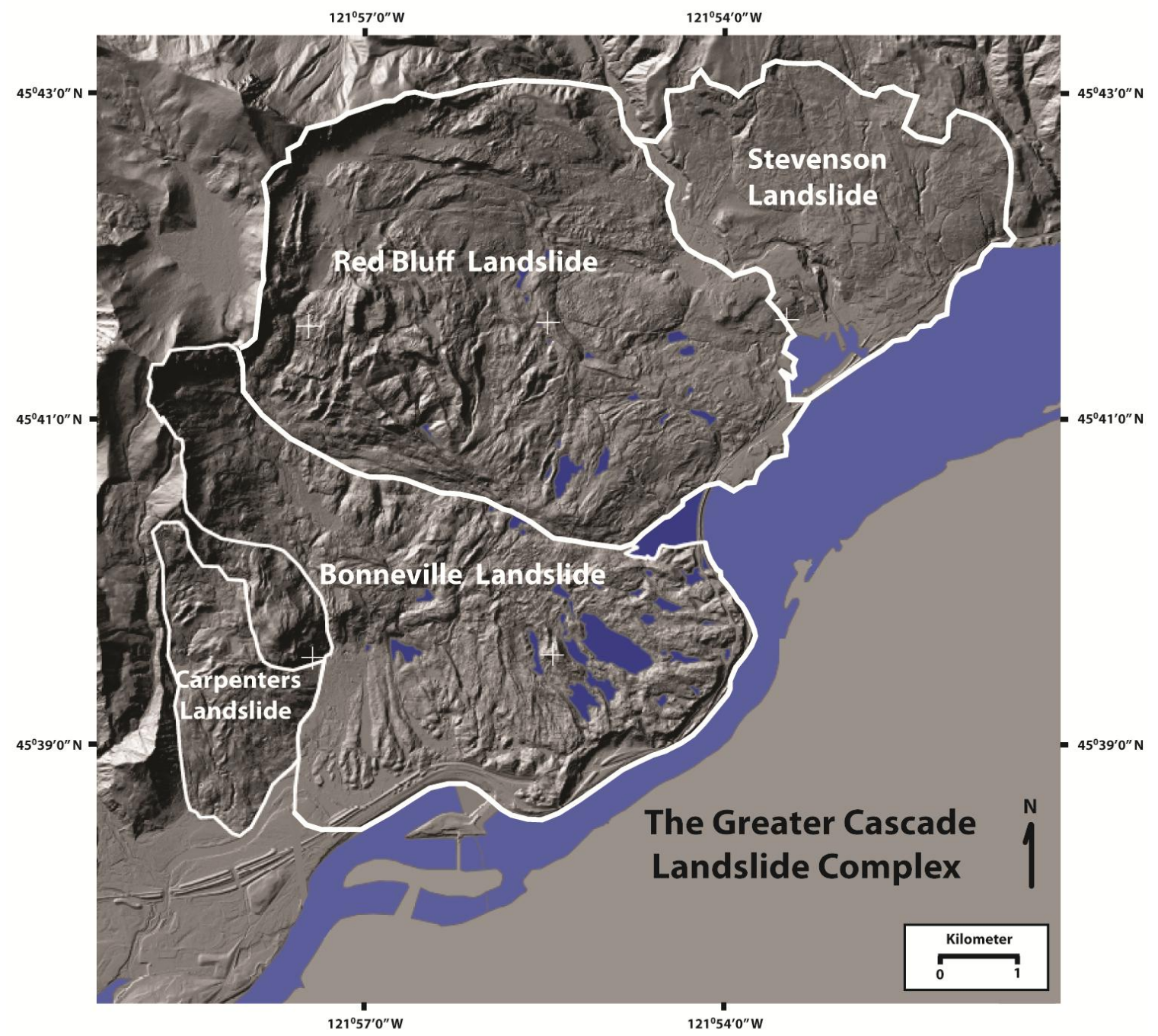

Figure 46. The Greater Cascade Landslide Complex $\left(43.0 \mathrm{~km}^{2}\right)$ and members: The Carpenters Landslide, Bonneville Landslide, Red Bluff Landslide and the Stevenson Landslide.

\subsection{Reactivation of the Stevenson Slide at Rock Creek}

The Stevenson Landslide is not without risk as it is being undermined with landslide activity at Rock Creek (Figures 47 and 48), on the lower portion of the Stevenson Landslide (Figure 45). The Rock Creek Slide has been characterized as sediment failing over an Ohanapecosh surface into Rock Creek presenting a problem for the town of 
Stevenson. The Ohanapecosh in this location is also being cut through, forming the walls along Rock Creek. It has been seasonally active and has taken out quite a few homes
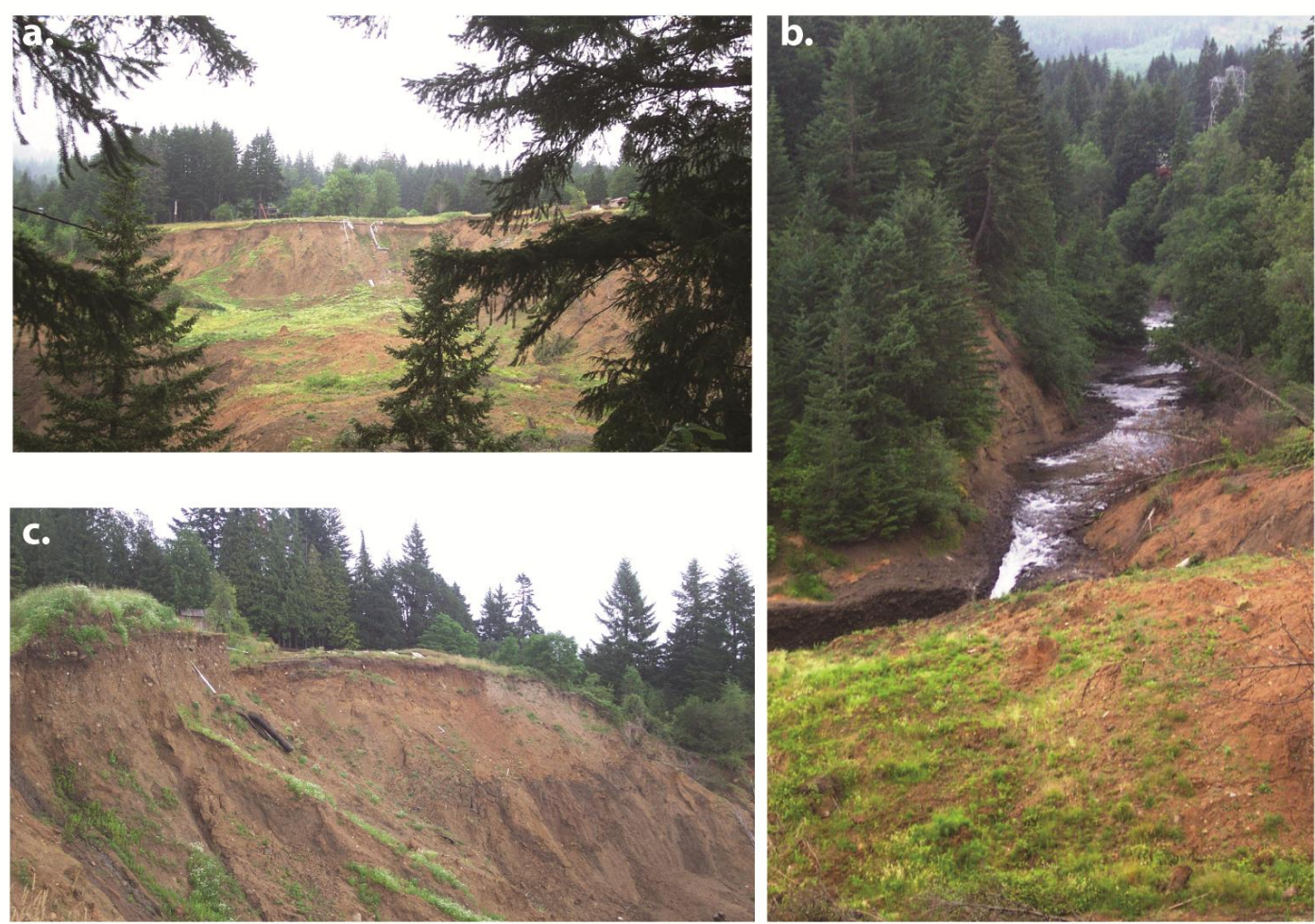

Figure 47. Lower Rock Creek area on the Stevenson Slide. a. Looking at an active scarp on the north side of Rock Creek. b. Photo of Rock Creek looking in a southerly direction at steep embankments. c. Closer look at the noth side of Rock Creek.

along a retreating scarp. The upper portion of the Stevenson Landslide appears to be stable because it is all vegetated with old growth forest, and there have been no reports of activity except for the Rock Creek area. It would probably take an extreme moisture event to get the flows on the Stevenson Landslide to get going again. It may be prudent on the part of the town of Stevenson to initiate a study in the area. 


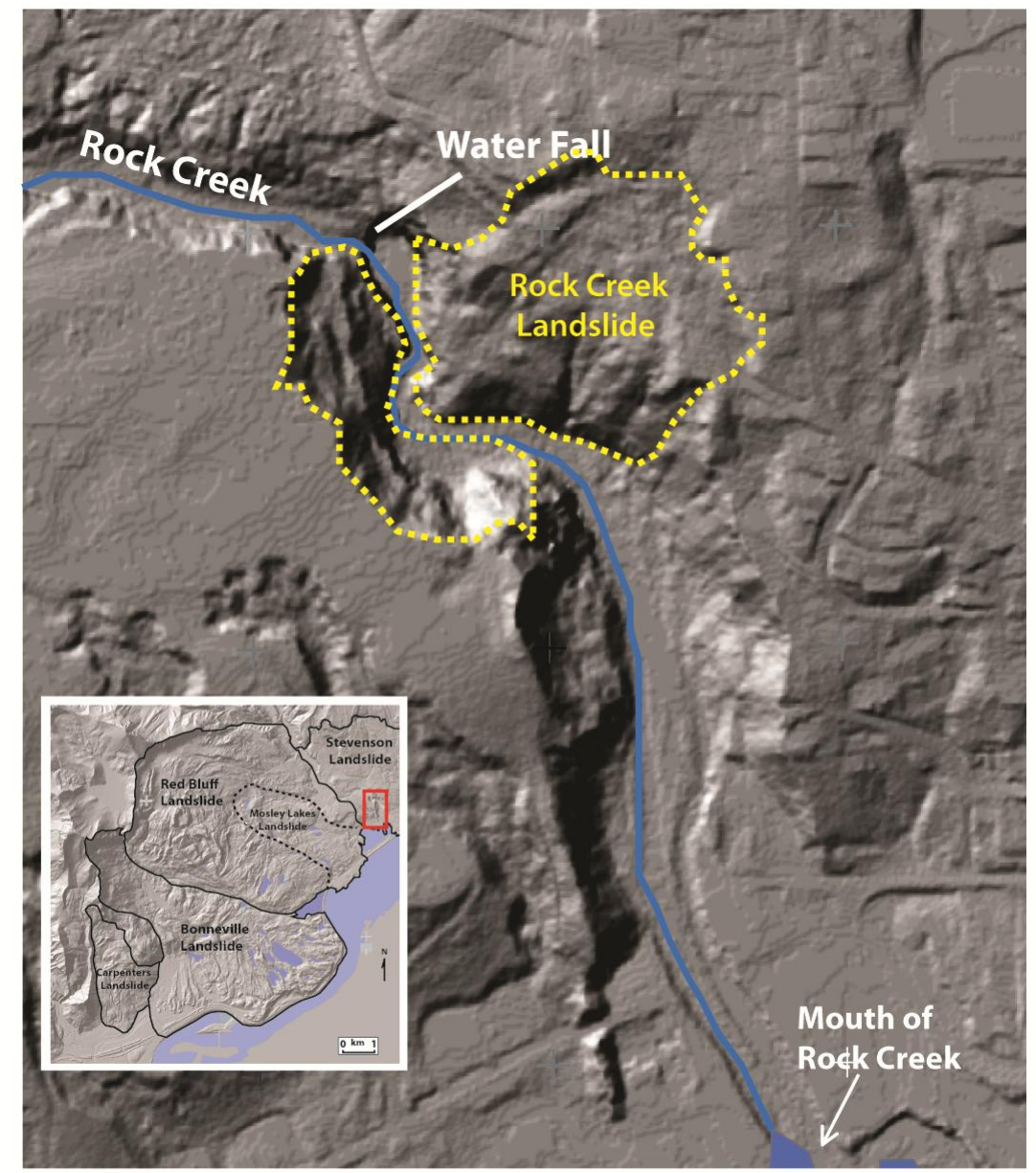

Figure 48. LiDAR image of the Rock Creek Landslide on the lower portion of Rock Creek on the Stevenson Slide. Inset included for location.

\subsection{Chronological Age Order of Landslides of the Cascade Landslide Complex}

Wise's (1961) dip slope, east and adjacent to the Red Bluff Landslide assisted in making a judgment on the relative ages of the landslides in the Greater Cascade Landslide Complex. I assert that the oldest landslide feature in the complex is the Stevenson dip slope, followed by the Red Bluff Landslide and finally to the youngest Bonneville Landslide. Two factors led me to this conclusion: overburden and landslide debris. 
The south trending Stevenson dip slope area is the oldest feature being an Ohanapecosh surface with no overburden, with Ohanapecosh sediment flows on the Stevenson Landslide. The youngest Bonneville Landslide has the greatest overburden as it is still saddled with a massive basalt headscarp. The landslide debris of the Bonneville Landslide in Figure 15 illustrates that basalt is a significant component of debris fragments. The Red Bluff Landslide has overburden and debris characteristics that are intermediary between the Bonneville and Stevenson Landslides. The main debris component of the Red Bluff Landslide is Eagle Creek sediments. The basalt capped Greenleaf Peak is considerable less than found on the Bonneville Landslide.

\subsection{Soils}

Four soils pits were excavated and analyzed for this study; two from the active upper lobe and two from the lower semi-fixed area and shown in Figure 20. All four pits yielded sand (S) textures (USDA) or a SW textural designation (USCS) of very low clay content and displayed characteristics of minimal development. All four pits were Inceptisols (Table 3) with A over Bw profiles and one pit with a A over Bw over Cox

Table 3. Soil pit location, profile, classification, relative age, and depth for each pit excavated on the Red Bluff Landslide.

\begin{tabular}{|c|c|c|c|c|c|}
\hline Soil Pit ID & $\begin{array}{c}\text { Surface on } \\
\text { Red Bluff Landslide }\end{array}$ & Soil Profile & $\begin{array}{c}\text { Soil } \\
\text { Classification }\end{array}$ & Relative Age (years) & Total Depth (cm) \\
\hline L1 & Lower & A/Bw & Inceptisol & $>1,600,<15,000$ & 66 \\
\hline L2 & Lower & A/Bw & Inceptisol & $>1,600,<15,000$ & 71 \\
\hline U3 & Upper Lobe & A/Bw & Inceptisol & $>1,600,<15,000$ & 56 \\
\hline U4 & Upper Lobe & A/Bw/Cox & Inceptisol & $>1,600,<15,000$ & 66 \\
\hline
\end{tabular}

profile. Based on the development of the soils, all four pits age from 1,600 to 15,000 
years old (Figure 49) (Burns et al., 2008), and support the idea that the upper lobe is less than or close to 15,000 years old and the same for the sediments below the lobe. The

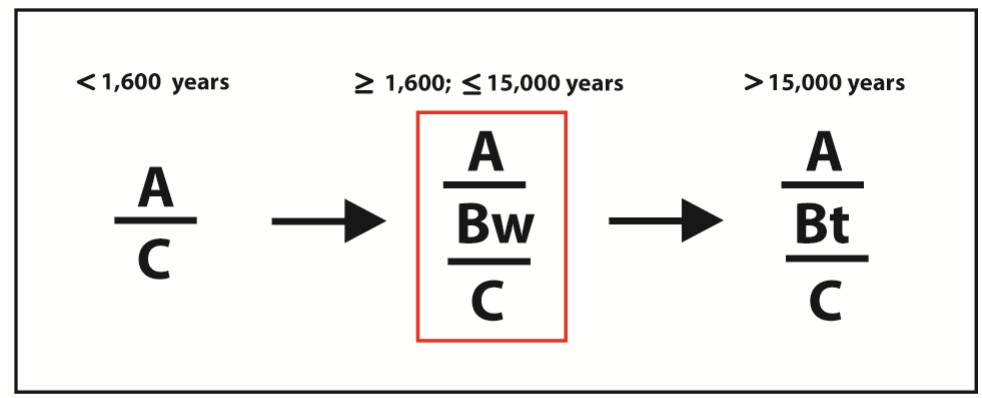

Figure 49. Soil chronosequence based on study of soils on Red Bluff Landslide (Based on Burns et al., 2008)

proposition that the lower semi-fixed portion of the slide is older than the overtaking lobe has not been satisfied and therefore inconclusive. This does not, however, negate my suggestion that there is an upper lobe overtaking a lower fixed portion. Photos of each of the four soil pits are shown in Figure 50 and in Figure 51.

The engineering properties of these soils were acquired through soil texture analysis (Birkeland, 1999) and are shown in Table 4. Summary of soil pit data is shown in Table 5. Texturally (USDA), all soils are field classified as sand (S). The textural classification results were also confirmed by the lab results of particle size analysis (Figure 52). The moisture content of the soils was relatively low, as were the plastic and liquid limits. The results for the soil density of each soil pit are as shown in Table 6. 


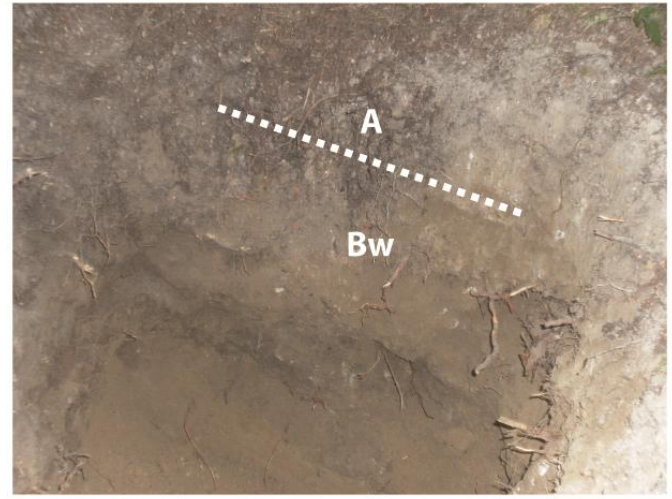

Soil pit L1

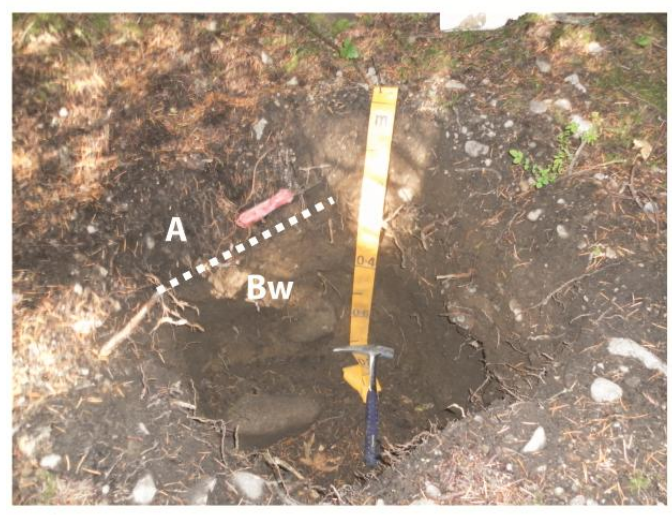

Soil pit L2

Figure 50. Soil pits in the lower portion of the Red Bluff Landslide. See Figure 20 for sites

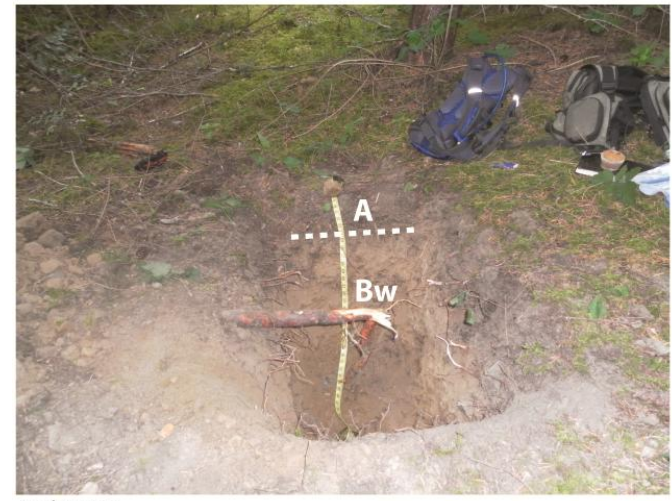

Soil pit U3

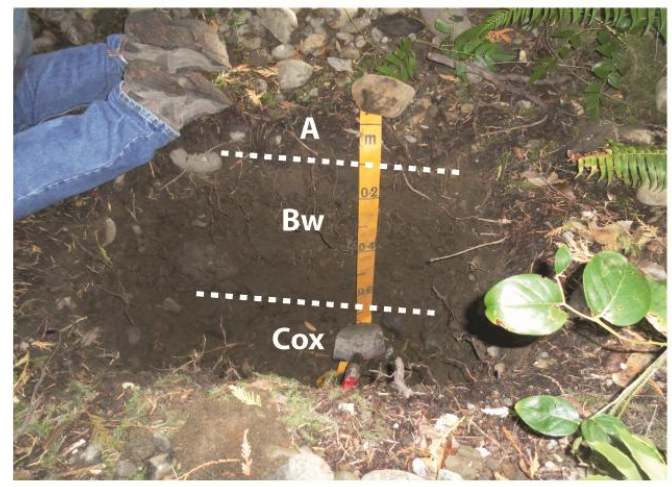

Soil pit U4

Figure 51. Soil pits in the upper portion of the Red Bluff Landslide. See Figure 20 for sites.

Table 4. Summary of grain size analysis for soils analyzed (using \#10 and \#230 for sand and silt boundaries).

\begin{tabular}{|c|c|c|c|c|}
\hline Soil Pit ID & \% Gravel & \% Sand & \% Fines & $\begin{array}{c}\text { Classification } \\
\text { (USDA) }\end{array}$ \\
\hline L1 & 16.6 & 82.6 & 0.8 & $\mathrm{~S}$ \\
\hline L2 & 27.1 & 70.6 & 2.3 & $\mathrm{~S}$ \\
\hline U3 & 25.9 & 71.4 & 2.7 & $\mathrm{~S}$ \\
\hline U4 & 41.7 & 57.4 & 0.9 & $\mathrm{~S}$ \\
\hline
\end{tabular}


Table 5. Summary of soil pit characteristics

\begin{tabular}{|c|c|c|c|c|c|c|c|c|c|c|}
\hline \multirow[t]{2}{*}{ Soil pit } & \multirow{2}{*}{$\begin{array}{l}\text { Elevation } \\
\text { (ft.) }\end{array}$} & \multicolumn{2}{|c|}{ Latitude (N) } & \multicolumn{2}{|c|}{ Longitude (W) } & \multirow{2}{*}{$\begin{array}{c}\text { Location } \\
\text { Coordinates }\end{array}$} & \multirow[t]{2}{*}{ Date } & \multirow{2}{*}{$\begin{array}{l}\text { Slope } \\
\text { (Degrees) }\end{array}$} & \multirow[t]{2}{*}{ Aspect } & \multirow[t]{2}{*}{ Vegetation } \\
\hline & & Degrees & Minutes & Degrees & \begin{tabular}{|l|} 
Minutes \\
\end{tabular} & & & & & \\
\hline L1 & 500 & 45 & 41.767 & -121 & 55.347 & $\begin{array}{l}0583895 \\
5060850 \\
\end{array}$ & $7 / 26 / 11$ & $2-4$ & $\mathrm{E}$ & $\begin{array}{l}\text { Douglas Fir, } \\
\text { underbrush }\end{array}$ \\
\hline L2 & 520 & 45 & 41.383 & -121 & 55.349 & $\begin{array}{l}0583914 \\
5060140\end{array}$ & 7/27/11 & $2-4$ & $S$ & $\begin{array}{l}\text { Douglas Fir } \\
\text { underbrush }\end{array}$ \\
\hline U3 & 690 & 45 & 46.767 & -121 & 55.347 & $\begin{array}{l}0583458 \\
5060400 \\
\end{array}$ & 7/28/11 & $2-4$ & SW & $\begin{array}{l}\text { Douglas Fir, } \\
\text { Cedar, underbrush }\end{array}$ \\
\hline U4 & 710 & 45 & 41.994 & -121 & 55.740 & $\begin{array}{l}0583370 \\
5061267 \\
\end{array}$ & 7/29/11 & $2-4$ & W & $\begin{array}{l}\text { Douglas Fir, } \\
\text { Cedar, underbrush }\end{array}$ \\
\hline
\end{tabular}

\begin{tabular}{|c|c|c|c|c|c|c|c|c|c|c|c|c|c|c|}
\hline \multirow{3}{*}{\begin{tabular}{|c|} 
Soil pit \\
L1 \\
\end{tabular}} & \multirow{2}{*}{\begin{tabular}{|c|}
$\begin{array}{c}\text { Depth } \\
(\mathrm{cm})\end{array}$ \\
$00-15$ \\
\end{tabular}} & \multirow{2}{*}{\begin{tabular}{c|} 
Horizon \\
$\mathrm{A}$
\end{tabular}} & \multirow[t]{2}{*}{ Color (Moist) } & \multirow{2}{*}{\begin{tabular}{|c|} 
Color (Dry) \\
Light Grayish Brown \\
\end{tabular}} & \multicolumn{3}{|c|}{ Structure } & \multirow[t]{2}{*}{ Gravel (\%) } & \multicolumn{3}{|c|}{ Consistance } & \multirow{2}{*}{$\begin{array}{c}\text { Clay Films } \\
\text { None }\end{array}$} & \multicolumn{2}{|c|}{ Boundaries } \\
\hline & & & & & & & & & & & & & & \\
\hline & $15-66+$ & $\mathrm{Bw}$ & 10 YR $4 / 3$ & 10 YR 4/2 & 2 & $f$ & sbk & 16.6 & so & $\mathrm{fr}$ & sh & None & g & $w$ \\
\hline \multirow{2}{*}{ L2 } & $00-10$ & A & & Light Brown & & & & & & & & None & & \\
\hline & $10-71+$ & Bw & 10 YR $3 / 2$ & 10 YR 4/2 & 2 & $f$ & sbk & 27.1 & so & fr & sh & None & $\mathrm{g}$ & w \\
\hline \multirow{2}{*}{ U3 } & $00-15$ & A & & Dark Brown & & & & & & & & None & & \\
\hline & $15-56+$ & $\mathrm{Bw}$ & 10 YR $3 / 4$ & 10 YR 5/4 & 2 & $f$ & sbk & 25.9 & so & $\mathrm{fr}$ & sh & None & g & w \\
\hline \multirow{3}{*}{ U4 } & $00-03$ & A & & Very Dark Brown & & & & & & & & None & & \\
\hline & $03-20$ & $\mathrm{Bw}$ & $10 \mathrm{YR} 3 / 2$ & 10 YR 4/2 & 2 & $f$ & sbk & 41.7 & so & $\mathrm{fr}$ & sh & None & $g$ & $w$ \\
\hline & $20-65+$ & Cox & & Very Dark Brown & & & & & & & & None & & \\
\hline
\end{tabular}

Table 6. Densities of soil in the soil pits

\begin{tabular}{|c|c|}
\hline Soil pit & Density $\mathbf{( g / \mathbf { c m } ^ { 3 } )}$ \\
\hline L1 & 1.40 \\
\hline L2 & 1.51 \\
\hline U3 & 1.44 \\
\hline U4 & 1.48 \\
\hline
\end{tabular}




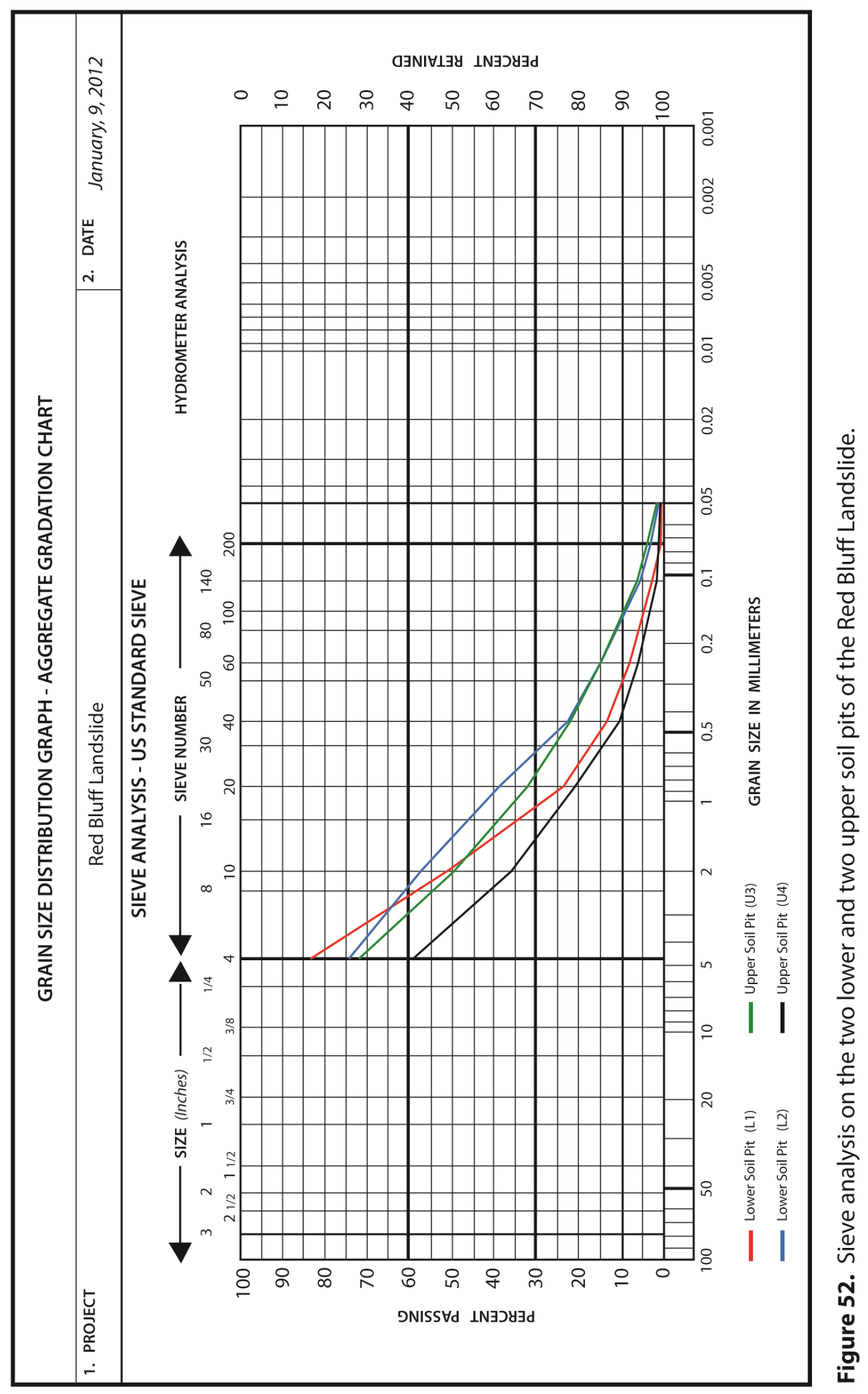




\subsection{Trees and Sag Ponds}

Other features that must be mentioned on the Red Bluff Landslide are the trees

(Figure 53) and the sag ponds.
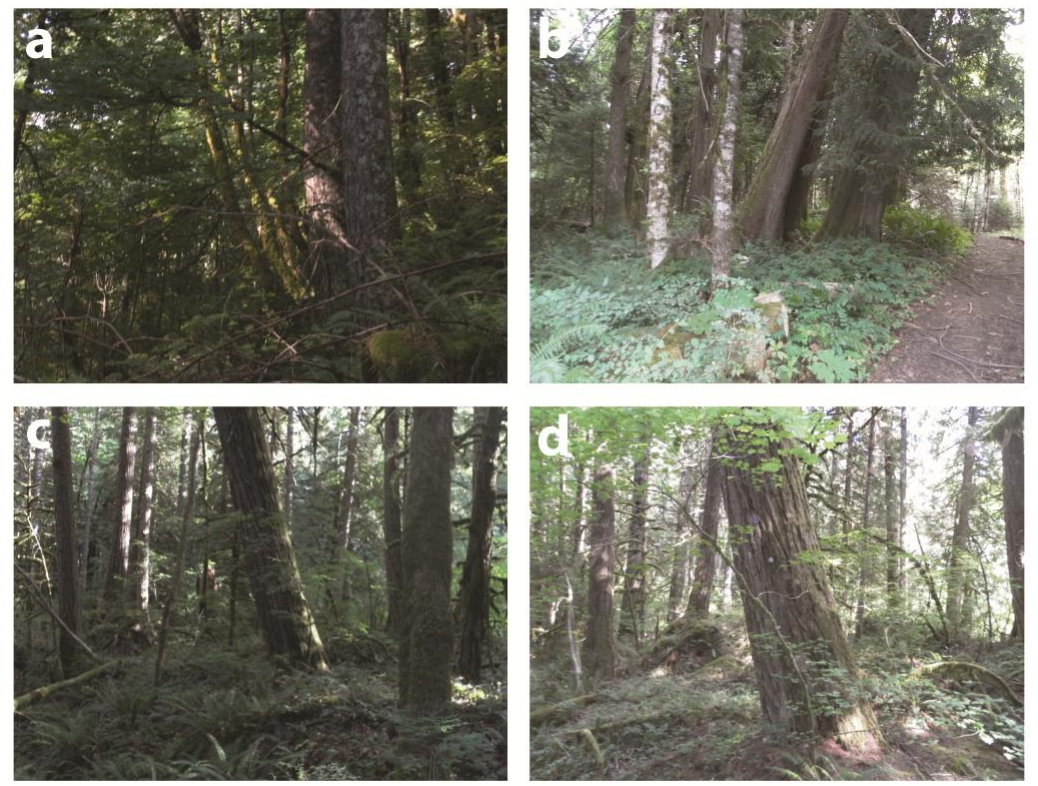

Figure 53. a. leaning trees on the southern flank of the scoria block seen in Figure 26 between events 2 and 3. b. clump of trees leaning to the NE close to headwall and where tension cracks are located. $\mathbf{c}$ and $\mathbf{d}$. trees leaning in different directions by Brush Lake

The re-activated upper lobe portion of the slide noticeably displays plenty of pistol-butted and leaning trees with heavier concentrations around the downslope perimeter (Figure 53). All lean or are pistol- butted in different directions not showing a preferential direction to establish overall direction of movement or to be valuable information with respect to time of movement since the slide has been active for thousands of years.

The sag ponds (Figure 54) are an interesting feature not discussed in this thesis because they did not contribute to the study. I did however notice the largest of the 
Mosley Lakes and Crescent Lake are all longer than they are wide and are in areas where compressional forces are present.
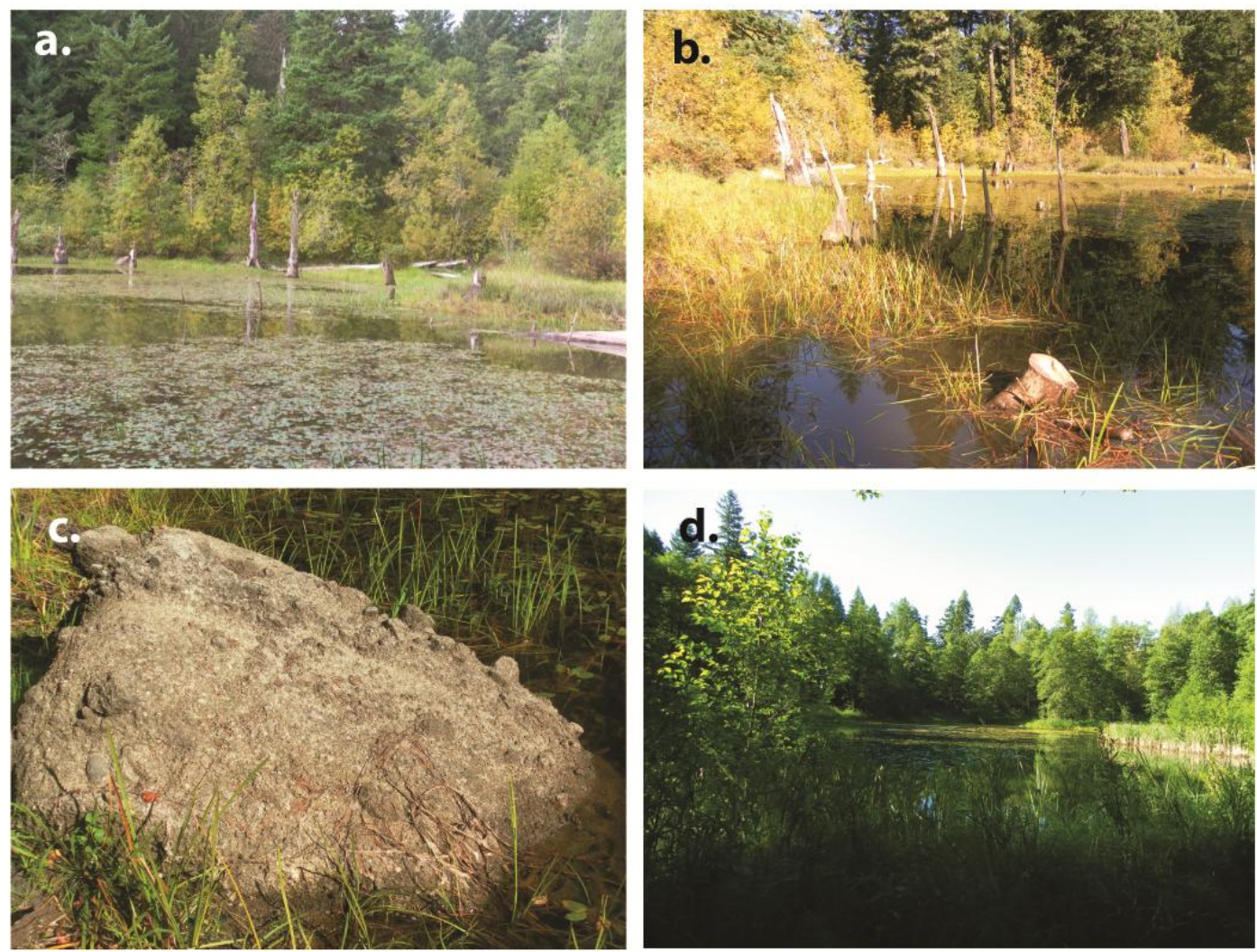

Figure 54. Some of the sag ponds on the Red Bluff Landslide. $\mathbf{a}$. and $\mathbf{b}$. a couple of the smaller Mosley Lakes. c. An Eagle Creek boulder on one of the Mosley Lakes. d. Photo of Brush Lake 


\section{Chapter 5.0 Summary/Conclusions}

The Red Bluff Landslide, nestled in between the Bonneville Landslide and the Stevenson Landslide, covers an area of $18.67 \mathrm{~km}^{2}$ of the $43.0 \mathrm{~km}^{2}$ Greater Cascade Landslide Complex and is located where the Columbia River cuts through the central uplifted core of the Cascade Mountains. The region is typified by Grande Ronde Basalts overlying older incompetent Eagle Creek Formation and the older Ohanapecosh type volcaniclastic rocks and sediments allowing large landslides to move towards the Columbia River on southward dipping slopes averaging 7 degrees (Palmer 1977).

Two units characterize the Red Bluff Landslide: An upper lobe moving across and spreading over a lower semi-fixed portion of the slide. The Red Bluff Landslide can be loosely classified as a deep seated translational slide, creeping in a southerly direction overlapping the Bonneville Landslide, and spreading laterally in an eastwardly direction over the lower portion of the slide. The lower portion is covered by a relatively thin veneer of Eagle Creek landslide sediments most likely underlain by Ohanapecosh type rocks/sediments and/or parts of in-place Eagle Creek Formation.

The Red Bluff Landslide likely had its origin in the Pleistocene, with the Missoula Floods (18,000 - 15,000 years ago) accelerating the erosional process. The maximum flood level from the largest floods probably reached levels in excess of the 250 meters a.s.I. (820 feet). It was during this time that the Red Bluff Landslide was probably washed out and re-accumulating mass, forming an upper lobe.

The movement of the Red Bluff Landslide before the Missoula Floods is unknown but each flood event during Missoula Flood time probably brought debris down covering 
the slide with a thin layer of Eagle Creek sediment debris. The last Missoula Flood probably eroded and "smoothed" the lower surfaces of the landslide. Since that time, the upper lobe has been actively spreading across the smoothed lower surface.

The debris, eroding from the main headscarp of Red Bluff Landslide, is composed mostly of andesitic basalt from the west headwall volcanoes and Eagle Creek Formation sediments from the north head wall. This is the source material for the upper lobe. The debris, accumulated off the headwall, presently represents over 15,000 years of accumulation forming an active upper lobe covering an area of $8.6 \mathrm{~km}^{2}$ of the $18.76 \mathrm{~km}^{2}$ area taken up by the Red Bluff Landslide. This upper lobe is the active portion of the slide. Failure of the Red Bluff Landslide area is progressive, occurring in increments, having begun at the Columbia River and progressing headward. It continues to undergo deformation from water-saturated layers during times of heavy precipitation.

With respect to the history of the Red Bluff Landslide, the earliest most significant event initiated with the formation of the Red Bluff Volcanoes approximately 146,000 years ago (Evarts, 2010, personal communication). Shortly afterwards, the volcanoes started to undergo a series of collapses. I have identified five collapse events, each identifiable relative to the location of the Red Bluff Volcanoes neck. Two of these events are likely pre-Missoula Flood and three are probably post Missoula Flood (Figure 28).

Not only is the Red Bluff Landslide composed of andesitic basalt from the volcanoes, it also is a matrix of Eagle Creek Formation sediments that have sifted through the landslide debris. Movement of the upper active lobe is not steady. It moves 
only when there is enough water in the system for movement. When it does move, it moves in a differential manner. Different parts of the active upper lobe move at different places at different times. It is moving at a rate close to $25 \mathrm{~cm} / \mathrm{yr}$ in a southerly direction, overlapping the Bonneville Landslide, and spreading laterally close to $6 \mathrm{~cm} / \mathrm{yr}$, in an eastwardly direction.

The last relatively big event that occurred on the Red Bluff Landslide is what we refer to as the Old Greenleaf Basin Rock Avalanche (Figure 37, 38). It was a failure event estimated to have occurred 100 to 150 years ago based on vegetation cover. It was present on the slide in 1934 based on an aerial photo provided by the Corps of Engineers (Figure 39). It has an area of $161,250 \mathrm{~m}^{2}$, and a volume of 1.9 million $\mathrm{m}^{3}$. It has a length of $750 \mathrm{~m}$, an average width of $215 \mathrm{~m}$ and is the surface upon which the January 2008 Greenleaf Basin Rock Avalanche flowed.

The recent January 2008 Greenleaf Basin Rock Avalanche, on the southern portion of the Red Bluff Landslide, was the last event to have deposited a considerable amount of material onto the Red Bluff Landslide at one time. It failed in a southerly direction with a runout length of $730 \mathrm{~m}$, a volume of $375,000 \mathrm{~m}^{3}$, an average width of $140 \mathrm{~m}$, and covered an area of $99,500 \mathrm{~m}^{2}$. The average surface depth of the rockslide is $1.22 \mathrm{~m}$ with some deposits up to $10 \mathrm{~m}$ in depth and the scarp length is $116 \mathrm{~m}$. It contributed approximately $0.058 \%$ of the total volume and $0.01 \%$ of the surface area to the active portion of the Red Bluff Landslide. The failure surface of the rockfall on the western headwall is suspected as perched water from a spring fed part of the lower Eagle Creek Formation. A case was made that the Greenleaf Basin Rockfall Avalanche 
was insignificant in movement of the active part of the Red Bluff Landslide winter of 2007-2008, based on it being only $0.058 \%$ of the total reactivated volume, and the InSAR images, which indicated different parts of the slide move at different times. The Greenleaf Basin Rock Avalanche contributed to the load on the Red Bluff Landslide but likely did not cause the reactivation of the Red Bluff Landslide that winter of 2007-2008.

Wise's Mosley Lakes Landslide is non-existent based upon analysis of imagery, profiles created from tools in ArcGIS and field truthing. It didn't have a headscarp and was mapped flowing almost perpendicular to dip.

Whereas the Red Bluff Landslide is active and the Bonneville Landslide recently failed catastrophically, the Stevenson Slide is relatively stable having lost all of its overburden from former sliding. The Stevenson Slide has, however, locally reactivated in the very lower portions along Rock Creek, where it cuts through in-place Eagle Creek Formation and into the Ohanapecosh Formation. I propose increasing the size of the complex area by $7.5 \mathrm{~km}^{2}$, by adding the Stevenson Landslide. With this, I have renamed the Cascade Landslide Complex to the "Greater Cascade Landslide Complex" making it a total of $43 \mathrm{~km}^{2}$ (Figure 54). Not including the Stevenson Slide into the complex would be incomprehensible because it shares a history, it is connected, related in a process, and has the same dip slope. Although not conclusive, it is coincidental that the headscarps along the northern boundary of the Stevenson Slide match Missoula Flood heights and the lineation of those scarps line up with the trajectory of the largest Missoula Flood off the Columbia River. 


\section{The Greater Cascade Landslide Complex}

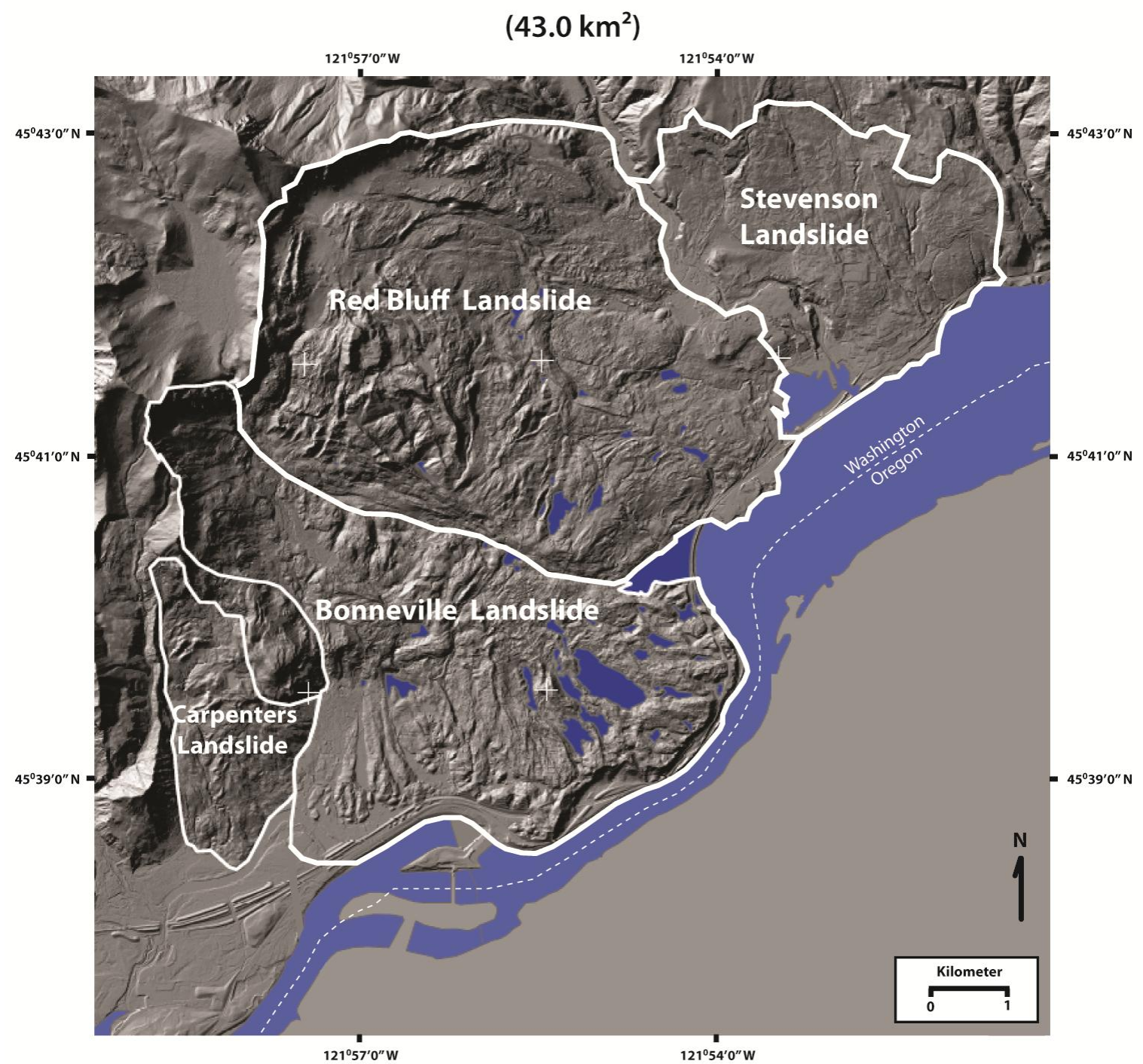

Figure 55. The Greater Cascade Landslide Complex and members: The Carpenters Landslide, Bonneville Landslide, Red Bluff Landslide and the Stevenson Landslide. 


\section{Chapter 6.0 - Future Work}

The groundwork in this thesis has been laid for the Red Bluff Landslide, but there is yet future work to do. With respect to infrastructure, I suggest the town of Stevenson be aware of the work being done by the Cascade Volcano Observatory, specifically the InSAR data yet to be released. Over time, the InSAR data together with rain data should help define the creep and the minimum threshold of precipitation for movement. Future work should also include a characterization of the Carpenters Landslide and a possible small slide to the immediate northwest of it. A study of the Skamania Landslide, immediately to the west of the Cascade Landslide Complex is another unknown. It has hummocky hills of broken and deformed highly permeable Columbia River Basalts on top of Eagle Creek and/or Ohanapecosh Formations. The Washougal Landslide, west of the Skamania Landslide is another slide that lacks detailed information. All of these slides including the Cascade Landslide Complex involve the same geological units, and failure is thought to occur in similar units. A study of the Washougal and Skamania slides may also provide further insight to the Cascade Landslide Complex and the region. Cosmogenic isotope dating is another possibility for future work on the Red Bluff Landslide for a better handle on the ages of the five collapse events of the Red Bluff Volcano on the upper lobe. 


\section{References}

Allen, J.E., Burns, M., and Burns, S.F., 2009, Cataclysms on the Columbia: The Great Missoula Floods, Ooligan Press, Portland, Oregon. p. $153-159$.

Atwater, B.F., 1984, Number, frequency, and relative magnitude of last-glacial floods from Pleistocene Lake Missoula, Montana: evidence from the Sanpoil River Valley, northeastern Washington, Eos (American Geophysical Union Transactions), v. 65, no. 45, p. 893.

Beeson, M.H., and Tolan, T.L., 1984, Intracanyon flows of the Columbia River Basalt Group in the lower Columbia River Gorge and their relationship to the Troutdale Formation: Geological Society of America Bulletin, v. 95, no. 4, p. 463-477.

Bela, James L., compiler, 1982, Geologic and neotectonic evaluation of north-central Oregon - The Dalles $1^{0} \times 2^{0}$ Quadrangle: Oregon Department of Geology and Mineral Industries Geological Map Series GMS-27.

Benito, G. and O'Connor, J.E., 2003, Number and size of last-glacial Missoula floods in the Columbia River Valley between the Pasco Basin, Washington, and Portland, Oregon: Geological Society of America Bulletin, v. 115, no. 5, p. 624-638.

Birkeland, P., 1999, Soils and Geomorphology, Oxford University Press, Inc., pp. 171 229.

Bjornstad, B.N., and Fecht, K.R., 1989, Pre-Wisconsin glacial-outburst floods: pedogenic and paleomagnetic evidence from the Pasco Basin and adjacent channeled scabland", Geological Society of America, Abstract with Programs, v. 21, no. 5, p. 58.

Bockheim, J.G., Marshall, J.G., and Kelsey, H.M., 1996, Soil-forming processes and rates on uplifted marine terraces in southwestern Oregon, USA: Geoderma, v. 73, pp. 39-62.

Burns, S.F., 2008, personal communication, Department of Geology, Portland State University, Portland, Oregon.

Burns, S.F., James, D., Cordero, D., Lawes, J., 2008, Quaternary History of Missoula Floods in Oregon Based Soils, XVI INQUA Congress, Reno, Nevada, Abstracts with Program, p. 203.

Burns, S.F., 1998, "Landslides in the Portland area resulting from the storm of February, 1996," in S.F. Burns, editor, Environmental, Groundwater and Engineering Geology: Applications from Oregon, Star Publishing, Belmont, California, pp 303-315. 
Cornforth, D.H., 2005, Landslides in Practice: Investigation, Analysis, and Remedial/Preventative Options in Soils, Wiley, Hoboken, New Jersey.

DNR, 2007, LiDAR DEM of Skamania County, Washington Department of Natural Resources, Olympia Washington, www.dnr.wa.gov

Evarts, R., 2009-11, Personal communication, U.S. Geological Survey, 345 Middle Field Dr., Menlo Park, California. 94025

Gee, G.W. and Bauder, J.W., 1986, Methods of Soil Analysis, Part 1, in Physical and Mineralogical Methods - Agronomy Monographs, no. 9, pp. 383-410

Golder Associates Inc., 2009, Williams-Northwest pipeline discussion on the Blue Ridge mainline deviation (Willard Loop) around the Columbia River Gorge landslides - report submitted to Williams Northwest Pipeline; investigators D.O. West, A.Q. Kammereck: Golder Associates Inc. Job No. 083-93045-01.500.501, 16 p.

Haagen, Edward, 1990, Soil Survey of Skamania County Area, Washington. Soil Conservation Service, National Printing Office, Washington, D.C., 430 p.

Holdredge, C.P., 1937, Final geologic report on the Bonneville Project: U.S. Army Engineer District [Portland, Oregon], $1 \mathrm{v}$.

Korosec, M.A. and Berri, D.A., 1983, Geological and Geothermal Investigation of the Lower Wind River Valley, Southwestern Washington Cascade Range. Washington Department of Natural Resources, Division of Geology and Earth Resources, Olympia, Washington. Open File Report 83-5, p.9

Korosec, M.A., 1987, Geologic Map of the Hood River Quadrangle, Washington and Oregon, Washington Division of Geology and Earth Resources, Open File Report 87-6.

Lawrence, D.B., 1937, Drowned forests of the Columbia River Gorge: Geological Society of the Oregon Country Geological News Letter, v. 3, no. 8, p. 78-83.

Lawrence, D.B. and Lawrence, E.G., 1958, Bridge of the Gods legend - its origin, history, and dating: Mazama, v. 40, no. 13, p. 33-41.

Lu, Z., 2011, personal communication, U.S. Geological Survey, Cascade Volcano Observatory (CVO), Vancouver, Washington.

Medley, Erica, 2012, "Ancient Cataclysmic Floods in the Pacific Northwest: Ancestors to the Missoula Floods", MS thesis, Department of Geology, Portland State University, 130 pp. 
Moulton, G.E., 1991, The Definitive Journals of Lewis and Clark; From the Pacific to the Rockies; Volume 7 of the Nebraska Edition: Lincoln, Nebraska, University of Nebraska Press, $383 \mathrm{p}$.

O'Connor, J.E., and Burns, S.F., 2009, Cataclysms and controversy - aspects of the geomorphology of the Columbia River Gorge in O'Connor, J.E., Dorsey, R.J., and Madin, I.P., editors, Volcanoes to Vineyards: Geologic Field Trips through the Dynamic Landscape of the Pacific Northwest: The Geological Society of America, Inc., Boulder, Colorado, Field Guide 15, p. 237-251.

O'Connor, J.E., 2011, The Bridge of the Gods: Folklore, Forests, and Floods. United States Geological Survey, presentation of November 29, 2011 at McMenamins, Troutdale.

Palmer, Leonard, 1977, Large landslides of the Columbia River Gorge, Oregon and Washington. Geological Society of America, Reviews in Engineering Geology, Volume III, p. $69-82$.

Pierson, T.C., and Lu, Z., 2009, InSar detection of renewed movement of a large ancient landslide in the Columbia River Gorge, Washington, Geological Society of America Abstract with Programs, Portland Annual Meeting 2009, Vol.41, No. 7: p. 497 http://gsa.confex.com/gsa/2009AM/finalprogram/abstract_162891.htm

Schaetzl, R.J. and Anderson, 2005 Soils: Genesis and Geomorphology: Cambridge University Press, Cambridge, United Kingdom, 8p.

Soil Survey Staff, 2002, Field Book for Describing and Sampling Soils: National Soil Survey Center, USDA, Washington, D.C.

U.S. Army Corps of Engineers, 1976, $2^{\text {nd }}$ powerhouse railroad tunnel: U.S. Army Corps Engineers, Portland District, Design Memo. No. 7, Supplement No. 4, May., 24 p.

U.S. Army Corps of Engineers, 1994, Foundation Report, Bonneville Second Powerhouse: U.S. Army Corps Engineers, Portland District

Waitt, R.B., 1980, About forty last-glacial Lake Missoula jökulhlaups through southern Washington: Jour.Geology, v.88, p.653-679

Wang, Yumei, Hofmeister, R.J., McConnell, Vickie, Burns, S.F., Pringle, P.T., 2002, Columbia River Gorge landslides - Field trip guidebook for the National Academies:[Privately published by the authors], 22p. 
Waters, A. C., 1973, The Columbia River Gorge - Basalt stratigraphy, ancient lava dams and landslide dams. In Beaulieu, J.D., Geologic Field Trips in Northern Oregon and Southern Washington: Oregon Department of Geology and Mineral Industries Bulletin 77, p. 133-162.

Wise, W. S., 1970, Cenozoic volcanism in the Cascade Mountains of Southern Washington: Washington State Dept. Nat. Resources Bull. 60, p. 1 - 44

Wise, W. S., 1961, The Geology of the Wind River area, Washington, and the Stability Relations of Celadonite [Ph.D. dissert.]: John Hopkins University, p.191 - 195

WRCC (Western Region Climate Center), 2010, Monthly Total Precipitation, Bonneville Dam, Station \# 350897, www.wrcc.dri.edu, Reno. NV. 